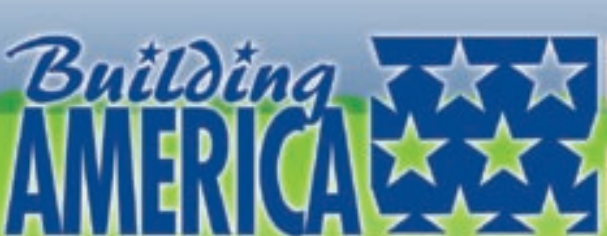

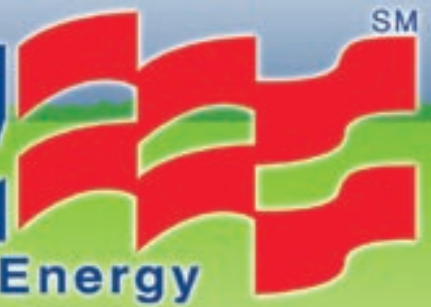

Research that Works

May 2005 • NREL/TP-550-37731

\title{
The Hathaway "Solar Patriot" House: A Case Study in Efficiency and Renewable Energy
}

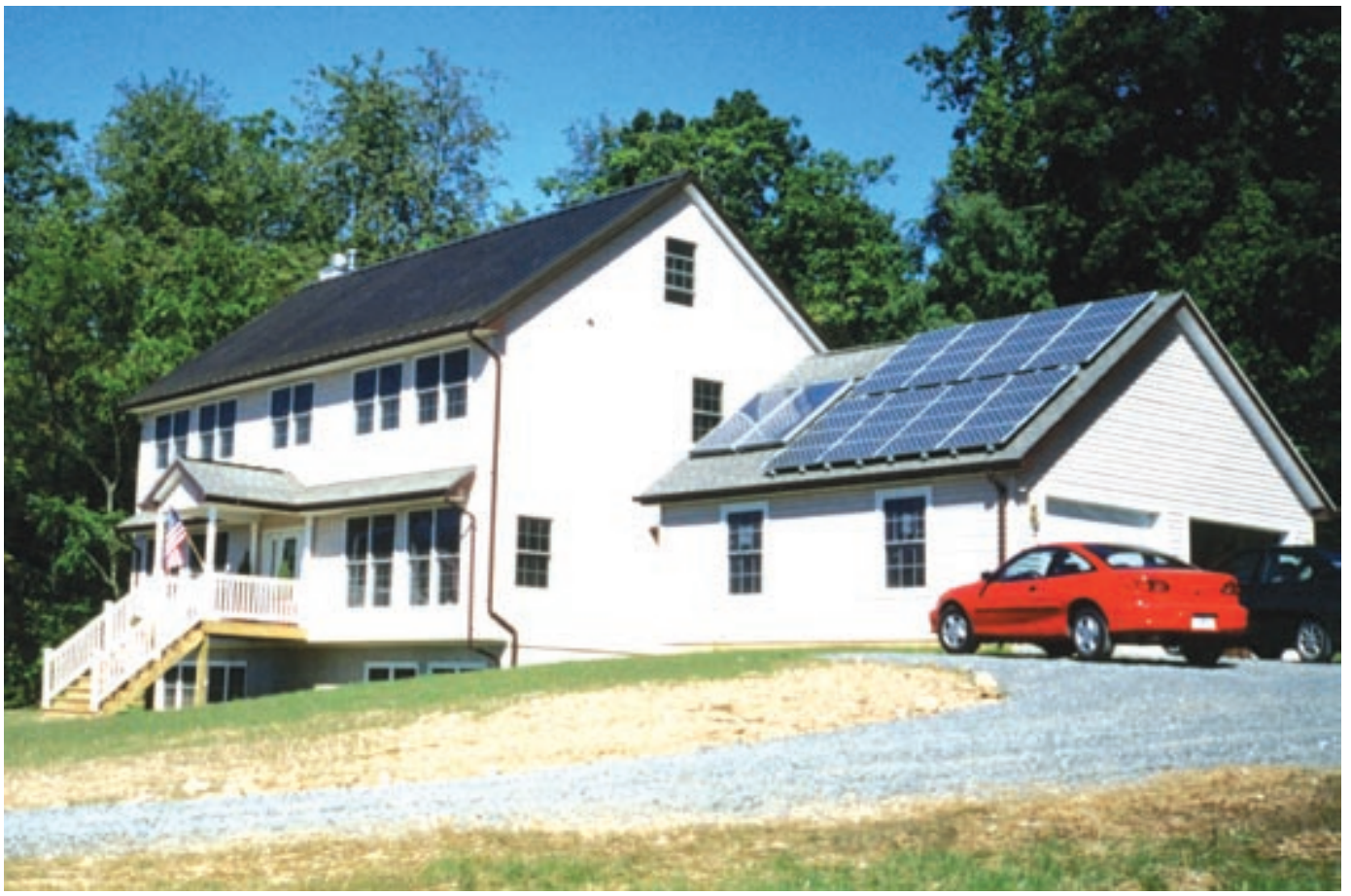

Paul Norton

National Renewable Energy Laboratory

Ed Hancock and Greg Barker Mountain Energy Partnership

Paul Reeves

Partnership for Resource Conservation 


\section{The Hathaway "Solar Patriot" House: A Case Study in Efficiency and Renewable Energy}

Paul Norton

National Renewable Energy Laboratory

Ed Hancock and Greg Barker

Mountain Energy Partnership

\section{Paul Reeves}

Partnership for Resource Conservation

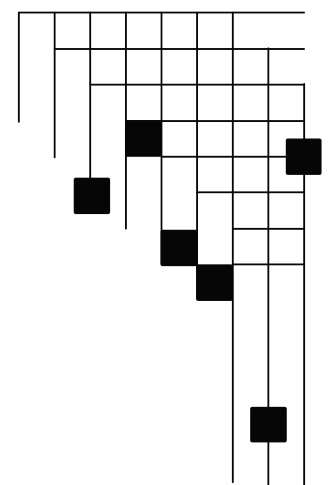

Prepared under Task No. BET5.8004

National Renewable Energy Laboratory

1617 Cole Boulevard, Golden, Colorado 80401-3393

303-275-3000 • www.nrel.gov 


\section{NOTICE}

This report was prepared as an account of work sponsored by an agency of the United States government. Neither the United States government nor any agency thereof, nor any of their employees, makes any warranty, express or implied, or assumes any legal liability or responsibility for the accuracy, completeness, or usefulness of any information, apparatus, product, or process disclosed, or represents that its use would not infringe privately owned rights. Reference herein to any specific commercial product, process, or service by trade name, trademark, manufacturer, or otherwise does not necessarily constitute or imply its endorsement, recommendation, or favoring by the United States government or any agency thereof. The views and opinions of authors expressed herein do not necessarily state or reflect those of the United States government or any agency thereof.

Available electronically at http://www.osti.gov/bridge

Available for a processing fee to U.S. Department of Energy and its contractors, in paper, from:

U.S. Department of Energy

Office of Scientific and Technical Information

P.O. Box 62

Oak Ridge, TN 37831-0062

phone: 865.576 .8401

fax: 865.576 .5728

email: mailto:reports@adonis.osti.gov

Available for sale to the public, in paper, from:

U.S. Department of Commerce

National Technical Information Service

5285 Port Royal Road

Springfield, VA 22161

phone: 800.553.6847

fax: 703.605.6900

email: orders@ntis.fedworld.gov

online ordering: http://www.ntis.gov/ordering.htm 


\section{Table of Contents}

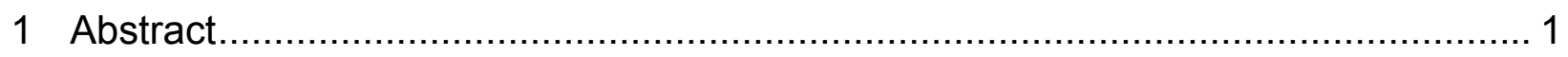

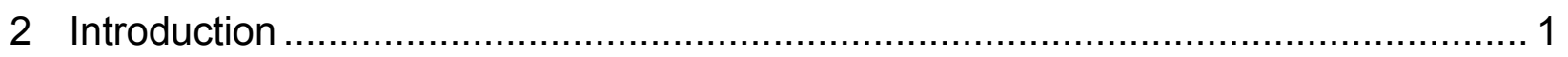

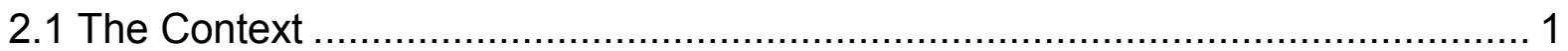

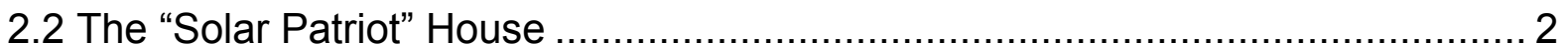

2.3 The Hathaway House Specifications …..................................................... 3

2.4 Study Objectives and Overview ............................................................. 7

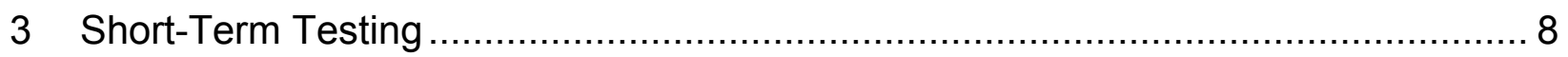

3.1 Air Exchange Characteristics............................................................. 9

3.2 Heat Pump Coefficient of Performance (COP) ….................................. 15

3.2.1 Heating Mode COP ..................................................................... 15

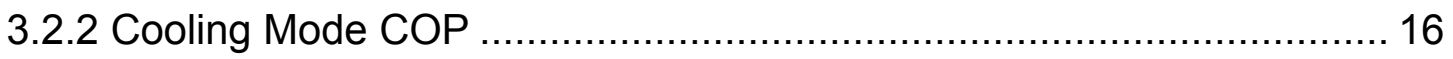

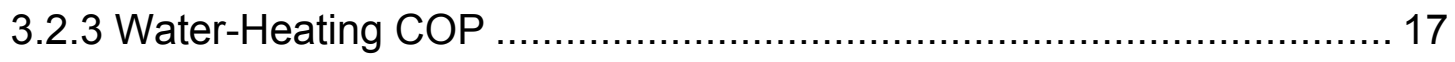

3.3 Other Short-Term Measurements and Observations ................................. 21

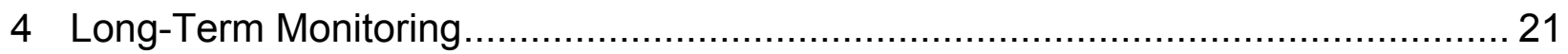

4.1 Monitoring System and Data being Collected....................................... 21

4.2 Results from the Entire Monitoring Period .......................................... 24

4.3 Results from the Calendar Year 2002 and 2003 ................................... 29

4.4 Average Hourly Profiles .................................................................... 30

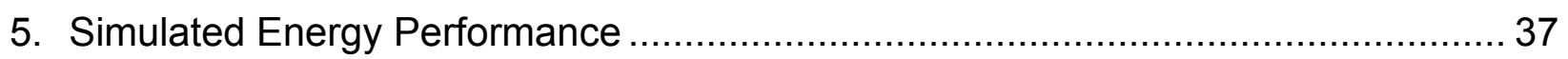

5.1 Improving Accuracy: Modeling Specific Systems......................................... 38

5.2 Building Confidence: Comparing Monitored Data and the Simulation Results .. 38

5.3 Putting Performance in Context: Simulation Results..................................... 41

5.4 What if . . . Investigating Possible Improvements.......................................... 43

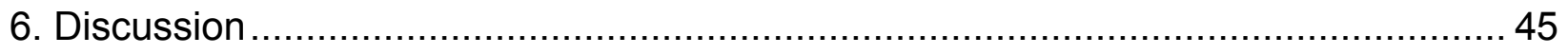

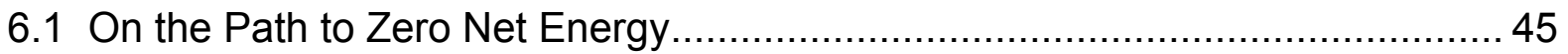

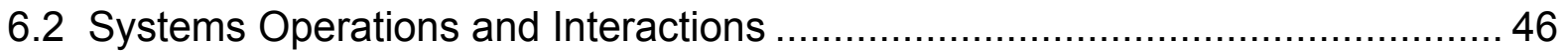

6.3 Modeling and Monitoring Approach ....................................................... 46

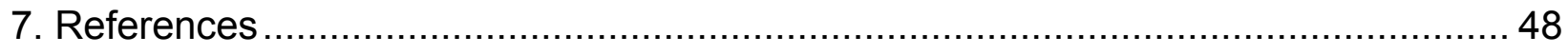




\section{List of Figures}

Figure 1. The "Solar Patriot" home on the National Mall in Washington, D.C............... 2

Figure 2. The Solar Patriot house at its permanent location in Purcellville, Virginia (photo by Ed Hancock) ....................................................................... 3

Figure 3. Floor plans for the first and second floors of the Hathway House ................. 5

Figure 4. Duck supply trunk entering attic and continuing to trunk above the framing for the finished space.

Figure 5. Supply register for attic space (top photo) and supply duct descending to ceiling register for second floor (bottom photo) ……................................ 6

Figure 6. Alden Hathaway and blown-in cellulose insulation in attic ........................... 7

Figure 7. Blower door installed in the Hathaway House .......................................... 8

Figure 8. Comparison of tracer gas $\mathrm{ACH}$ measurements to $\mathrm{ACH}$ modeled using blower door ELA measurement.................................................................. 14

Figure 9. Space-heating COP determined from monitored data (fan power not

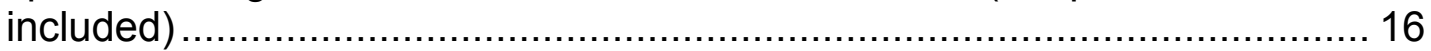

Figure 10. Space-cooling COP determined from monitored data (fan power not

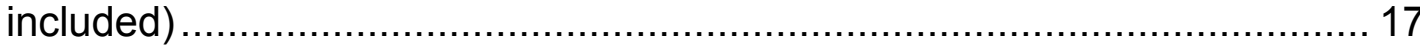

Figure 11. Coefficient of performance (COP) of heat pump for water heating.............. 18

Figure 12. Domestic hot-water (DHW) COP determined from monitored data............. 19

Figure 13. Total energy consumption by end use for the entire monitoring period -

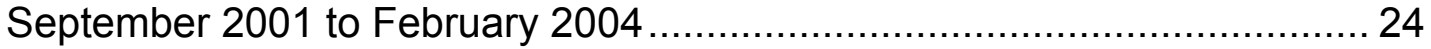

Figure 14. Monthly energy consumption by end use …........................................... 25

Figure 15. Monthly electrical energy (AC) produced by the PV system....................... 26

Figure 16. Monthly net electrical energy bought.................................................. 27

Figure 17. Monthly electrical energy (DC) produced by each of the three PV arrays and average outdoor temperature (west and east are arrays on the roof of the home)....

Figure 18. Energy produced by the PV system and net energy bought from the grid for 2002 and 2003

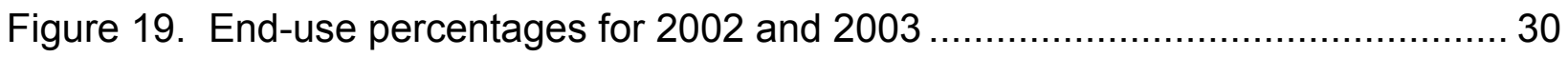

Figure 20. Outdoor temperature average hourly profile......................................... 31

Figure 21. First-floor indoor temperature average hourly profile ............................. 31

Figure 22. Irradiance in the plane of the collector average hourly profile .................... 32

Figure 23. DC power from the PV system average hourly profile ............................. 32

Figure 24. Total power use average hourly profile .................................................... 33 
Figure 25. Net power bought from the grid average hourly profile ............................. 33

Figure 26. Power used for space conditioning average hourly profile ......................... 34

Figure 27. Heat-pump power used for water heating average hourly profile ................. 34

Figure 28. Hot water draw average hourly profile ...................................................... 35

Figure 29. Clothes washer power use average hourly profile.................................... 35

Figure 30. Clothes dryer power use average hourly profile ..................................... 36

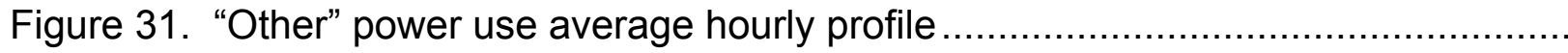

Figure 32. DOE2 model of the Hathaway House, the dark area simulates the shading of the home by the garage and breezeway roof

Figure 33. Monitored data vs. simulation results for total energy using Building America assumptions and TMY2 data...................................... 39

Figure 34. Monitored data vs. the adjust model results, whole-building energy use .... 40

Figure 35. Energy use by end-use category, beyond the Hathaway prototype 44

\section{List of Tables}

Table 1. Summary of Specifications for the Hathaway House .................................... 4

Table 2. Results of Blower Door and Duct Testing ............................................... 10

Table 3. Register and Exhaust Fan Flow Results .............................................. 12

Table 4 Flow-Plate Measurements of the Total Air-Flow Rate at the Air-Handler ..... 13

Table 5. Energy Balance for Domestic Hot Water (DHW) System ........................... 20

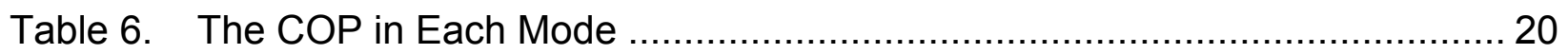

Table 7. Data Monitored at the Hathaway House …............................................. 23

Table 8. Summary of End-Use Site Energy...................................................... 42

Table 9. Summary of End-Use Source Energy and Savings ................................. 42

Table 10. Energy Savings of Energy Efficiency Measures .................................... 42

Table 11. Energy Reduction by End-Use Compared to the Building America Benchmark 


\section{List of Terms}

$\begin{array}{ll}\text { AC } & \text { alternating current } \\ \text { ACH } & \text { air changes per hour } \\ \text { ASES } & \text { America Solar Energy Society } \\ \text { BEopt } & \text { Building Energy Optimization simulation model } \\ \text { BESTEST } & \text { simulation software } \\ \text { cfm } & \text { cubic feet per minute } \\ \text { COP } & \text { coefficient of performance } \\ \text { DC } & \text { direct current } \\ \text { DHW } & \text { domestic hot water } \\ \text { DOE } & \text { U.S. Department of Energy } \\ \text { DOE2 } & \text { simulation software } \\ \text { EF } & \text { Energy Factor } \\ \text { ELA } & \text { equivalent leakage area } \\ \text { EPA ENERGY STAR } & \text { Environmental Protection Agency Energy STAR program } \\ \text { HVAC } & \text { heating, ventilation, and air conditioning } \\ \text { HP } & \text { heat pump } \\ \text { HSPF } & \text { Heating Seasonal Performance Factor } \\ \text { IR } & \text { infrared } \\ \text { LBNL } & \text { Lawrence Berkeley National Laboratory } \\ \text { MEC } & \text { 1995 Model Energy Code } \\ \text { NREL } & \text { National Renewable Energy Laboratory } \\ \text { Pa } & \text { Pascal } \\ \text { PV } & \text { photovoltaic } \\ \text { SEER } & \text { Seasonal Energy Efficiency Rating } \\ \text { SF6 } & \text { sulfur hexafluoride } \\ \text { TMY } & \text { typical meteorological year } \\ \text { TRNSYS } & \text { TRaNsient SYstem Simulation program } \\ \text { UA } & \text { overall heat-transfer coefficient (U) times area (A) } \\ \text { ZEH } & \text { zero energy home } \\ & \end{array}$




\section{Acknowledgments}

We express our gratitude to George James and Ed Pollock, U.S. Department of Energy, for the leadership and resources needed to complete this work. Many thanks to Alden Hathaway and the whole Hathaway family for inviting us into their home for testing and monitoring. Many thanks also to Tim Merrigan and Craig Christensen of the NREL Zero Energy Homes team for their comments and insights. We are indebted to Ren Anderson, Mark Eastment, and Ron Judkoff of NREL for their thoughtful reviews and comments and Nancy Wells of NREL for her technical editing and document preparation work support.

We would like to acknowledge the help of two James Madison University students - Ashley Abbott and Kenneth Armstrong for their valuable assistance in instrumenting the Hathaway house. 


\section{Abstract}

This report details the monitored and modeled performance of a solar home outside of Washington, D.C. We modeled the home energy performance using DOE2.2, performed numerous short-terms tests on the home, and monitored its occupied performance for 29 months. The home used modular construction, solar water heating, a ground-coupled heat pump, efficient appliances, and compact fluorescent lighting to reduce its energy consumption by $35 \%$ compared to the Building America research benchmark home. The addition of $6 \mathrm{~kW}$ of photovoltaics (PV) increased the savings to $67 \%$ compared to the Building America research benchmark. A more efficient shell to reduce space conditioning loads would have brought the home closer to its zero energy goals. However, even with efficient lighting and appliances, the lights, appliance and plug loads were a significant energy consumer. About $4 \mathrm{~kW}$ of PV was required to meet the needs of these loads alone. To achieve the zero energy goal with no further efficiency increases, the Hathaway house would need about $2.6 \mathrm{~kW}$ of PV in addition to the $6.0 \mathrm{~kW}$ it now has. Applying advanced efficiency measures available or being developed, such as heat-recovery ventilation, superinsulation, and electrochromic windows, could reduce the heating, cooling, and domestic hot water (DHW) energy use to less than $1700 \mathrm{kWh}$ per year, an $88 \%$ reduction in these loads from the Building America Benchmark. At this efficiency level, the appliance and plug loads come to dominate energy consumption and account for nearly $70 \%$ of the total energy use. This analysis points out that even with highly effective energy-savings technologies (pushed beyond levels currently practical), whole-house energy use reduction by efficiency measures is only about $60 \%$ without also reducing the energy use of appliances and plug loads largely considered outside the designer's jurisdiction.

\section{Introduction}

This report details the monitored and modeled performance of a solar home outside of Washington, D.C. The home uses modular construction, solar water heating, a ground-coupled heat pump, efficient appliances, and compact fluorescent lighting to reduce its energy consumption by $35 \%$ compared to the Building America research benchmark home ${ }^{1}$. The addition of $6 \mathrm{~kW}_{\mathrm{p}}$ of photovoltaics (PV) increased the savings to $67 \%$ compared to the Building America research benchmark.

\subsection{The Context}

How clean is clean enough? How efficient is efficient enough? These will be among the defining questions of the $21^{\text {st }}$ century. As the human population pushes past 6 billion on the way to 9 billion by $2050^{2}$ we are faced with increasing environmental consequences ... mass species extinction; toxic air, water, and land pollution; and global warming to name a few. Many of these consequences are related to our energy use and choices. It is clear that we will need to reduce our per capita environmental impact, at least in relation to our population growth if we wish to stabilize or reduce environmental degradation.

About a fifth of all energy consumed in the United States is consumed in the home. ${ }^{3}$ This represents a huge opportunity to reduce our energy consumption and make cleaner choices for the energy we do consume. The U.S. Department of Energy's Building America Program is 
working to increase the energy efficiency of new and existing homes while increasing comfort, durability, and resource efficiency. As part of this program, we pursue opportunities to research highly efficient homes with the goal of understanding what works, what doesn't work, and what are the most economic ways to reach very high efficiency targets.

\subsection{The "Solar Patriot" Home}

Imagine a home that produces as much energy as it consumes each year. That was the design goal of the "Solar Patriot" home constructed on the National Mall in Washington, D.C., as part of the American Solar Energy Society (ASES) annual conference in the spring of 2001 (Figure 1). ${ }^{4,5,6,7}$ The home was designed by owner Alden Hathaway of the Environmental Resources Trust and builder Don Bradley of Solar Strategies Development Corporation. Construction of the home on the National Mall was accomplished in part with support from the Department of Energy (DOE) $)^{8}$ through the National Renewable Energy Laboratory's (NREL) ${ }^{9}$ Zero Energy Homes (ZEH) Program. ${ }^{10}$ After exposing more than 30,000 people to the potential of marketable, highly efficient, solar homes while it was on display on the National Mall, the home was moved to its permanent location outside of Washington, D.C., in Purcellville, Virginia. The Hathaway family moved into the home in August 2001. The following month staff from NREL visited the home and, with support from the DOE's Building America Program, ${ }^{11}$ installed a data-collection system to measure the performance of the home. In addition to the measured performance, a detailed computer simulation of the house was created using DOE2.1 home energy simulation software. This simulation was also used in conjunction with a newly developed NREL research tool called Building Energy Optimization (BEopt) that uses DOE2.1 and the TRaNsient SYstem Simulation (TRNSYS) ${ }^{12}$ Program to explore optimum combinations of energy efficiency measures to reach energy savings goals. This report combines the information from all of these efforts to investigate the performance of the Hathaway house and use it as a case study for exploring highly efficient and zero energy homes.

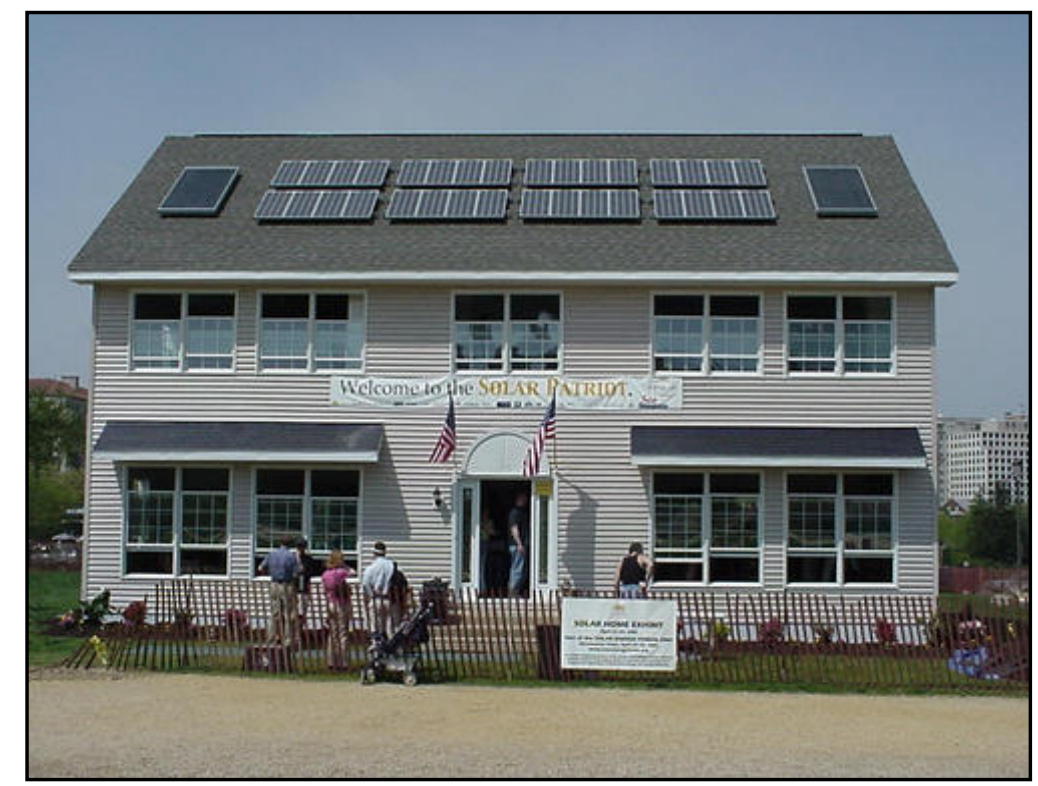

Figure 1. The "Solar Patriot" home on the National Mall in Washinaton. D.C. 


\subsection{The Hathaway House Specifications}

The home is modular construction consisting of four modules. After its debut on the National Mall, it was moved to its permanent location in a rural area of Purcellville, Virginia (Figure 2.) The home was placed on an insulated full basement constructed from Superior Wall ${ }^{\mathrm{TM}}$ precast concrete panels.

A building-integrated PV system was added to a standing-seam metal roof on the home and a detached garage was built to the east of the home. Collectors for an active solar water-heating system were placed on the roof of the garage along with a second PV array. The house was equipped with a ground-coupled heat pump system that supplies heating and cooling as well as backup water heating. A summary of the home specifications is given in Table 1. Floorplans are given in Figure 3.

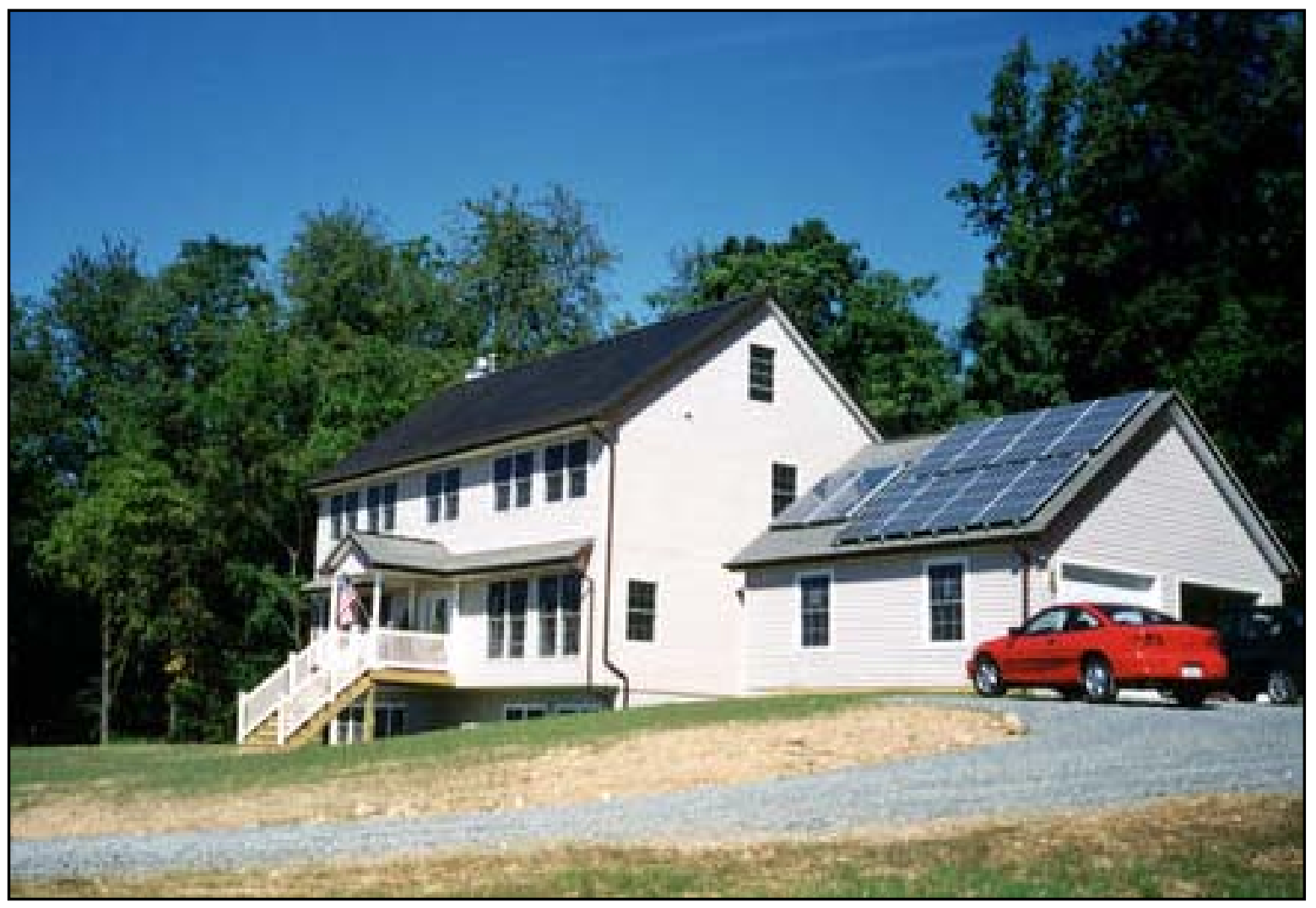

Figure 2. The Solar Patriot house at its permanent location in Purcellville, Virginia (Photo by Ed Hancock) 
Table 1. Summary of Specifications for the Hathaway House.

\begin{tabular}{|c|c|}
\hline Location & Purcellville, Virginia 22132 \\
\hline Builder & Don Bradley, Solar Strategies Development Corporation \\
\hline $\begin{array}{l}\text { Conditioned floor } \\
\text { area }\end{array}$ & $\begin{array}{l}2880 \mathrm{ft}^{2} \text { on two floors. Note that the basement and the third } \\
\text { floor are both insulated and equipped with supply registers, } \\
\text { but they were not being used as conditioned space during } \\
\text { the time of this study. }\end{array}$ \\
\hline Orientation & $\begin{array}{l}\text { Front of home faces } 10 \text { degrees west of magnetic south } \\
\text { (approximately true south) }\end{array}$ \\
\hline Wall construction & $\begin{array}{l}2 \times 6 \text { framing, } 24-i n ., \text { on center (OC), R-19 fiberglass batt } \\
\text { insulation with } \mathrm{R}-5 \text { insulating sheathing }\end{array}$ \\
\hline $\begin{array}{l}\text { Basement wall } \\
\text { construction }\end{array}$ & $\begin{array}{l}\text { Superior Wall }{ }^{\text {TM }} \text { precast concrete panels, } 8 \text {-ft ceiling } \\
1-1 / 2 \text {-in. of concrete, } 1 \text { in. of rigid polystyrene foam (R- } 5 \text { ), } \\
\text { R-19 fiberglass batts between } 2.25 \text {-in. } \times 7 \text {-in. concrete ribs }\end{array}$ \\
\hline Window type & $\begin{array}{l}\text { Seven-D Industries, Inc., Series } 9000 \text {, double-glazed, } \\
U=0.35, S H G C=0.37 \text { (south-facing windows have } \\
\text { approximately } 24 \text {-in. overhangs) }\end{array}$ \\
\hline $\begin{array}{l}\text { Space-conditioning } \\
\text { system }\end{array}$ & $\begin{array}{l}\text { Direct Axxess }{ }^{\circledR} \text { ground-coupled heat pump with horizontal } \\
\text { ground heat-transfer piping buried } 10 \mathrm{ft} \text { under the front } \\
\text { (south) yard of the home. Home is also equipped with a } \\
\text { wood-burning fireplace. }\end{array}$ \\
\hline $\begin{array}{l}\text { Water-heating } \\
\text { system }\end{array}$ & $\begin{array}{l}\text { Two Duke Solar CPC- } 2000 \text { compound parabolic } \\
\text { concentrator collectors }\left(4.5-\mathrm{m}^{2} \text { total collector area) }\right. \\
\text { connected to a single } 80 \text {-gallon storage tank. Backup water } \\
\text { heating is accomplished with the ground-coupled heat } \\
\text { pump. }\end{array}$ \\
\hline Appliances & $\begin{array}{l}\text { Refrigerator, clothes washer, and dishwasher are ENERGY } \\
\text { STAR®-rated. Clothes dryer and oven are electric. Stove is } \\
\text { propane. }\end{array}$ \\
\hline Lighting & Compact florescent lighting is used throughout the home \\
\hline PV Systems & $\begin{array}{l}\text { Grid connected with battery back-up (no maximum power } \\
\text { point tracker) } \\
\text { Home array: Nominal } 4 \mathrm{~kW} \text { Unisolar amorphous } \\
\text { Garage array: Nominal } 2 \mathrm{~kW} \text { BP Solar monocrystalline } \\
\text { Inverters: Two Xantrex Model SW Series II inverters }\end{array}$ \\
\hline
\end{tabular}



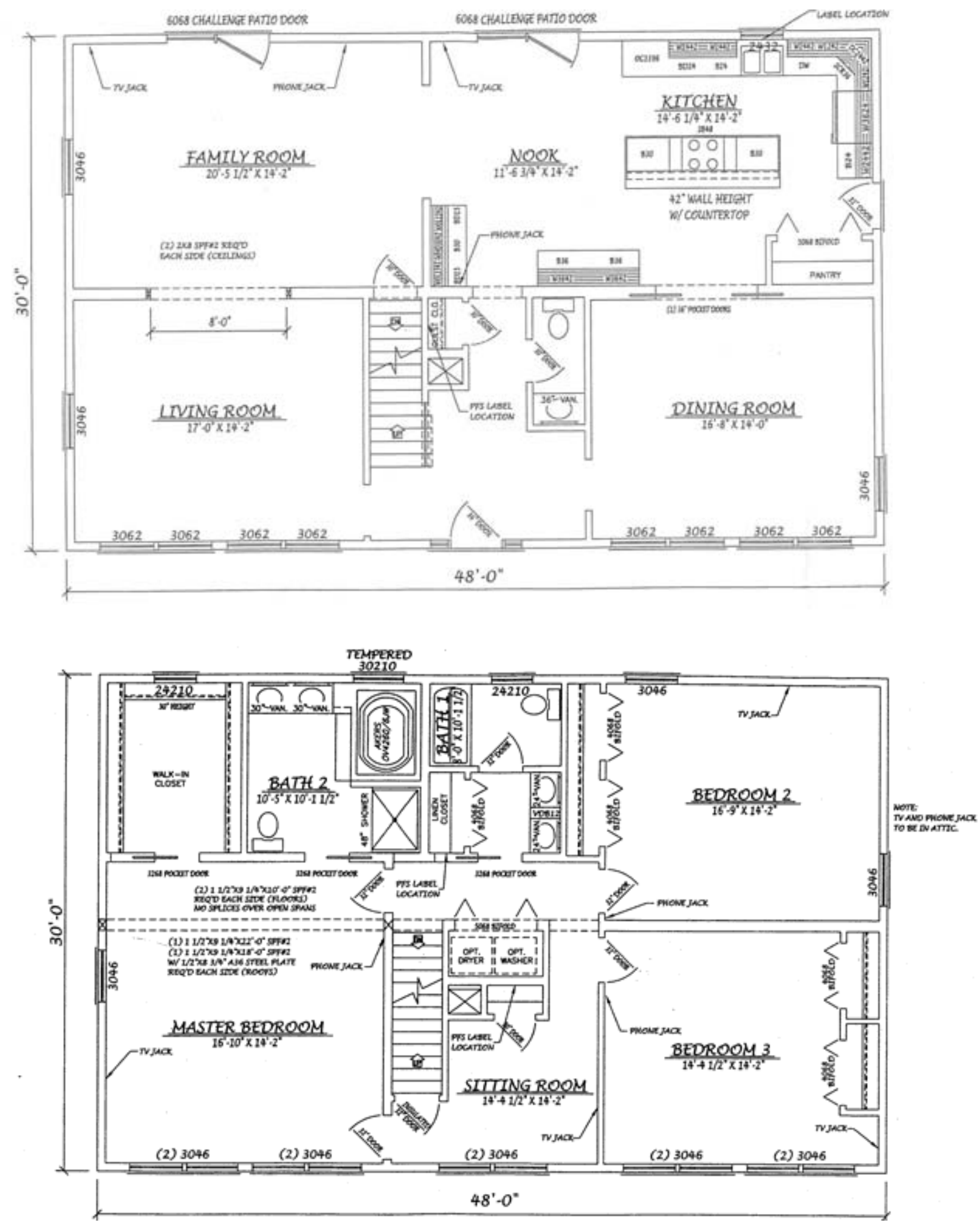

Figure 3. Floor plans for the first and second floors of the Hathaway House 
A utility room in the basement of the home contains the air handler, the heat pump, the water tank, breaker boxes, and PV inverters, charge controllers, and batteries. The ducts for the basement and first floor run in the floor between the basement and the first floor. A central supply trunk runs vertically through the home in the chase beside the stairs (see Figure 3 for the location of the chase). This supply trunk runs all the way to above the space in the attic that will eventually be finished and then runs the length of the house in this space (Figures 4 and 5) to the peak where supply ducts descend back along the roof sheathing to supply air to the second floor and attic. As shown in Figures 4 and 5, the floor of the attic is insulated with fiberglass batts. In the winter of 2003 the walls and ceiling of the framed-in attic space that will eventually be finished were insulated with sprayed-in cellulose (Figure 6). As of publication, the attic space was completed and was not being heated. Likewise the basement is insulated, but is not being actively conditioned.

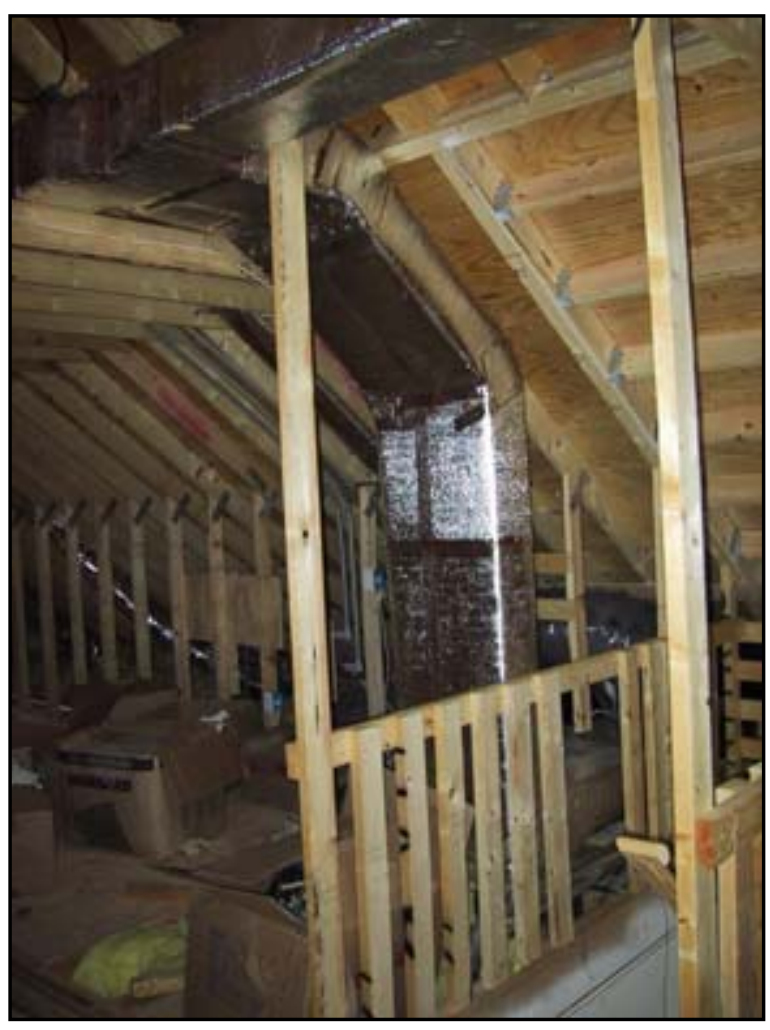

Figure 4. Duck supply trunk entering attic and continuing to trunk above the framing for the finished space
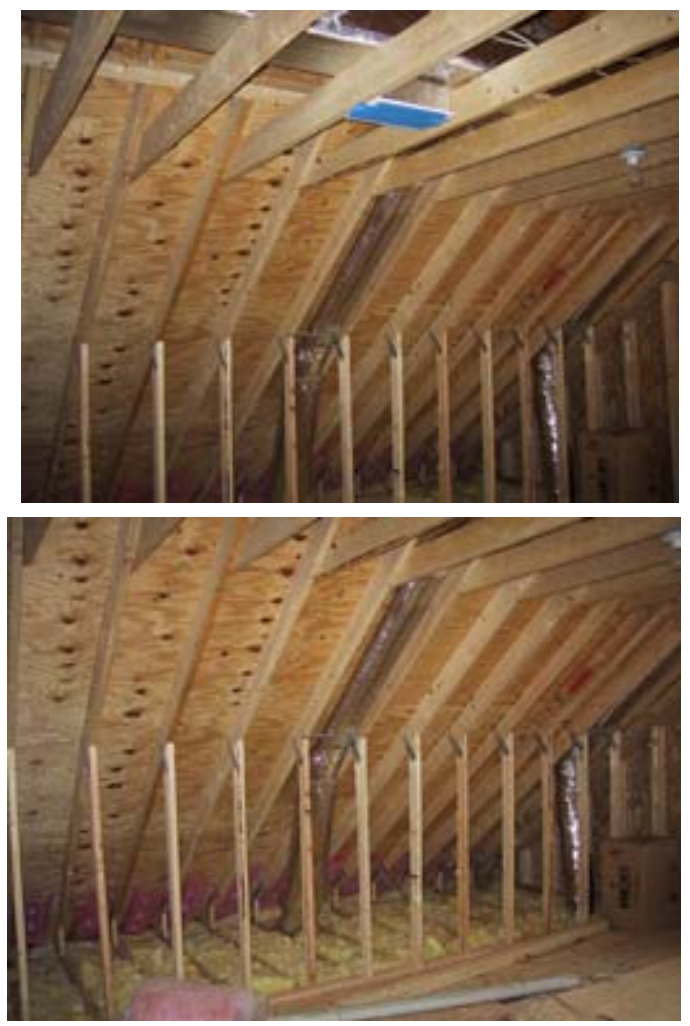

Figure 5. Supply register for attic space (top photo) and supply duct descending to ceiling register for second floor (bottom photo) 


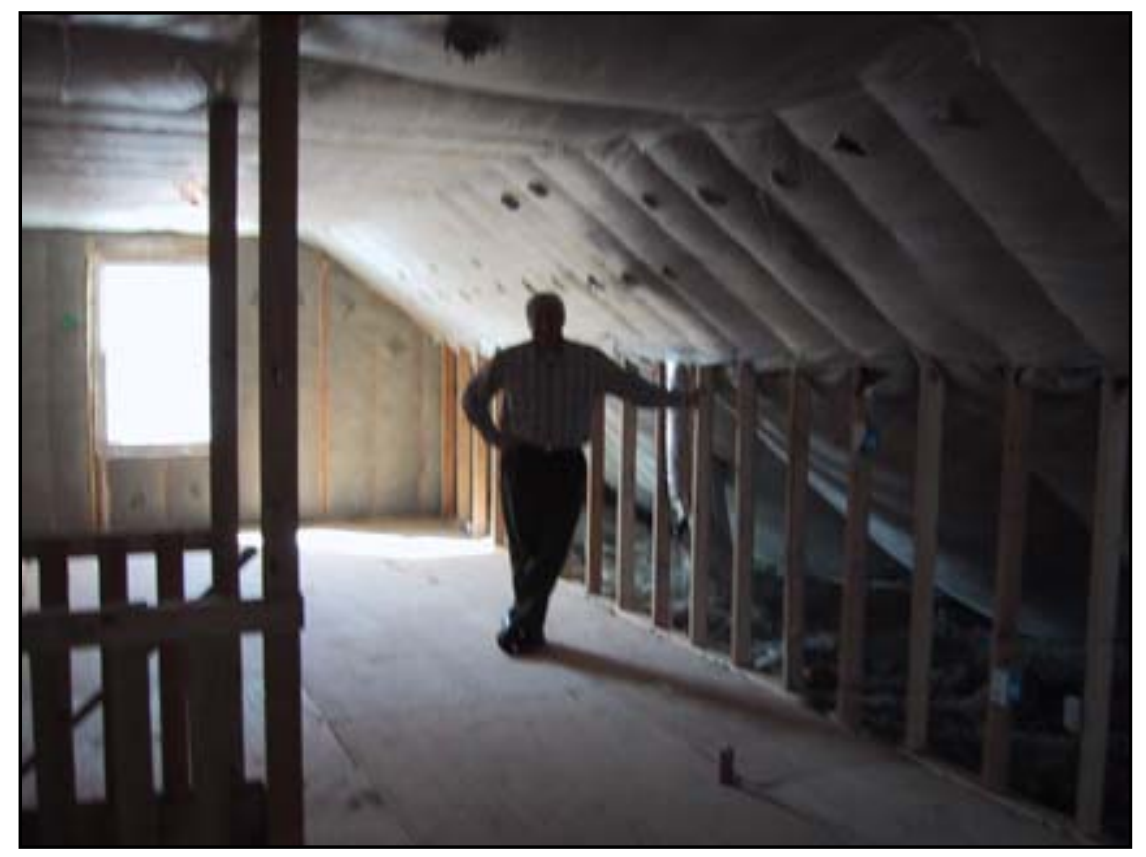

Figure 6. Alden Hathaway and blown-in cellulose insulation in attic

The 6-kW PV system is grid connected with a battery back-up that supplies power to the house during blackouts The controller does not include a maximum power-point tracker.

The house has a unique single-tank water-heating system using the ground-coupled heat pump to back-up the solar water heater. During the day, the solar system exclusively warms the water in the 80-gallon storage tank. A timer controls the back-up heating from the heat pump. In the early morning hours, just before the Hathaways awake, the heat pump is used to raise the temperature of the water, preheated by the previous day's solar gain, to the setpoint temperature. The heatpump water heating is then shut off. The Hathaway's morning water use leaves the water in the tank at a temperature cool enough to take advantage of the solar heat gain for the remainder of the day.

\subsection{Study Objectives and Overview}

This study was funded by the Department of Energy's Building America program (www.BuildingAmerica.gov). The Building America program is engaged in research with builders throughout the country to reduce energy consumption in new homes by an average of $30 \%$ to $90 \%$ while increasing comfort and durability and decreasing material waste. In the past 8 years, 26,000 energy-savings homes have been built as part of the program. The program is now focusing its substantial technical expertise and experience on cost effectively achieving higher energy-savings ratios. The Hathaway Solar Patriot house is an example of a home that was designed to achieve a high level of energy savings through energy-efficient features and to meet the remaining electrical energy needs through the use of solar energy (PV). The home provides an excellent case study for the Building America program. Building America's long-term 
research goal is to develop cost-effective, production-ready homes that achieve zero net energy by the year 2020. A net zero energy home produces as much energy as it consumes on an annual basis.

The objective of the research outlined in this report is to answer the following questions:

1. Does the home meet its design objective of reaching zero energy? Is so, how? If not, why not?

2. How do the features of the home contribute to its overall energy efficiency?

3. How much energy does the home consume compared to the Building America benchmark?

4. What would be the most cost effective ways to improve the energy efficiency of the design?

We used a combination of short-term tests, long-term monitoring, and computer simulation to answer these questions.

\section{Short-Term Testing}

Throughout the study, short-term tests were used to measure characteristics of the home that are not easy to determine from plans or specifications. Some of the results of these tests were later used to improve the accuracy of the computer simulations of the home and the confidence in the results from those simulations. Short-term tests also provide a quality check on some aspects of the home (such as air tightness and duct leakage) and assure that energy features (the PV system for example) are operating properly. The short-term tests performed on the Hathaway house are listed below then discussed in detail.

\section{Air-exchange Characteristics}

- Shell leakage measurement (blower door and tracer gas)

- Duct leakage measurement (duct blaster and tracer gas)

- Register flow measurement (flow hood)

- Air handler flow measurement (flow plate)

\section{Heat-Pump Coefficient of Performance (COP)}

Other Short-term Measurements and Observations

- IR photography

- Fireplace operation

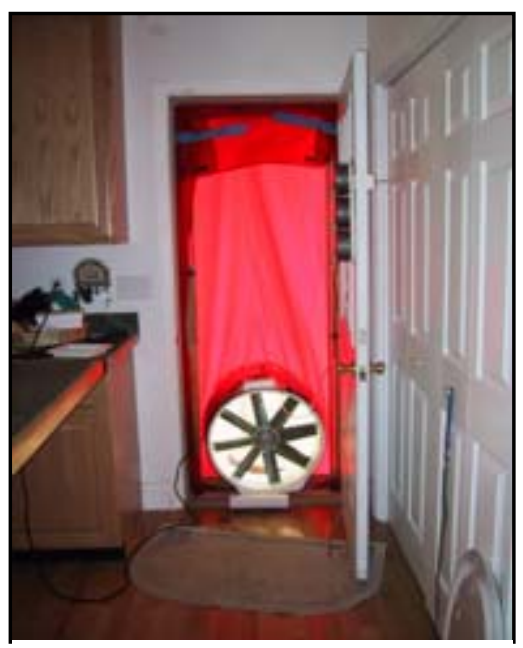

Figure 7. Blower door installed in the Hathaway House 


\subsection{Air Exchange Characteristics}

On September 18, 2001, Glenn Chinery of the EPA's ENERGY STAR $®$ Homes Program and Don Mauritz of Lawrence Berkeley National Laboratory (LBNL) joined NREL staff at the Hathaway house. Glenn and Don brought a blower door to test the air tightness of the home and ducts. While they were there, we also used the blower door in conjunction with a duct blaster to measure the duct leakage. The blower door was placed in the kitchen door as shown in Figure 7.

The conditions for the tests were as follows:

- Attic door was closed and sealed (because the attic was unfinished at that time)

- Attic registers were taped closed

- Basement door was open and included in the measurement

- Fireplace flue was closed

- Unused PVC conduits in the basement were taped closed

- Outside air was relatively still with occasional mild breezes.

TECTITE blower-door software from The Energy Conservatory was used to determine the equivalent leakage area (ELA) of the home. The results of the blower door and duct blaster tests are given in the Table 2 . 
Table 2. Results of Blower Door and Duct Testing

\begin{tabular}{|c|c|c|c|}
\hline & $\begin{array}{l}\text { With duct } \\
\text { registers } \\
\text { taped } \\
\text { CLOSED }\end{array}$ & $\begin{array}{l}\text { With duct } \\
\text { registers } \\
\text { OPEN }\end{array}$ & Difference \\
\hline \multicolumn{4}{|l|}{ Blower Door Results } \\
\hline $\mathrm{CFM}$ at $50 \mathrm{~Pa}$ & 2241 & 2326 & 85 \\
\hline $\mathrm{ACH}^{*}$ at $50 \mathrm{~Pa}$ & 3.73 & 3.88 & 0.15 \\
\hline ELA (in. ${ }^{2}$ at $4 \mathrm{~Pa}$ ) & 132.5 & 146.8 & 14.3 \\
\hline Correlation Coefficient $\left(r^{2}\right)$ & 0.99935 & 0.99639 & \\
\hline Flow Coefficient (C) & 197.7 & 227.0 & \\
\hline Exponent (n) & 0.621 & 0.595 & \\
\hline \multicolumn{4}{|l|}{ Average Annual Infiltration ${ }^{* *}$} \\
\hline Average annual ACH & 0.17 to 0.19 & 0.18 to 0.20 & \\
\hline Climate Factor (C) & 20 to 23 & 20 to 23 & \\
\hline Height Factor (H) & 0.8 & 0.8 & \\
\hline Wind Shielding Correction Factor (S) & 1.2 & 1.2 & \\
\hline Leakiness Correction Factor (L) & 1.0 & 1.0 & \\
\hline \multicolumn{4}{|l|}{ Duct Blaster Results @ 25 Pa } \\
\hline Total (cfm) & 555 & & \\
\hline Total to outside*** $(\mathrm{cfm})$ & 219 & & \\
\hline
\end{tabular}

* air changes per hour

** Estimated using the LBNL infiltration model and the assumed factors shown

*** Measured with house pressurized to $25 \mathrm{~Pa}$ with the blower door 
In the past, some modular homes have not achieved good air tightness because of leakage where the modules came together (the "marriage walls"). With less than four air exchanges per hour $(\mathrm{ACH})$ at 50 Pascal depressurization, the Hathaway house had good air tightness. The projected average annual ACH is about 0.2. The addition of mechanical ventilation to the home should be considered. The ASHRAE standard 62.2, Ventilation and Acceptable Indoor Air Quality in LowRise Residential Buildings, ${ }^{13}$ would recommend mechanical ventilation for this home.

We measured the air flow rates at the registers throughout the house using an Alnor Low-Flow Balometer with a range of 10 to $500 \mathrm{cfm}$ and a rated accuracy of $\pm 3 \%$ of reading $+2 \mathrm{cfm}$. The flow rate of the supply registers on the first floor was measured with no filter, a dirty filter, and a clean filter in the air handler. The results of these measurements are given in Table 3. 
Table 3. Register and Exhaust Fan Flow Results

\begin{tabular}{|c|c|c|c|}
\hline \multirow[b]{2}{*}{ Room (Register) } & \multicolumn{3}{|c|}{ Measured Air Flow Rates (cfm) } \\
\hline & Without filter & With dirty filter & With clean filter \\
\hline \multicolumn{4}{|l|}{ Supply Registers } \\
\hline Dining room (1) & 94 & 76 & 86 \\
\hline Dining room (2) & 87 & 67 & 88 \\
\hline Entry & 46 & 37 & 46 \\
\hline Living room (1) & 89 & 66 & 83 \\
\hline Living room (2) & 92 & 76 & 90 \\
\hline Family room (1) & 80 & 60 & 70 \\
\hline Family room (1) & 28 & 21 & 22 \\
\hline Breakfast room ("Nook") & 58 & 48 & 54 \\
\hline Kitchen (1) & 30 & 20 & 25 \\
\hline Kitchen (2) & 70 & 51 & 63 \\
\hline First floor total & 674 & 522 & 627 \\
\hline Master Bedroom (1) & 71 & & \\
\hline Master Bedroom (2) & 79 & & \\
\hline Master closet & 38 & & \\
\hline Master bathroom & 48 & & \\
\hline Hall bathroom & 46 & & \\
\hline NE bedroom & 76 & & \\
\hline SE bedroom (1) & 73 & & \\
\hline SE bedroom (2) & 73 & & \\
\hline Office ("Sitting room") & 71 & & \\
\hline Second floor total & 575 & & \\
\hline Basement (1) & 80 & & \\
\hline Basement (2) & 80 & & \\
\hline Attic (1) - closed & 0 & & \\
\hline Attic (2) - closed & 0 & & \\
\hline Total for all supply registers & 1409 & & \\
\hline \multicolumn{4}{|l|}{ Return Registers } \\
\hline $1^{\text {st }}$ floor entry & $>500$ & & \\
\hline $2^{\text {nd }}$ floor entry & $>500$ & & \\
\hline Office ("Sitting room") & 238 & & \\
\hline Master Bedroom & 65 & & \\
\hline \multicolumn{4}{|l|}{ Exhaust Fans } \\
\hline $1^{\text {st }}$ floor bathroom & 13 & & \\
\hline $2^{\text {nd }}$ floor hall bathroom & 46 & & \\
\hline Master bathroom & 33 & & \\
\hline
\end{tabular}


Table 4. Flow-Plate Measurements of the Total Air Flow Rate at the Air Handler

\begin{tabular}{|l|c|c|}
\hline Filter Condition & $\begin{array}{c}\text { Return Reference } \\
\text { Pressure (Pa) }\end{array}$ & $\begin{array}{c}\text { Air-flow Rate } \\
\text { (cfm) }\end{array}$ \\
\hline Dirty filter & 34 & 1434 \\
\hline No filter & 53 & 1795 \\
\hline Best filter & 41 & 1580 \\
\hline New filter & 47 & 1672 \\
\hline
\end{tabular}

We measured the total air-flow rate at the air handler fan using a Energy Conservatory True Flow flow plate in the air filter slot. We measured the flow rates for different air filters and with different levels of filter dirt accumulation (Table 4).

The "dirty" filter condition was for the filter condition as found at the start of the testing. It was an inexpensive (\$1.50) glass-fiber filter that had not been changed for an extended time. The "best" filter was an expensive (\$15) pleated-fabric filter that was intended to have significantly improved filtration, but also had a higher pressure drop. The "new" filter was a direct replacement for the inexpensive original filter. The measurements indicated that the dirty filter reduced the system flow rate by about $240 \mathrm{CFM}$ or about $15 \%$ compared to the new filter. We recommended that Mr. Hathaway replace this filter about once every 3 weeks of normal operation.

The Alnor flow-hood measurements indicated a similar reduction in air flow rate as the filters were changed. The total of the supply flows measured at each register with the flow hood was about $20 \%$ less the total flow measured with the flow plate.

The total duct leakage for the home was quite high at 555 cubic feet per minute at $25 \mathrm{~Pa}$ pressurization. This was approximately $35 \%$ of the total air-handler flow. A tight duct system will leak at a rate of less than $10 \%$ of the total air-handler flow rate. Separate supply and return leakages were not measured. We measured the duct leakage to the outside by pressurizing the home to the same pressure as the ducts $(25 \mathrm{~Pa})$ and measuring the leakage from the ducts. The leakage to the outside was $219 \mathrm{cfm}$, approximately $14 \%$ of the total air-handler flow rate.

Because the basement was included as indoor space in the blower door and duct blaster tests, the leakage to the outdoor was likely occurring in the attic. The effect of duct leakage will be discussed further in the Section 5: Simulated Energy Performance.

A Bruel and Kjaer multi-point tracer gas-monitoring system was installed in the Hathaway home to measure air exchange rates from March 2-4, 2002. Sulfur hexafluoride (SF6) was periodically injected and mixed to a nearly uniform concentration. The decay in concentration of SF6 indicated the rate of air exchange with the outside expressed as ACH. Two sampling points were located on the first floor, two on the second floor, and one in the basement. The average of the 
$\mathrm{ACH}$ in the four zones from the first and second floor is plotted in the time-series graph in Figure 8. Included in this graph is the calculated ACH using the LBNL model as described in the ASHRAE Handbook of Fundamentals 1997. The inputs to this model include the ELA from the blower door test, measured wind speed, outside temperature, and inside temperature during the tracer gas test. The LBNL model generally predicts the lower range of the measured air exchange rates. The measured higher air exchange rates on Saturday midday, Saturday evening, and Sunday midday were correlated with use of the fireplace and with family activity. This may imply that fireplace use causes increased air infiltration, or that increased infiltration may be caused by doors opened during family activity, or that the LBNL model is not accurate at this level of detail.

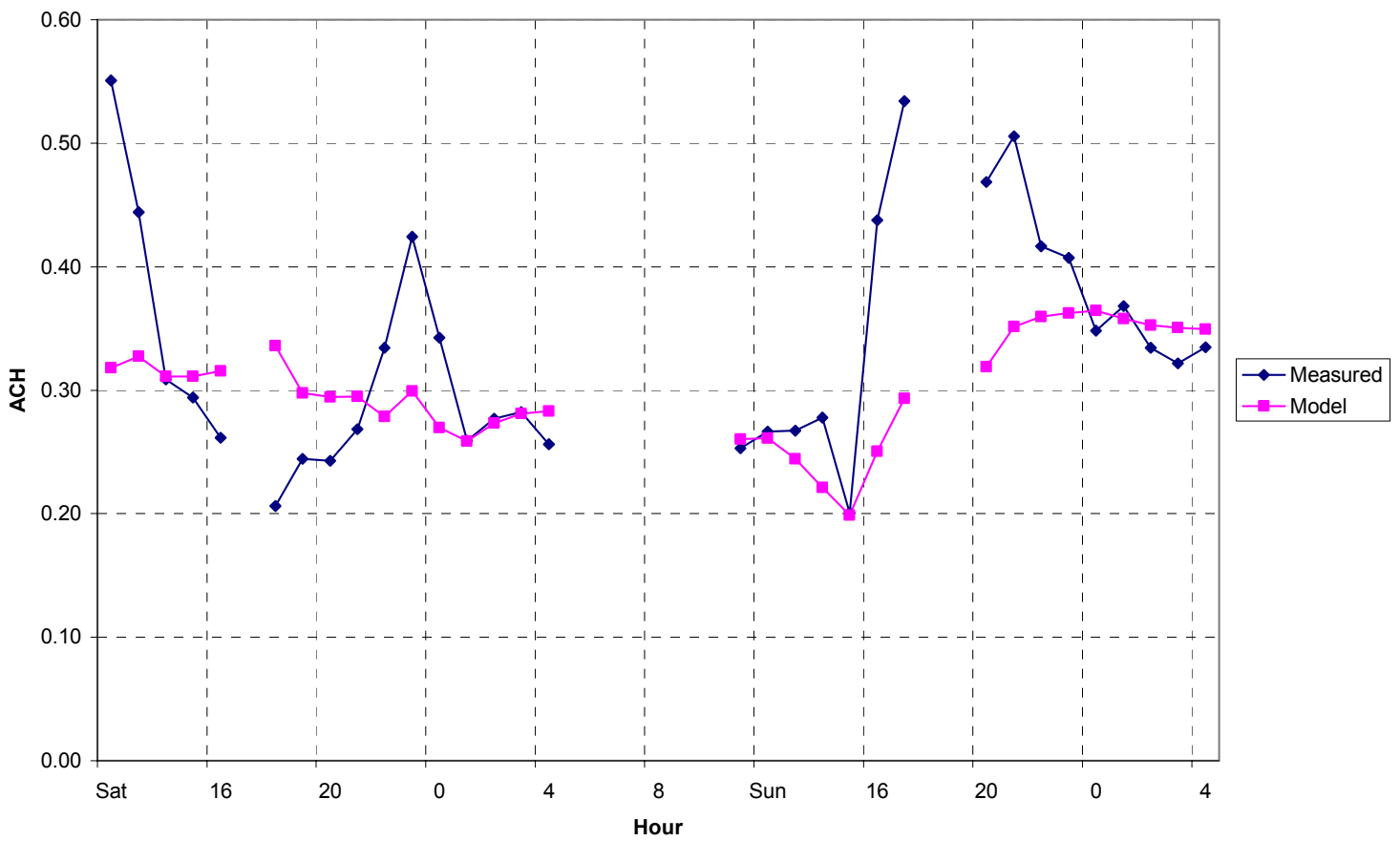

Figure 8. Comparison of tracer gas $\mathrm{ACH}$ measurements to $\mathrm{ACH}$ modeled using blower door ELA measurement 


\subsection{Heat-Pump Coefficient of Performance (COP)}

A ground-coupled heat pump was chosen to efficiently meet the home's space heating, space cooling, and back-up water-heating needs. We were interested in performing a check of this systems coefficient of performance (COP). To estimate the COP during space-heating operation, we measured air flow and temperatures before and after the coil in the air handler. For selected hours of operation we used the flows and the changes in temperature to estimate delivered energy and compared this to the energy consumption of the heat pump. Because we measured only the sensible load, we estimated the latent load resulting from the moisture removed from the air during cooling to derive the COP in the cooling mode. The COP for water heating was calculated from tank temperature increase, measured tank losses, and heat-pump energy consumption.

\subsubsection{Heating Mode COP}

To measure the air-supply temperatures, we installed thermocouples in the supply air ducts in the basement mechanical room. The supply ducts branch into three parts immediately downstream from the air handler. The two branches supplying the first floor and basement had a location available to install the thermocouples at least 10 feet downstream from the air handler to allow for adequate mixing of the air. In these two branches, one thermocouple was installed in each branch. We used a hot wire anemometer to check for uniform air-temperature distribution at these locations before installing the thermocouples. In the branch that supplies the second floor and attic, the only easily accessible location for thermocouple installation was about 1.5 feet downstream from the air handler. Three thermocouples were installed across the section of the duct to account for any non-uniformity of air temperature. These three thermocouples were measured in parallel at the data logger to indicate an average temperature. Readings from these thermocouples while the heat pump was in heating mode indicated that all of the supply temperatures were within about $1^{\circ} \mathrm{F}$ of each other, implying a relatively uniform temperature leaving the heating coil. The return air temperature was assumed to be equal to the average of the indoor temperatures measured on the first and second floors. We used the results of the airhandler flow rate test described in section above for the airflow in the COP estimates. Mr. Hathaway changed his air filter frequently, so the clean filter airflow rate was used for the COP estimates. Monitored data for hours when the heating system was on nearly continuously and when the system did not deliver heat to the hot-water system were used to calculate the COP of the heat pump in heating mode. The results for the 65 hours during the monitored period that met the criteria stated above are shown in Figure 9. The average heating COP is 3.6, not including the supply fan power. If the supply fan power is included in the COP definition, the average heating COP is 2.9 .

We expected heat pump COP to be a function of ground temperature in the geothermal field and air temperature inside the house. The presence of the heat-extraction tubes may also affect the local ground temperature. As shown in Figure 9, the average calculated heating COP values in November and December were somewhat higher than the values determined for March. Whether this is a seasonal trend or a longer-term trend influenced by the introduction of the ground-source heat pump has not been determined 


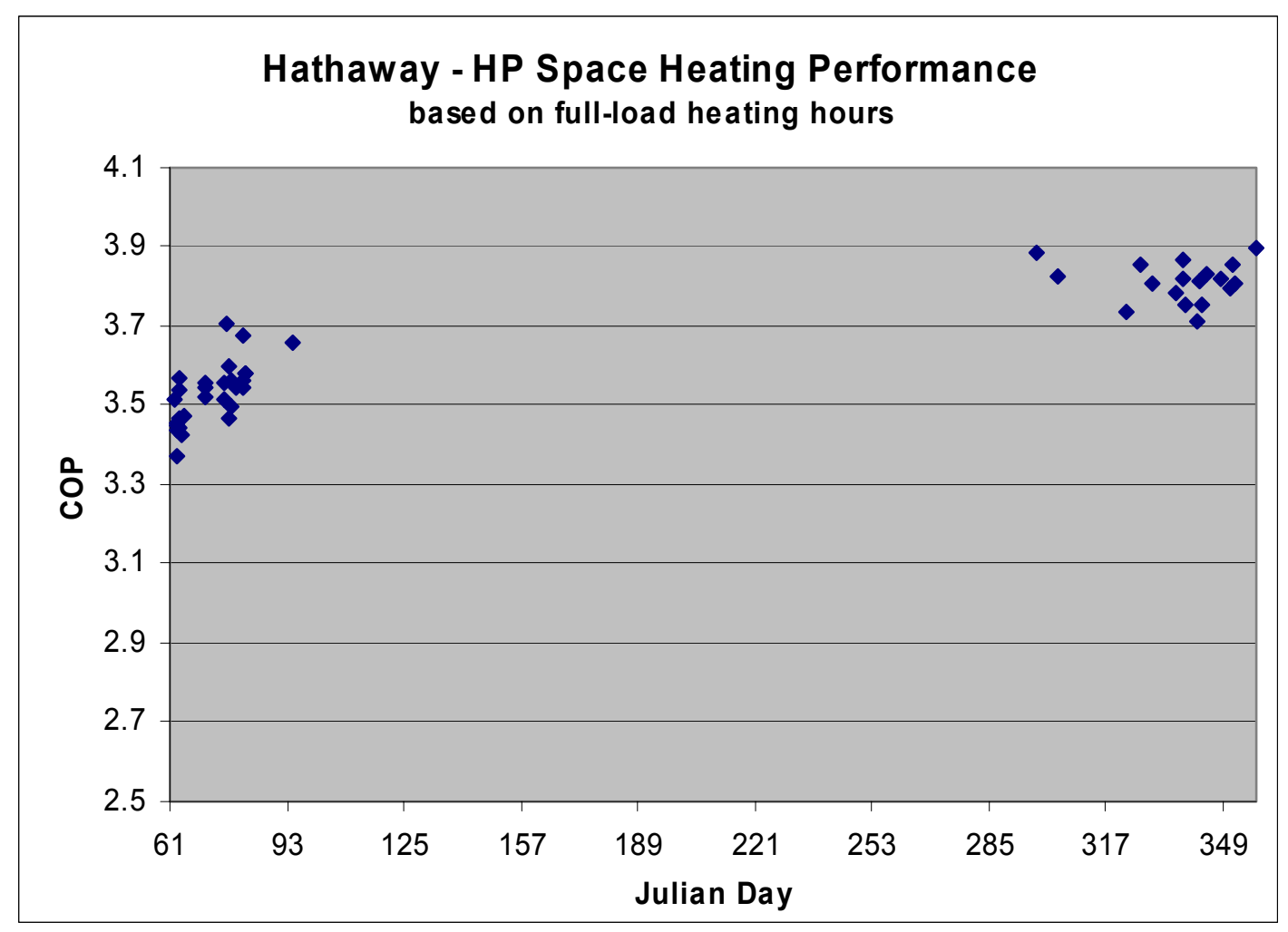

Figure 9. Space-heating COP determined from monitored data (fan power not included)

\subsubsection{Cooling Mode COP}

A direct calculation of the cooling COP of the heat pump system could not be made because the latent load of the cooling coil was not monitored. The COP of the sensible load only can be determined in a manner similar to the heating performance analysis above. The result of this analysis is shown in Figure 10. In this case, the average sensible cooling COP was 2.6 without and 2.1 with the fan power included. Assuming a sensible heat ratio of 0.8 , the total cooling COP without and with fan power included is 3.2 and 2.6, respectively. The average outdoor temperature coincident with the cooling performance calculations was $85^{\circ} \mathrm{F}$. To model the system performance in cooling mode, an estimate of the latent load resulting from moisture removal was added to the sensible heat COP calculation. 


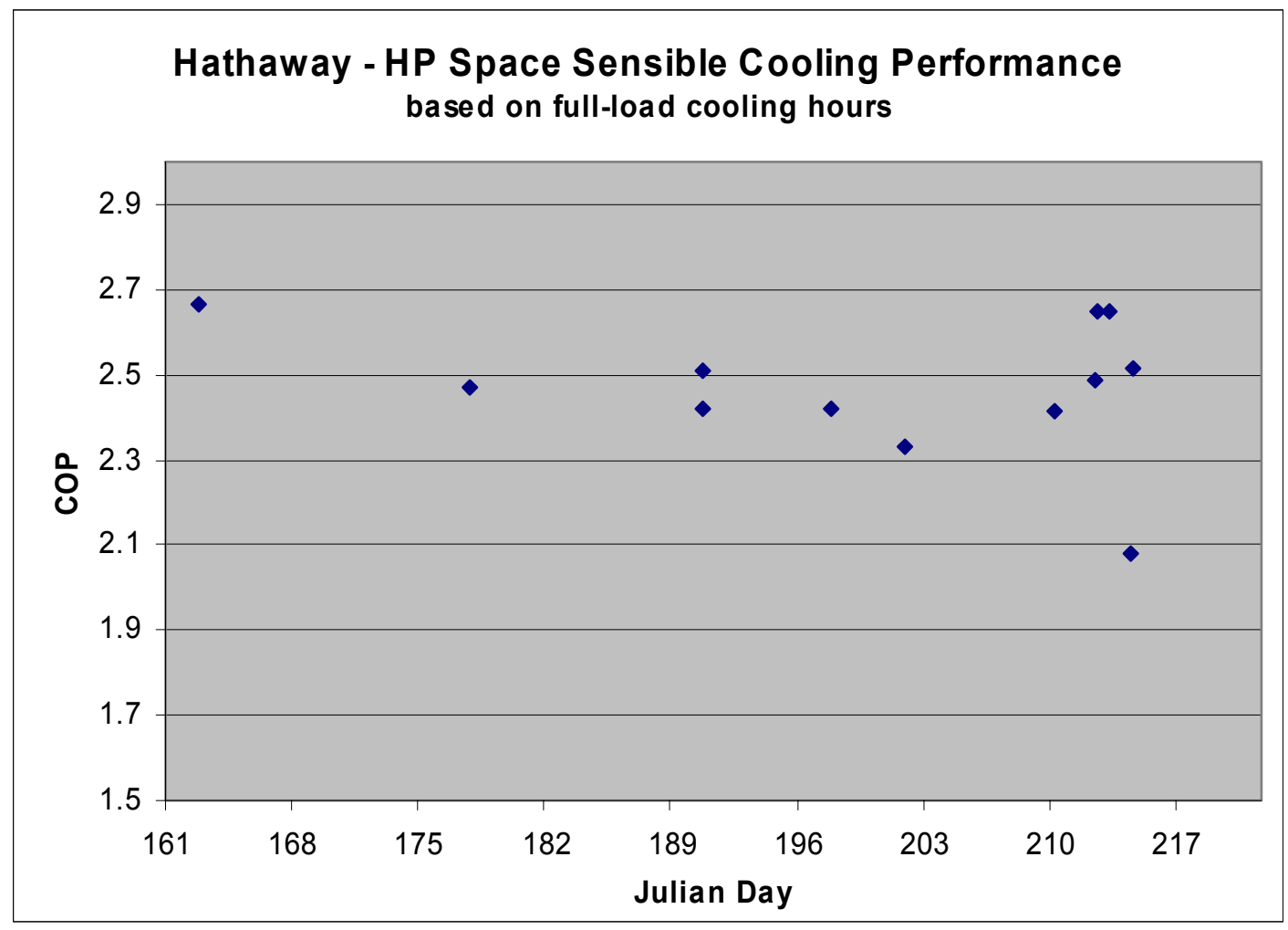

Figure 10. Space-cooling COP determined from monitored data (fan power not included)

\subsubsection{Water-Heating COP}

The ground-source heat pump, along with an active solar hot-water system, provided heat to a 80 -gallon domestic hot-water tank. Extensive monitoring of the system allowed for the determination of the tank loss, hot-water load, the HP performance and, ultimately, the overall HP/Solar system performance.

We measured the water-storage tank temperature using a thermocouple attached to tank inside its insulation. We used the rate of change in hot-water storage tank temperature with respect to time $(\mathrm{C} / \mathrm{min})$, the nominal volume of water in the tank (80 gallons [303 kg]), and the heat capacity of water $(4.18 \mathrm{~kJ} / \mathrm{kg})$ to calculate the heat flow in watts. The COP was the ratio of the thermal output of the heat pump to the electric input. The COP was expected to change as a function of water temperature and ground temperature. The ground temperature changed seasonally and may appear relatively constant over the period of a month, but the water temperature changed (from cold to warm) during every cycle of the heat pump. The COP for water heating was initially calculated from 1-minute data to observe the change in COP as a function of water temperature. Figure 11 shows that the measured COP in water heating mode is about 2.0 at $20^{\circ} \mathrm{C}$ water and about 1.4 at $45^{\circ} \mathrm{C}$ water temperature. 


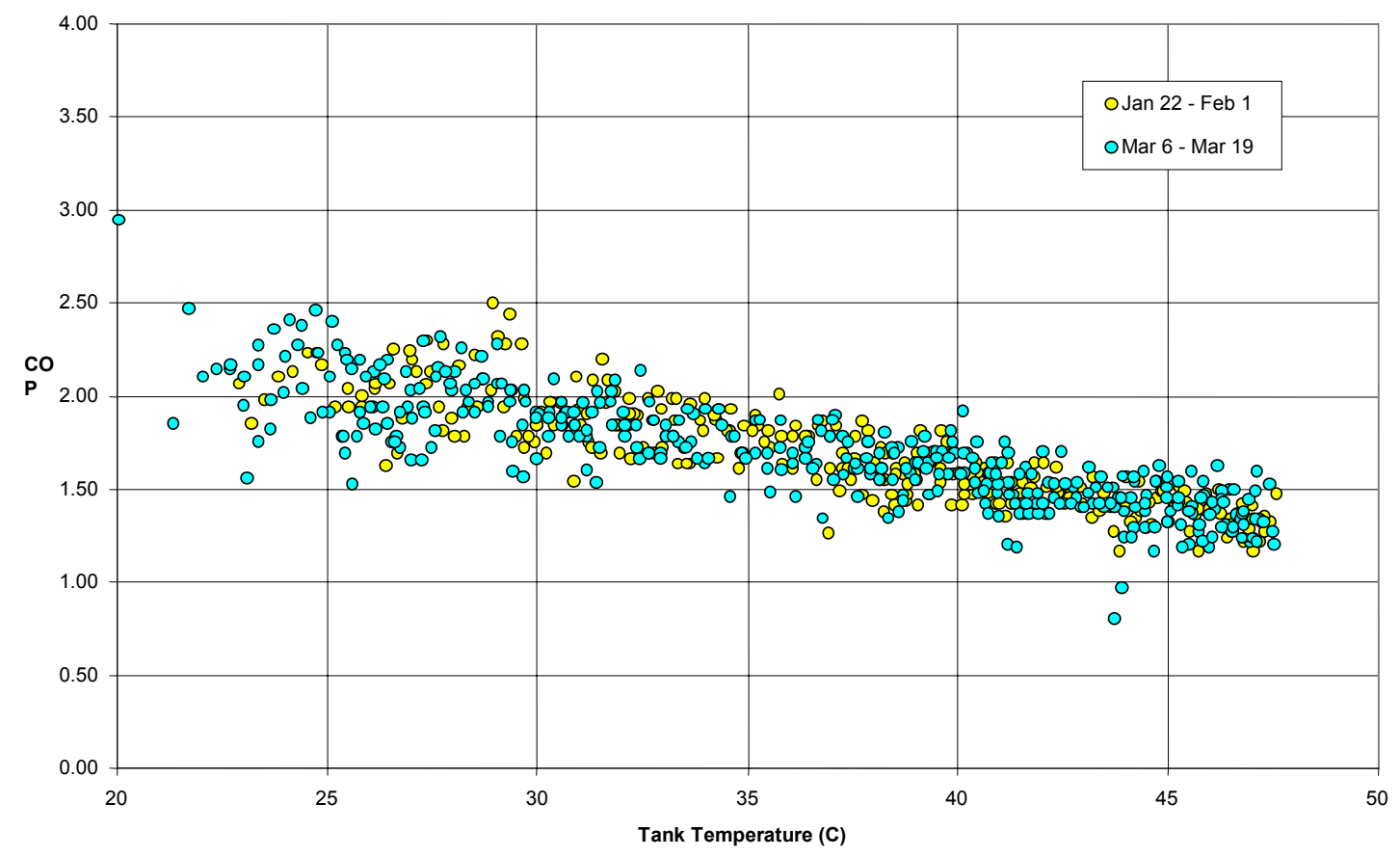

Figure 11. Coefficient of performance (COP) of heat pump for water heating

The tank UA (overall heat transfer coefficient [U] times area [A]) was determined by examining the hourly tank temperature and the basement temperature. During periods with no hot water usage and with no solar energy added to the tank, the tank UA could be estimated as the tank heat loss (as determined by the temperature drop of the tank) divided by the temperature difference between the tank and the basement. A plot of the calculated tank UA for every hour clearly showed a common value of 3.0 BTU/hr-F. This tank UA lead to an average tank loss of $132 \mathrm{BTU} / \mathrm{hr}$ during the monitored period.

The monitored data was examined to find periods when the heat pump charged the 80-gallon tank, without any significant hot water draw or solar heating contribution. The load of the hot water tank during these periods was defined only by the temperature rise of the water in the tank and the heat loss from the tank. The power use of the heat pump during these periods was used to determine the HP COP when charging the hot-water tank. 


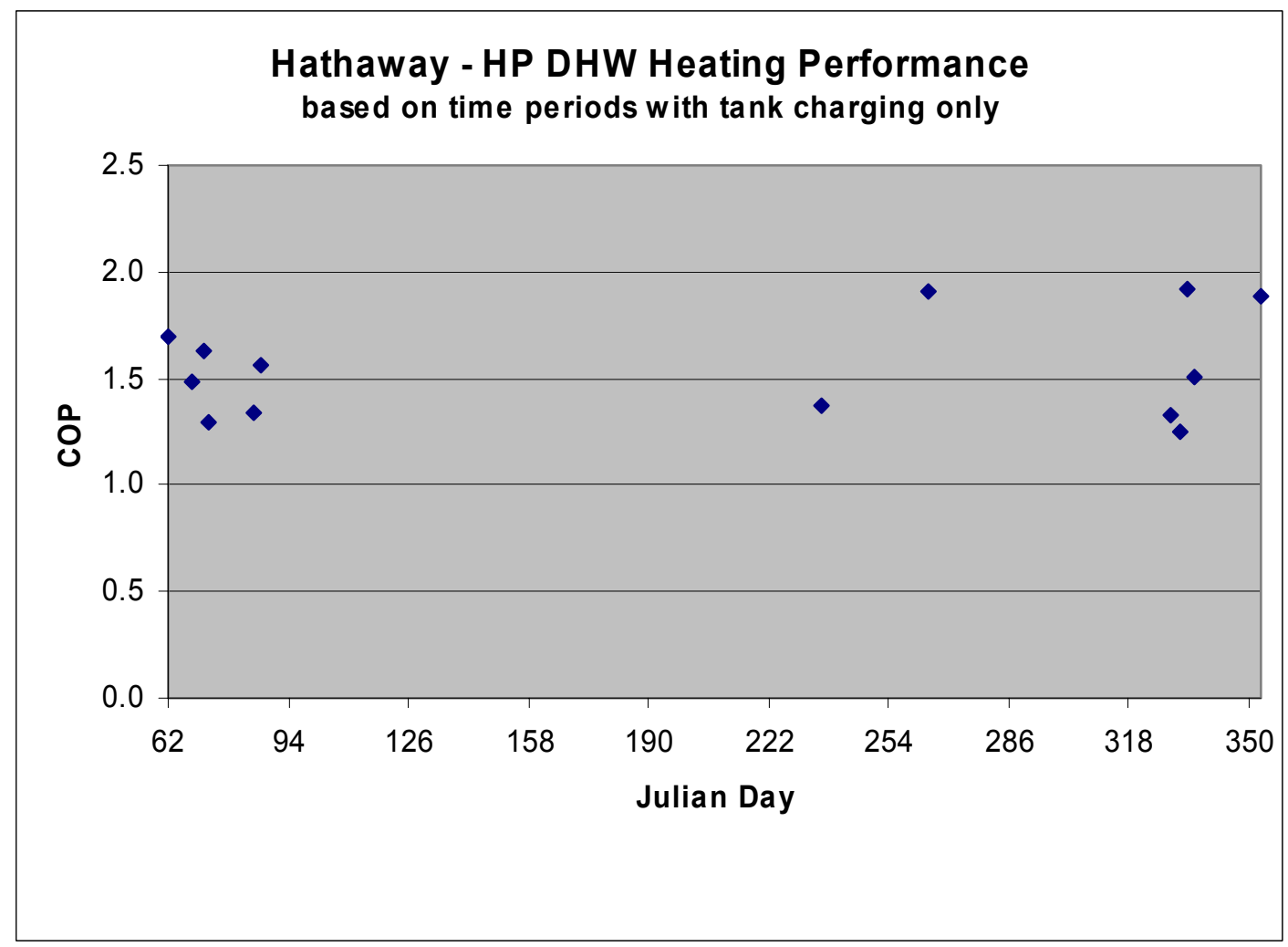

Figure 12. Domestic hot-water COP determined from monitored data

The average COP for the thirteen periods identified in Figure 12 was 1.55. This performance was consistent with the 1-minute measurements discussed above and was comparable to dedicated air-to-water heat-pump water heaters.

The actual hot-water energy demand was met by a combination of the solar collectors and the heat pump. As shown in Table 5, the total system COP of 3.5 included the heat-pump energy and solar-pumping energy used to deliver heat to the storage tank. This overall COP clearly varied as a function of weather conditions and use patterns. 
Table 5. Energy Balance for Domestic Hot Water system

\begin{tabular}{|l|rl|l|}
\hline Component & \multicolumn{2}{|c|}{ Value } & Source/Description \\
\hline Hot Water Load & & & \\
\hline load of hot water used & 8797329 & BTU & based on monitored flow and deltaT data \\
\hline $\begin{array}{l}\text { load resulting from heat loss from } \\
\text { tank }\end{array}$ & $1153305 \quad$ BTU & based on monitored temperature data \\
\hline total heating load & 9950634 & BTU & sum of above components \\
\hline HP energy used to heat water & $576 \quad \mathrm{kWh}$ & based on monitored power data \\
\hline HP energy delivered to water & 3051232 & BTU & based on an average HP dhw COP of 1.55 \\
\hline Solar energy delivered to water & 6899402 & BTU & total load minus HP energy delivered \\
\hline Solar Energy Fraction & $69 \%$ & & fraction of DHW heating load delivered by solar \\
\hline Solar pump energy used & 256 & $\mathrm{kWh}$ & from monitored data \\
\hline & & & \\
\hline COP of delivered solar energy & 7.9 & & (solar energy delivered)/(pump energy used) \\
\hline COP of total system & 3.5 & & (DHW energy delivered)/(energy used) \\
\hline
\end{tabular}

The COP of the heat pump and solar water heating systems in each operating mode is shown in Table 6:

Table 6. The COP in Each Mode

\begin{tabular}{lc}
\hline Operating Mode & Measured Average COP \\
\hline Space Heating & 3.6 \\
Space Cooling & 3.2 \\
Water Heating at $20^{\circ} \mathrm{C}$ & 2.0 \\
Water Heating at $45^{\circ} \mathrm{C}$ & 1.4 \\
Water Heating (average) & 1.55 \\
Solar water heating & 7.9 \\
Overall water heating & 3.5 \\
\hline
\end{tabular}




\subsection{Other Short-Term Measurements and Observations}

Infrared (IR) Imaging. We used an infrared (IR) camera to examine the insulated surfaces of the house to determine whether any insulation might be missing or impaired. Several small (about 1-2 $\mathrm{ft}^{2}$ ) areas in the ceiling were identified as locations where insulation batts in the attic had been moved during construction. Most of these areas were easily found in the attic and were repaired. One larger area (about $20 \mathrm{ft}^{2}$ ) was identified in the ceiling above the southeastern bedroom. It was located below the attic flooring and was not immediately repaired. The total amount of missing insulation was not a large percentage of the total area of the house. Repairing these areas was not expected to have a significant influence on energy use for heating and cooling, but it will be useful to correct these minor problems.

Fireplace Operation. Mr. Hathaway reported that he used his wood-burning fireplace during heating months to reduce electricity used for space heating. The fireplace was probably used nearly every evening during cold weather and more frequently on weekends. The fireplace uses outside air for combustion and has a fan to circulate room air around the firebox.

Propane Stove. The Hathaway's oven is electric and is included in this analysis. However, propane is used for their kitchen stove. We did not collect information on the propane consumption. The kitchen stove energy consumption is not included in this analysis.

\section{Long-Term Monitoring}

The short-term tests at the Hathaway house revealed much about the shell of the home and the operation of some of its subsystems (which will be discussed in section 6). Measuring the longterm performance of the whole house and its subsystems required the installation of a system that continuously monitors the changing conditions of the home such as energy use, PV energy production, temperatures, hot water use, etc. In September 2001, we installed sensors inside and outside the Hathaway house to monitor its performance. This monitoring continued through February 2004.

The energy consumed in a home is greatly affected by climate, thermostat settings, number of occupants, energy-use pattern of the occupants, the home design, and the equipment and appliance selection. The precise energy use of a home for a specific year and specific occupants cannot be predicted. Instead, predictions are based on typical weather data and typical occupant behavior. Monitored energy-use data reflect the influence of all of the factors listed above. Depending on the level of detail of the monitoring, some of these influences can be disaggregated.

This section of the report summarizes data collected from the home from September 2001 to June 2003.

\subsection{Monitoring System and Data Being Collected}

Data from the installed sensors are collected using a Campbell Scientific CR10X data logger. The data logger is equipped with a Campbell SDM-SW8A pulse multiplexer and a Campbell ATM25T thermocouple multiplexer. Further information on the hardware used is contained in 
Appendix 7.1. The system is connected by modem to a phone line in the home and data is downloaded daily.

In designing the data collection system, we focused on understanding the performance of the PV system, the solar water-heating system, the heat pump, and the main home appliances. The home was equipped with sensors for the 39 measurements listed in Table 7.

We had planned to directly measure the power production from the PV system on the AC side of the inverters. This measurement was not possible because of the wiring set-up. AC power from the PV system was not isolated in any of the wiring. We were measuring DC power from the PV system and applying the efficiency vs. power curve provided by Trace to estimate the AC power supplied by the PV system. 
Table 7. Data Monitored at the Hathaway House

Solar radiation $\left(\mathrm{W} / \mathrm{m}^{2}\right)$

In the plane of the collectors at the array on the house roof

Vertical south-facing

Energy (kWh)

Energy entering the home from the grid

Energy exiting the home to the grid

Heat-pump energy consumption

Clothes-dryer energy consumption

Clothes-washer energy consumption

Air-handler fan energy consumption

Kitchen-oven energy consumption (stove is propane)

Temperatures $\left({ }^{\circ} \mathrm{C}\right)$

Outside air temperature (from $\mathrm{T}$ and $\mathrm{RH}$ sensor)

Outside air temperature (thermocouple)

House PV array temperature

Garage PV array temperature

Attic air temperature

Second-floor air temperature

First-floor air temperature

Basement air temperature

Supply-air temperature

Cold-water temperature

Hot-water temperature

Temperature after the mixing valve

Temperature of glycol fluid to the solar water collector

Temperature of glycol fluid from the solar water collector

Temperature of water from tank to heat pump

Temperature of water from heat pump to tank

DC electrical measurements

Voltage of west house PV array (V)

DC current from west house PV array (A)

DC power from west house $\mathrm{PV}$ array (W)

DC current from east house PV array (A)

DC power from east house $P V$ array (W)

DC current from garage $\mathrm{PV}$ array $(\mathrm{A})$

DC power from garage $P V$ array $(\mathrm{W})$

Battery voltage $(\mathrm{V})$

Current to or from battery bank (A)

Current to well pump (A)

Other measurements

First-floor relative humidity

Outside relative humidity

Hot-water consumption (liters)

Solar water heater pump run time (minutes each hour) 


\subsection{Results from the Entire Monitoring Period}

The energy consumption by end use for the entire 30-month monitoring period is shown in Figure 13. Space conditioning (HP,space; HP,standby; and AHfan) accounted for about half of the total energy consumption. Water heating (HP,DHW and SolPumps) accounted for less than $10 \%$ of the total energy consumption. The clothes washer and refrigerator in the home were ENERGY STAR-rated, highly efficient appliances. Even with efficient appliances, the energy consumption from all the major appliances (Fridge, Washer, Dryer, and Oven) accounted for $17 \%$ of the total energy consumption. The stove was propane and was not included in this accounting.

Perhaps the most sobering result of this end-use accounting is the size of the "other" category. The energy consumption in the "other" category was calculated by subtracting every submetered category from the total house energy consumption. Despite submetering of the largest energy using appliances in the home, the "other" category was a whopping $23 \%$ of total energy consumption. This "other" category contained items such as lighting, computers, televisions and radios, toaster oven, microwave, hair dryers. Lighting was not submetered because it was distributed through many circuits in the home. However, this home already used compact fluorescent lights in every fixture, so the lighting energy should be quite low. The remainder of items in the "other" category was quite difficult for building scientists and researchers to reduce. As we continue to reduce space conditioning, water heating, and major appliance energy consumption, this "other" category will become an increasingly larger portion of the energy consumption pie.

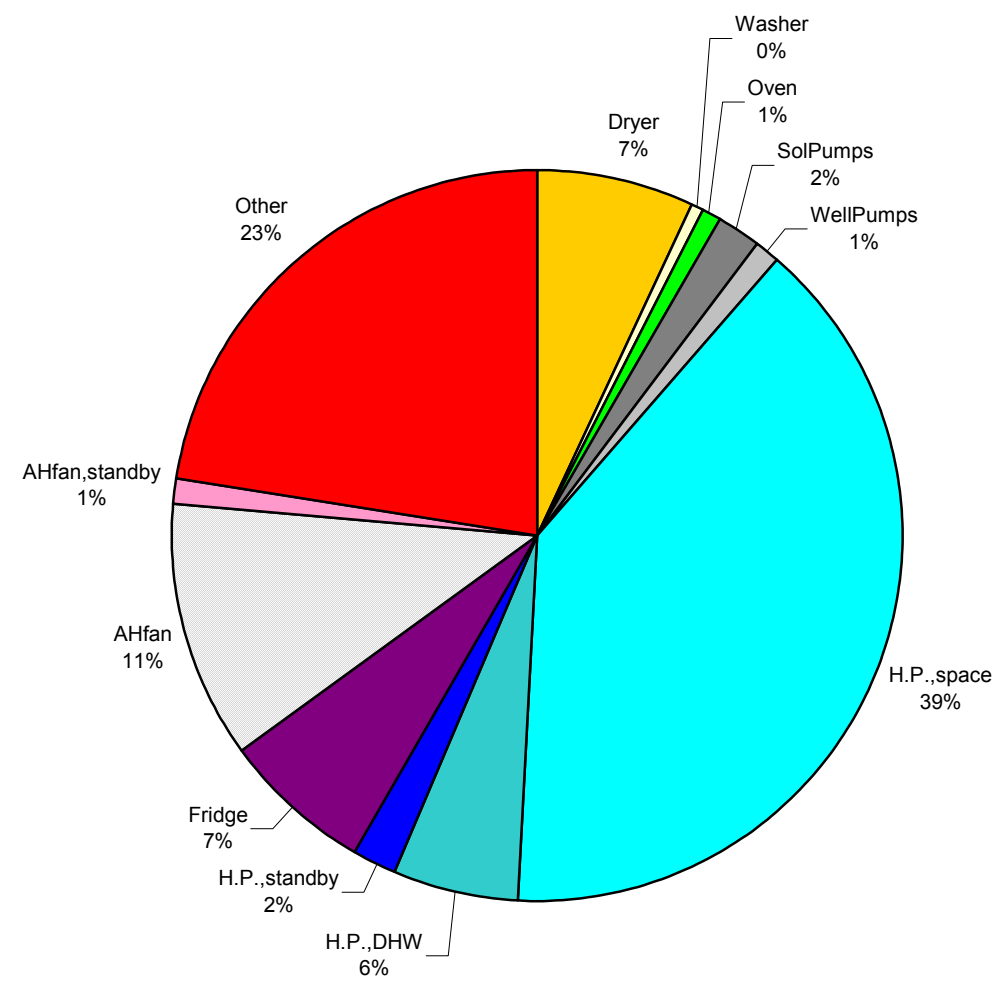

Figure 13. Total energy consumption by end use for the entire monitoring period - September 2001 to February 2004 
The monthly energy consumption by end use is shown in Figure 14. The substantial "other" category was relatively constant from month to month. Notice that the water-heating energy (HP, DHW) was several times larger in the first 3 months of data collecting than it was for the rest of the data-collection period. During those first 3 months, the water-heating mode of groundcoupled heat pump was switched on and off manually. It was switched on early in the morning and left on until all morning showering was completed. By the time it was switched back off, it had already heated the water in the single 80 -gallon storage tank. Because the storage tank water was warm at the beginning of the day, the solar collectors were effectively defeated. This problem was alleviated by using a timer to control the heat-pump water-heating mode. By adjusting the run time of the heat pump in water-heating mode, the family was able to assure sufficient hot water supply for morning showering without leaving the storage tank full of heated water at the beginning of the day. The change reduced water-heating energy consumption dramatically.

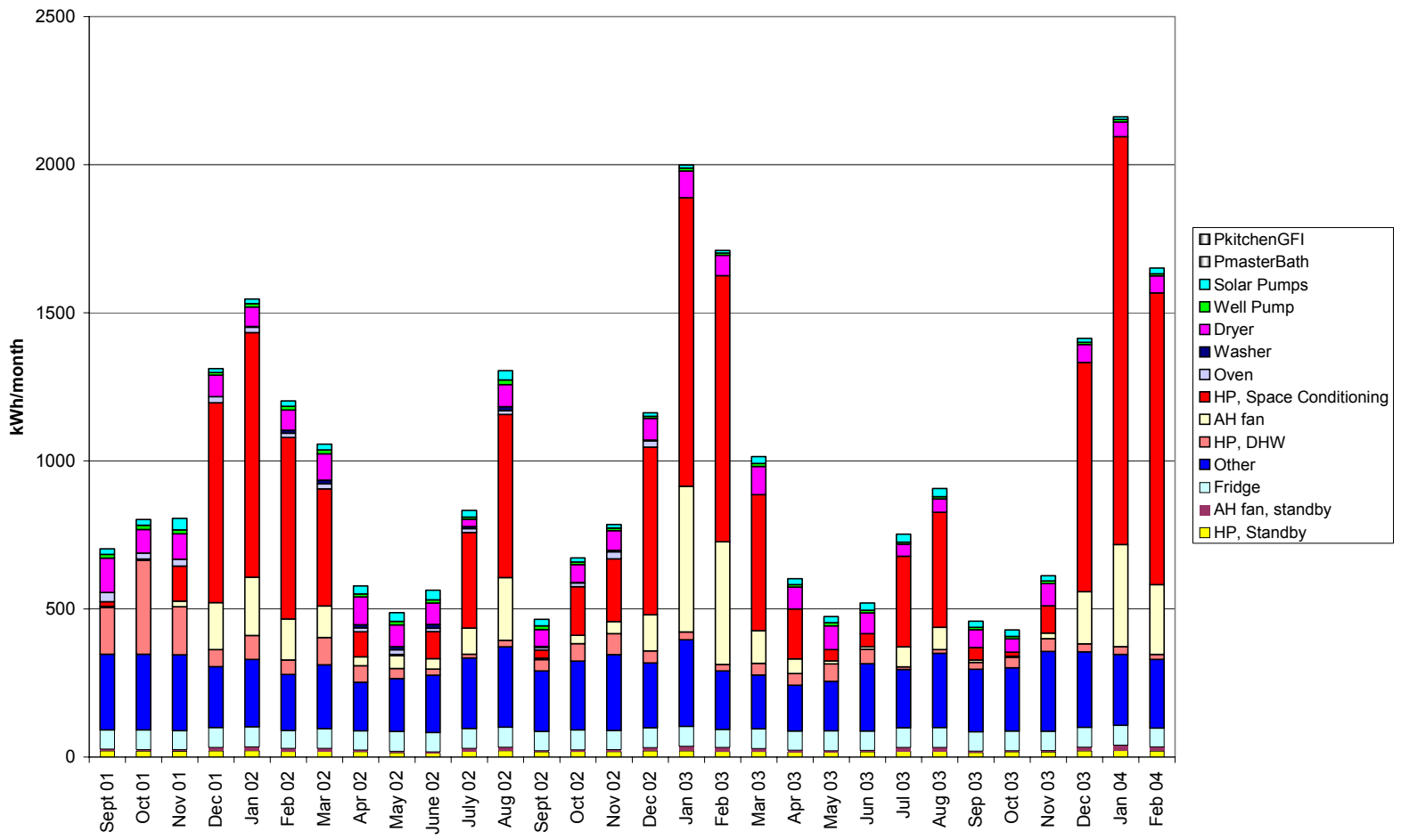

Figure 14. Monthly energy consumption by end use 
Figure 15 shows the AC electrical energy produced by the PV system. The PV system was oriented due solar south and tilted at about 49 degrees - near optimum for year-round energy production. The system was equipped with a battery back-up system that was kept charged to supply the home with power for essential needs during blackouts. The system was not equipped with a maximum power point tracker. With the exception of May 2002 (when there was a short interruption in service from one of the inverters) the PV system appeared to be operating as expected. Because there were fewer sunlight hours in the winter than the summer, the PV production was naturally lower in the winter. It is interesting to note how much the monthly PV power varied from year to year as a result of variations in the weather. For example, the PV system output in October 2002 was little more than half of the output in October 2001. In October 2002 much lower solar radiation levels were recorded in the plane of the collectors than in October 2001. (It was a cloudy October.) This should give pause to those who use TMY data to predict PV energy output. Without solar radiation measurements, low PV output like that seen in October 2002 could be misinterpreted as a problem with the system.

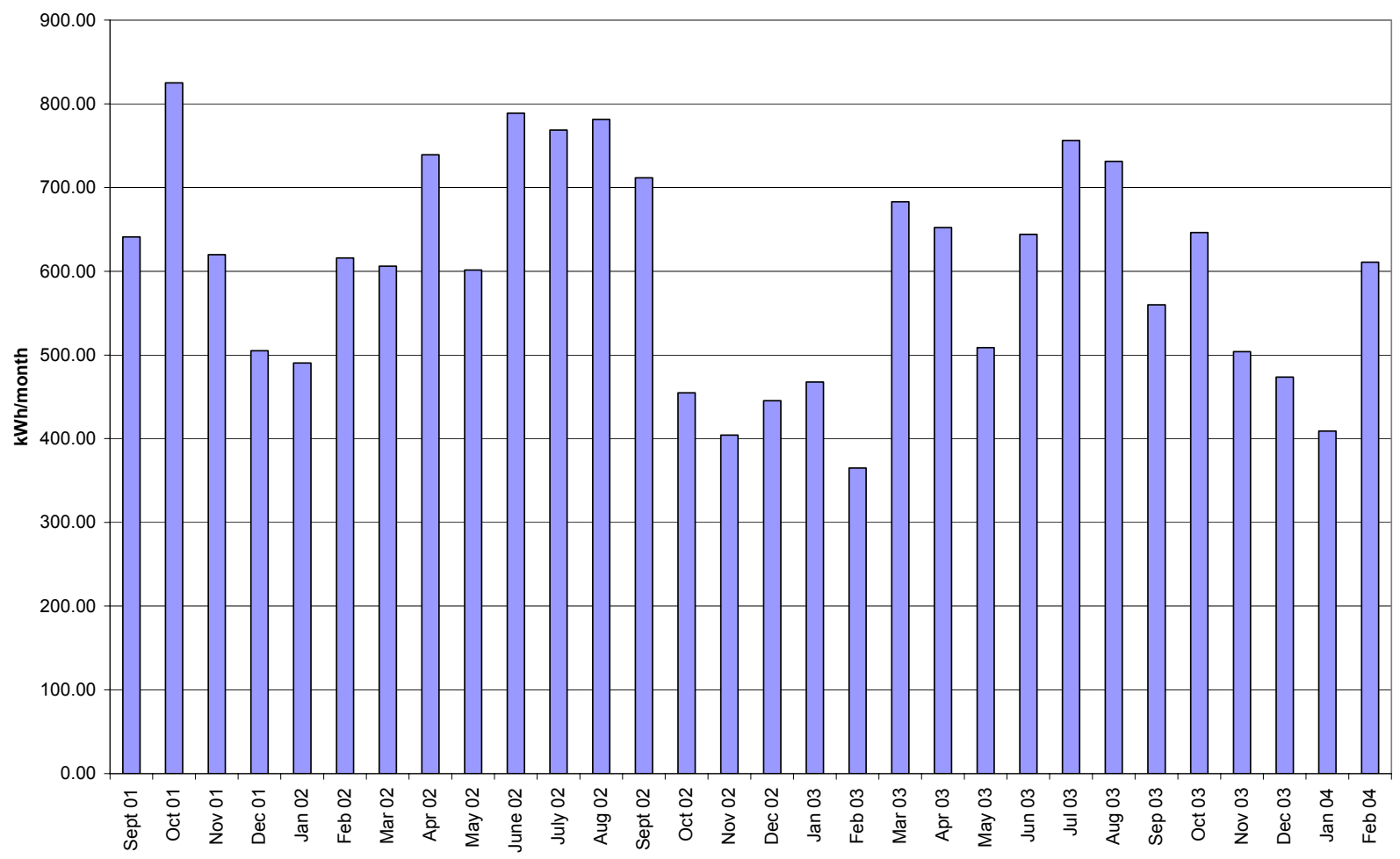

Figure 15. Monthly electrical energy (AC) produced by the PV system 
The total monthly energy consumption minus the monthly PV AC energy production yielded the net monthly electrical energy purchased, shown in Figure 16. During 8 months of the datacollection period the home produced more electricity than it consumed. These months occurred in the spring and fall "swing seasons" when the outdoor conditions are near the inside temperature setpoint and little space-conditioning energy was required to maintain comfort. In the summer and winter, the space-conditioning energy needs overwhelmed the PV production, and the home required more energy than it produced. The PV system appeared to be able to meet the needs of the auxiliary water heating, the major appliances, and the "other" category, but not the entire space-conditioning load. Because the space-conditioning equipment was already nearly the most efficient electrical equipment available, this indicated that it may be a good idea to look at more efficient shell designs, a better air-distribution system, or a larger PV array if we wish to reach zero net annual electrical energy consumption. We will revisit this topic in the section on building energy simulation.

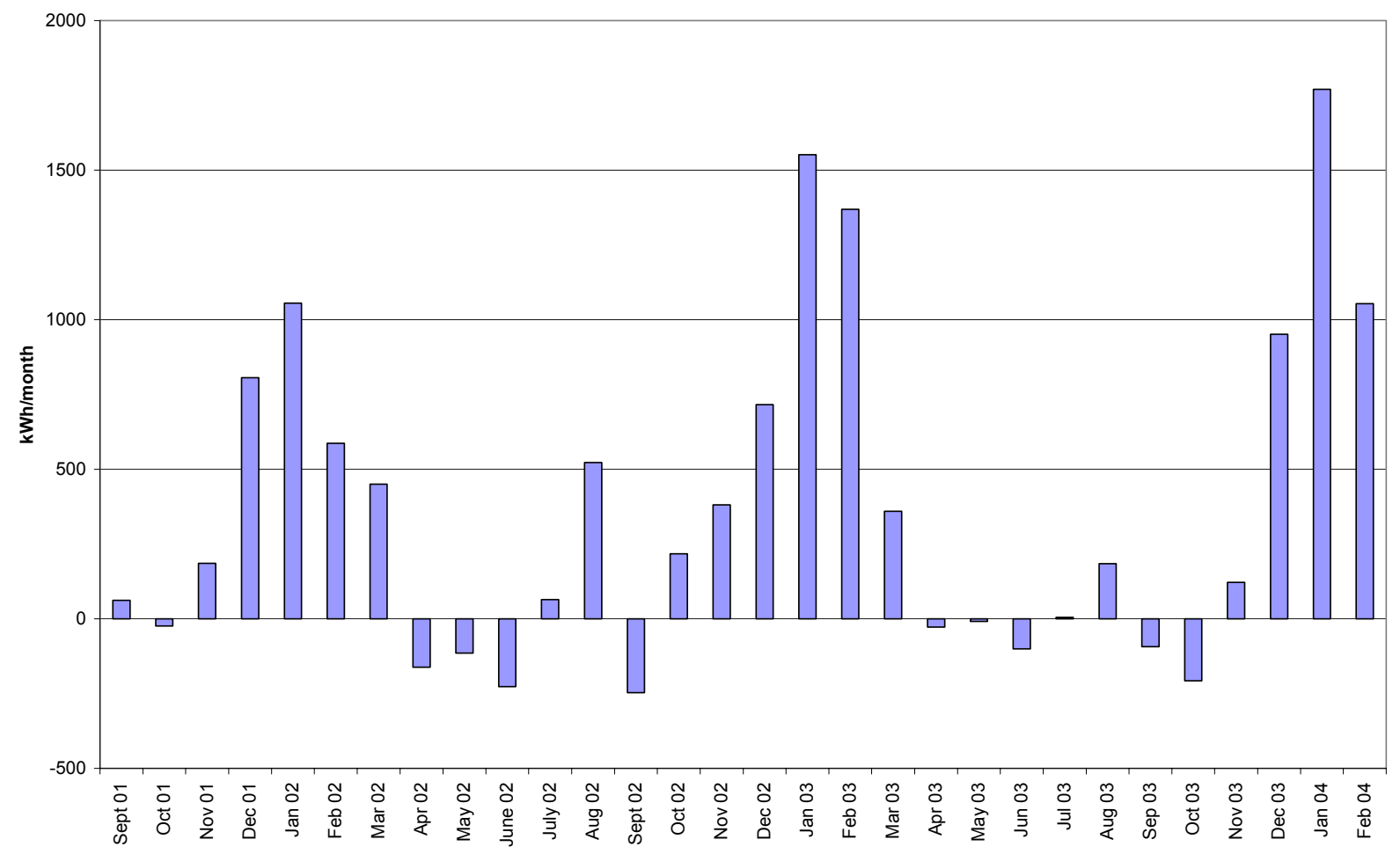

Figure 16. Monthly net electrical energy bought 
The Hathaway house had three PV arrays employing two different technologies. The two arrays on the roof of the homes were both composed of building-integrated peel-and-stick amorphous silicon modules from Uni-Solar. The array on the garage roof was composed of rack-mounted monocrystalline panels from BP Solar. The maximum power point voltage behaved differently with temperature for these two different technologies, but the Hathaway array was operated at a constant voltage. In addition, the difference in physical characteristics of the arrays may have shed snow differently. Therefore, we would expect the outputs from the three arrays, each nominally rated at $2 \mathrm{~kW}$, to differ. Figure 17 shows the monthly DC output from each array. Although they were nearly identical, the energy output from the east and west arrays on the home differed by an average of about $10 \%$ with the east array consistently outperforming the west array. We have no ready explanation for this difference other than variation in module-tomodule output manufacturing variability. The garage-array energy output was usually less, but sometimes more than the output from the home arrays. This variation was likely a result of the variation of maximum power-point voltage with temperature. In general, for the Hathaway house operating voltage of about 53 to 54 volts, the monocrystalline array performed better with respect to the amorphous arrays during months when the average outdoor temperature was low.

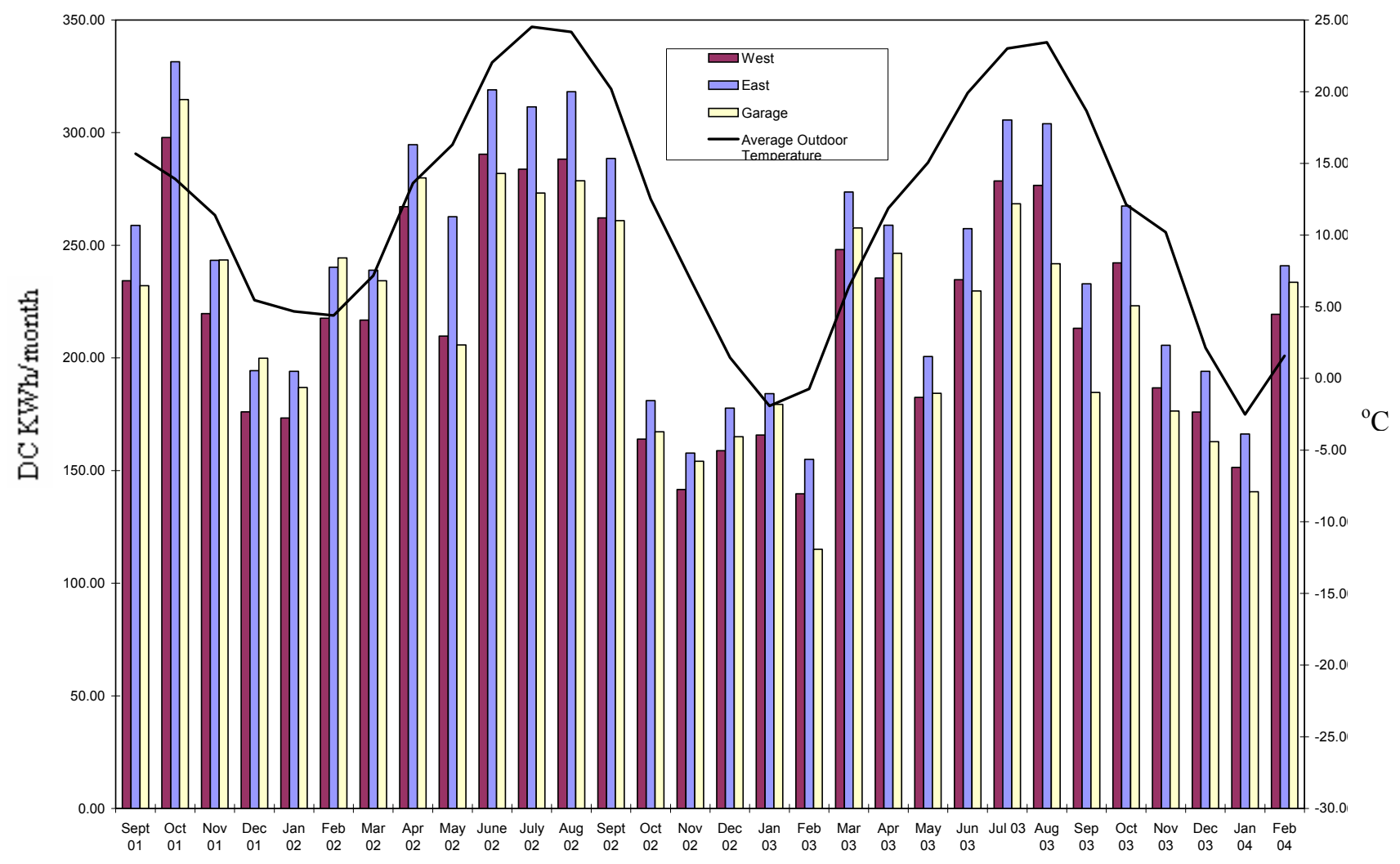

Figure 17. Monthly electrical energy (DC) produced by each of the three PV arrays and average outdoor temperature (west and east are the arrays on the roof of the home) 


\subsection{Results from the Calendar Year 2002 and 2003}

The two arrays summed to a nominal $6 \mathrm{~kW}$ of rated capacity. The average daily power production from the array in 2002 was about $20.3 \mathrm{kWh} /$ day. This equates to an equivalent of about 3.4 equivalent full sun hours per day.

The average daily power production from the array in 2003 was about $19.2 \mathrm{kWh} /$ day. This equated to an equivalent of about 3.2 equivalent full sun hours per day.

A home that is designed to have net zero net energy consumption for standard occupants under TMY weather data may not have zero net energy consumption with any specific occupants on any given year. Also, a home that achieves zero net energy consumption in one year, may not achieve it in other years even with the same occupants as a result of to year-to-year variations in available solar radiation. The Hathaway house design did not use rigorous energy simulation and optimization to attempt to achieve zero net energy. The approach employed by the builder and the homeowner was empirically based on past experience. The home did, however, achieve impressive efficiency and a very low net energy consumption. The total PV production and net purchased energy for calendar years 2002 and 2003 are shown in Figure 18. During 2002 the home produced an outstanding $70 \%$ of the total electrical energy used in the home.

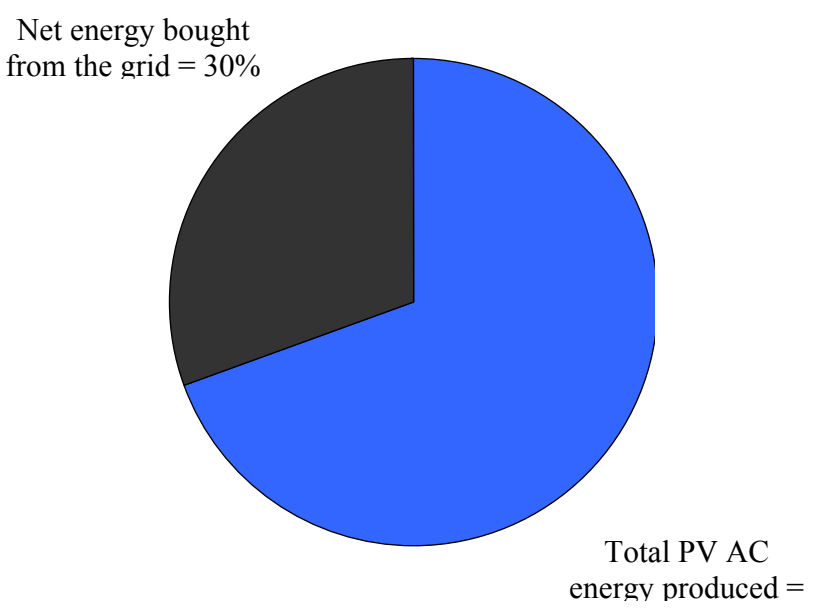

2002 Calendar Year

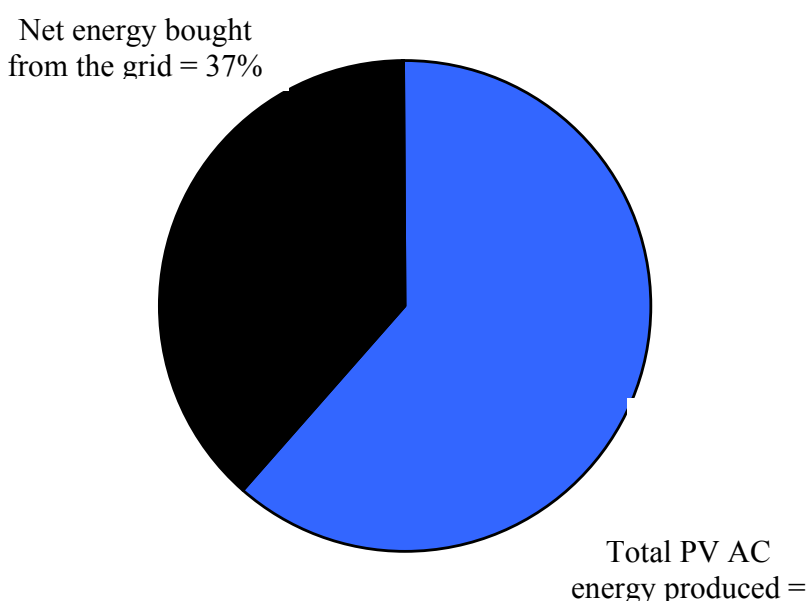

2003 Calendar Year

Figure 18. Energy produced by the PV system and net energy bought from the grid for 2002 and 2003 


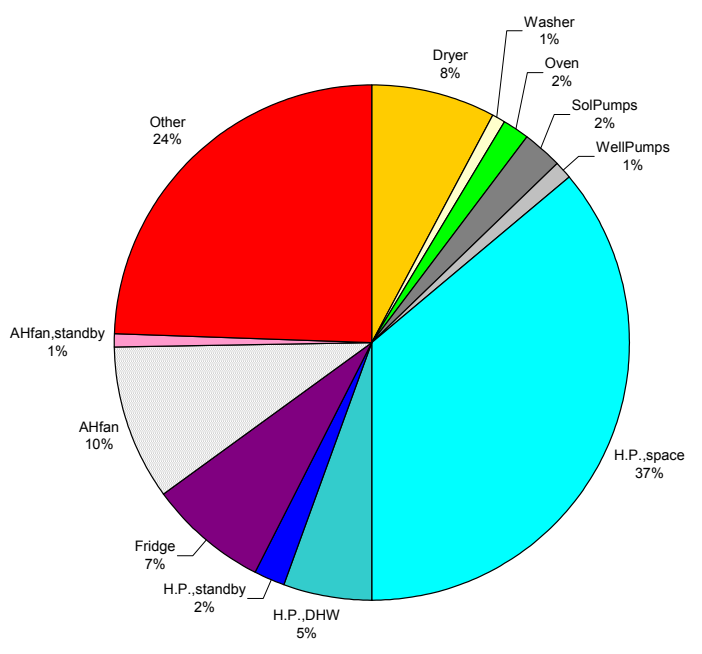

2002 Calendar Year

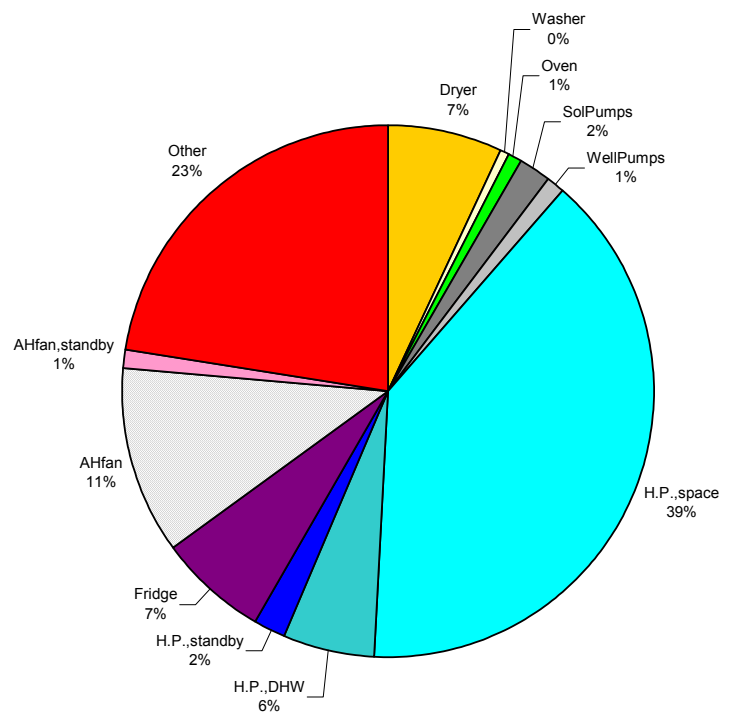

2003 Calendar Year

Figure 19. End use percentages for 2002 and 2003

Figure 19 shows the percentage of energy used for each monitored end use in the 2002 and 2003 calendar years. Although there are some very minor shifts, the relative end use consumption was nearly identical for the two time periods.

\subsection{Average Hourly Profiles}

Hourly profiles chart the monthly average of a measurement for each hour of the day. They provide insight into the average variation of a quantity over the course of a day and the shift in daily profile from month to month. The hourly profiles for selected temperatures, energy uses, hot water use, and solar radiation are shown in Figures 20 to 31. 


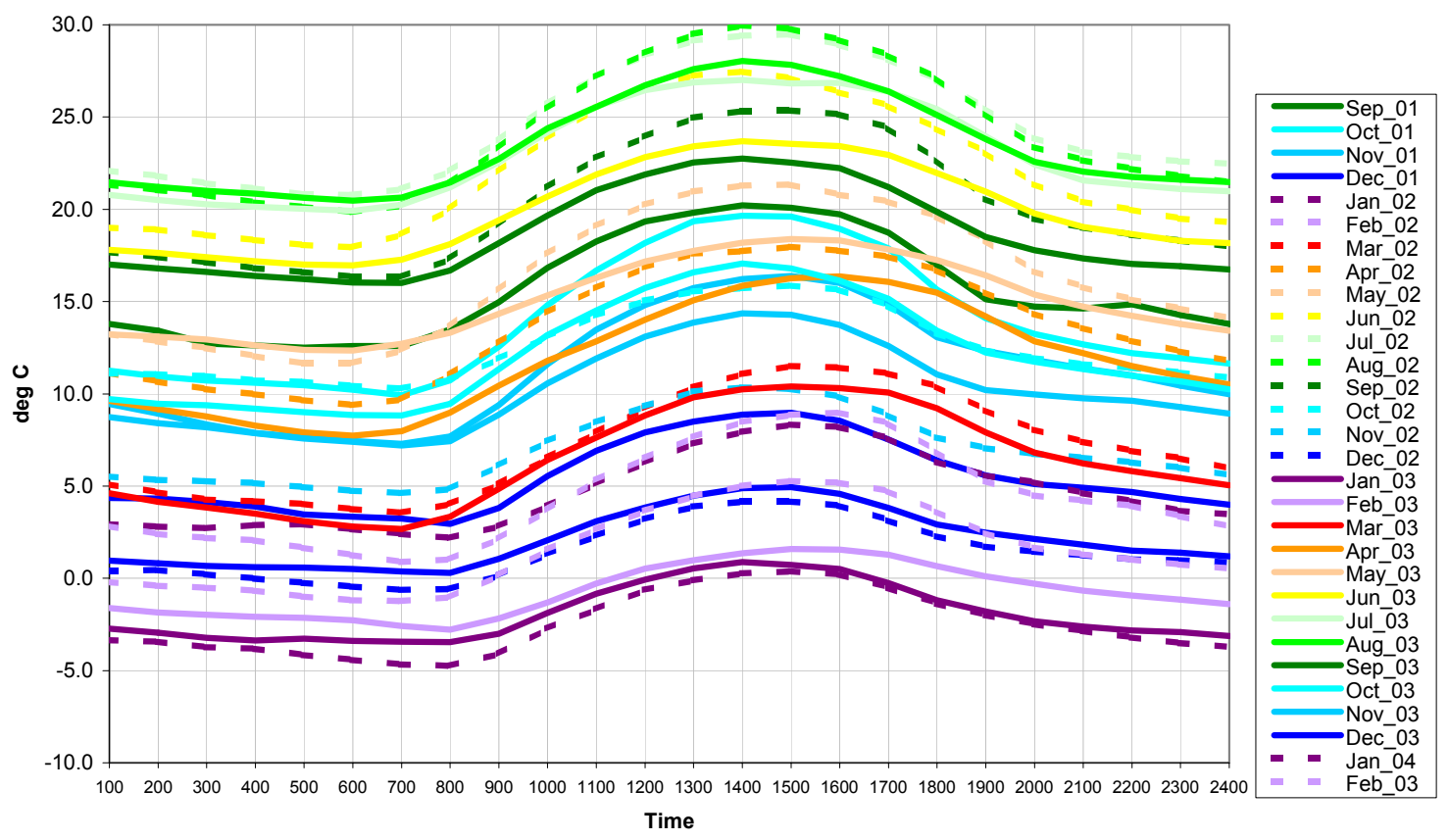

Figure 20. Outdoor temperature average hourly profile

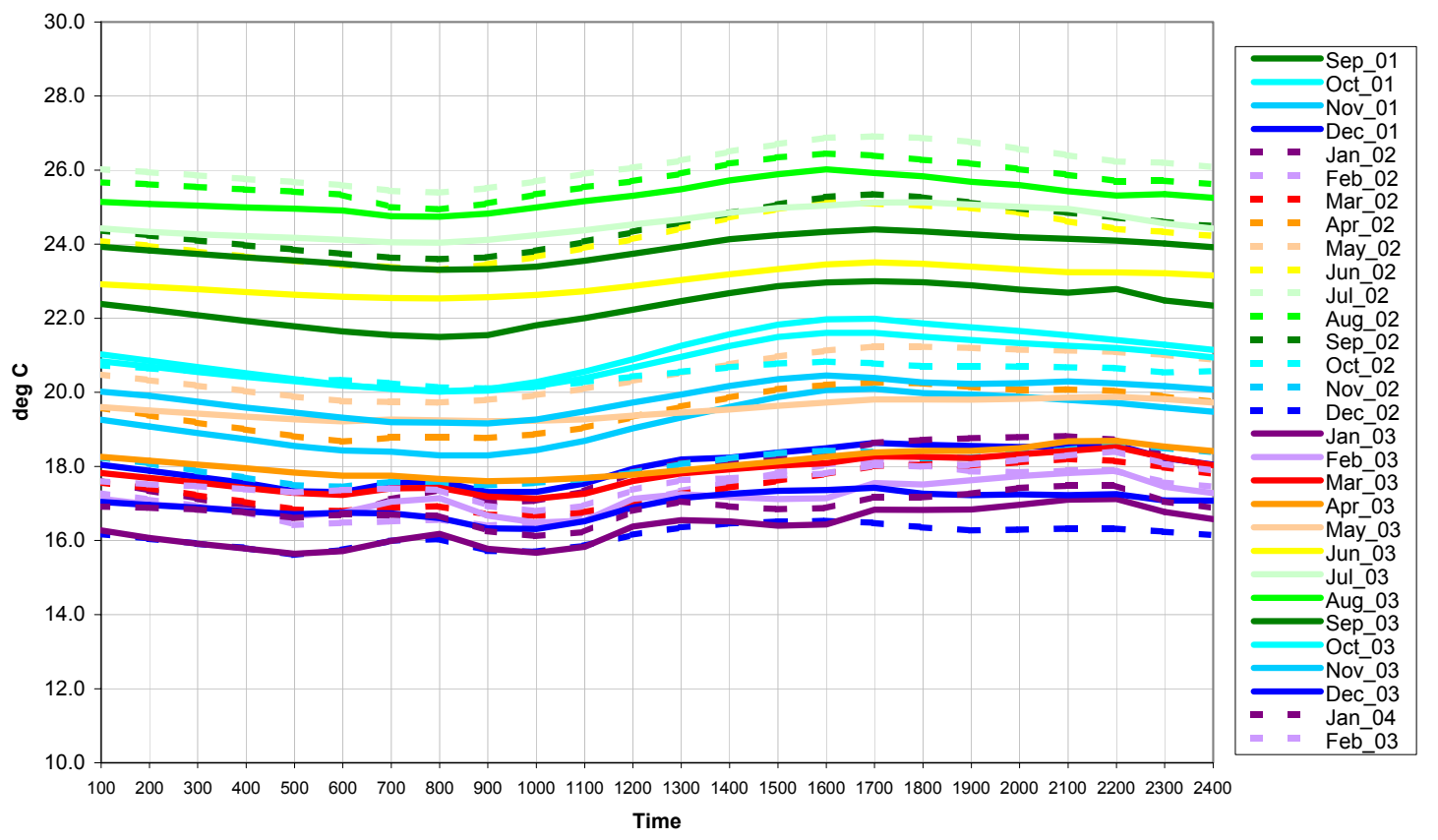

Figure 21. First-floor indoor temperature average hourly profile 


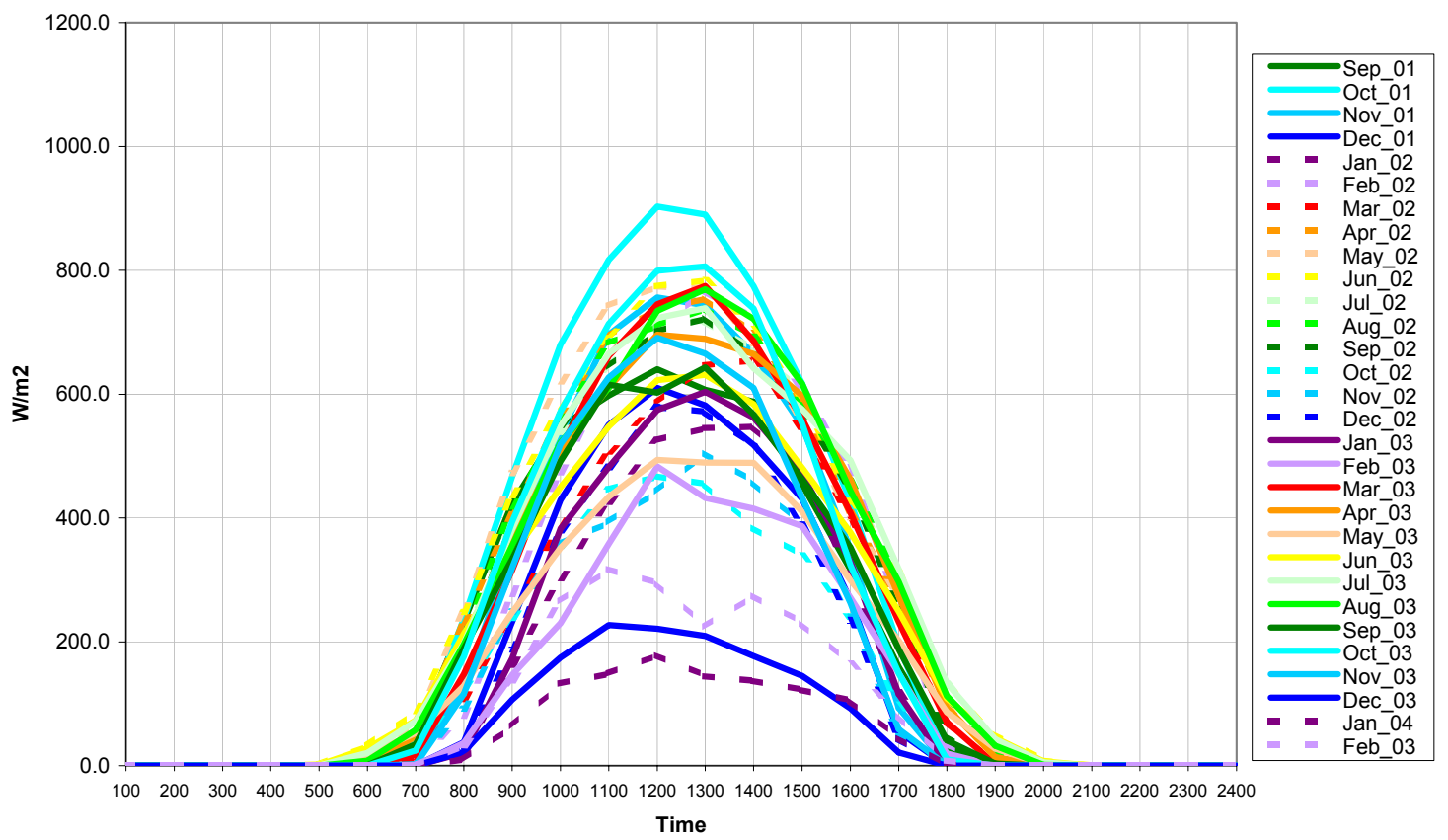

Figure 22. Irradiance in the plane of the collector average hourly profile

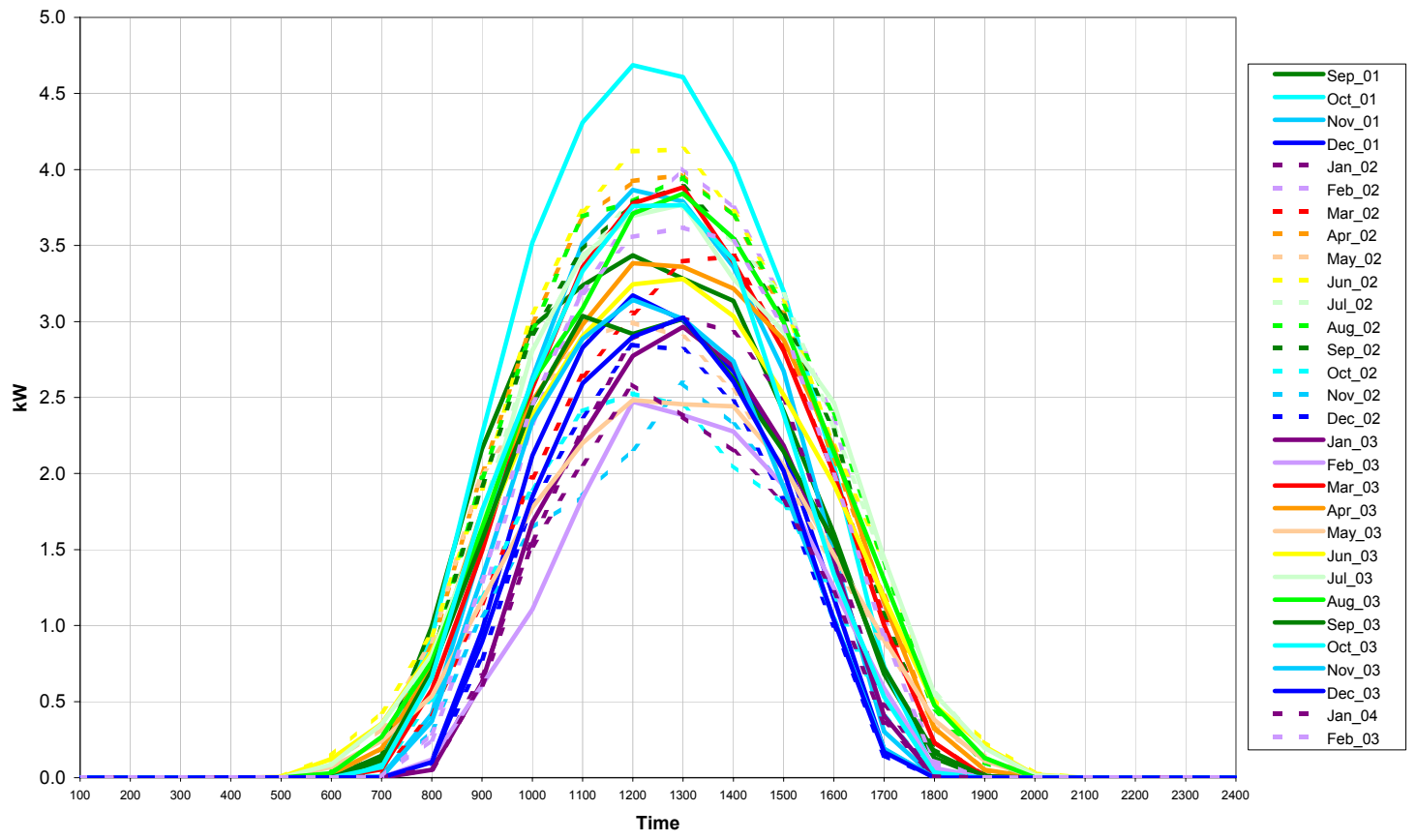

Figure 23. DC power from the PV system average hourly profile 

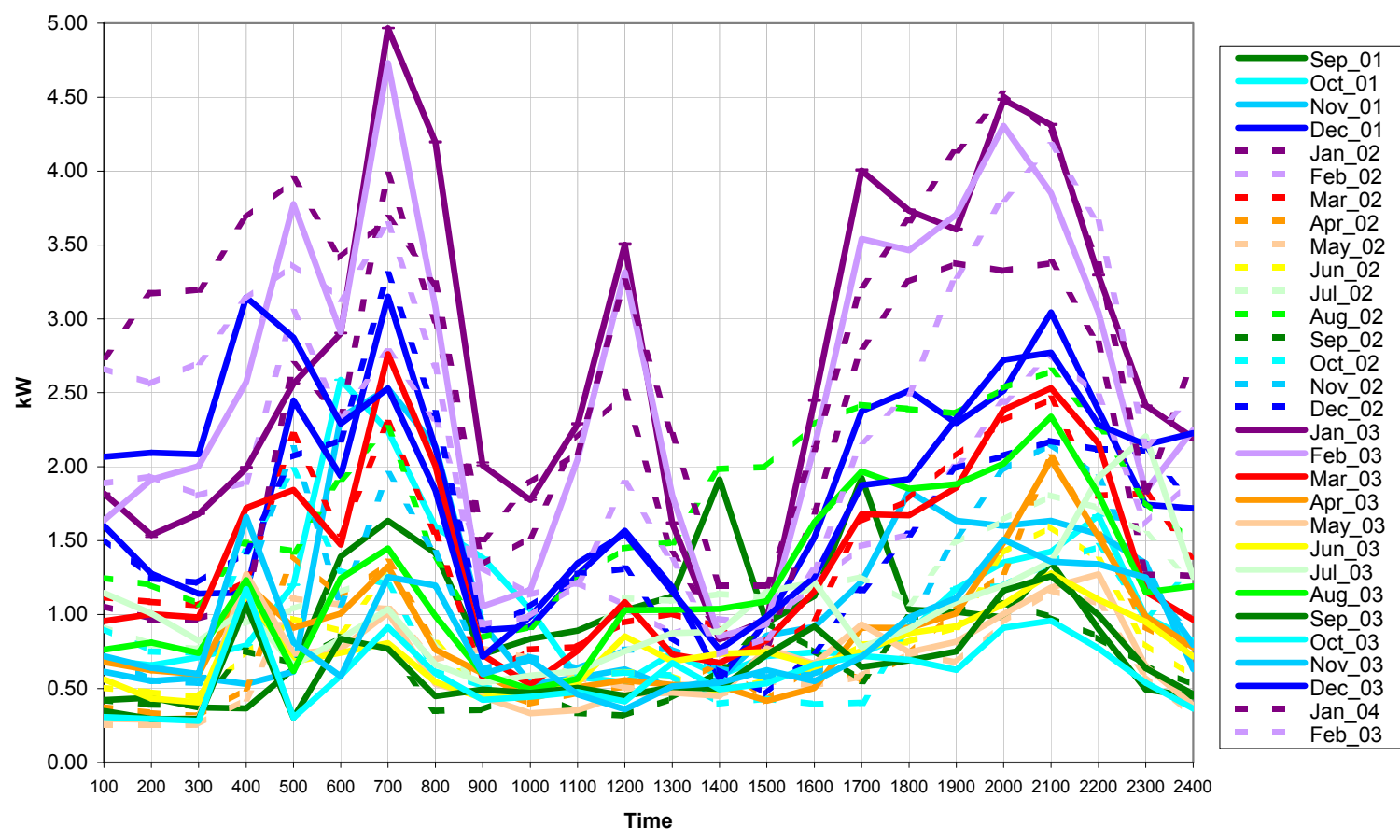

Figure 24. Total power use average hourly profile

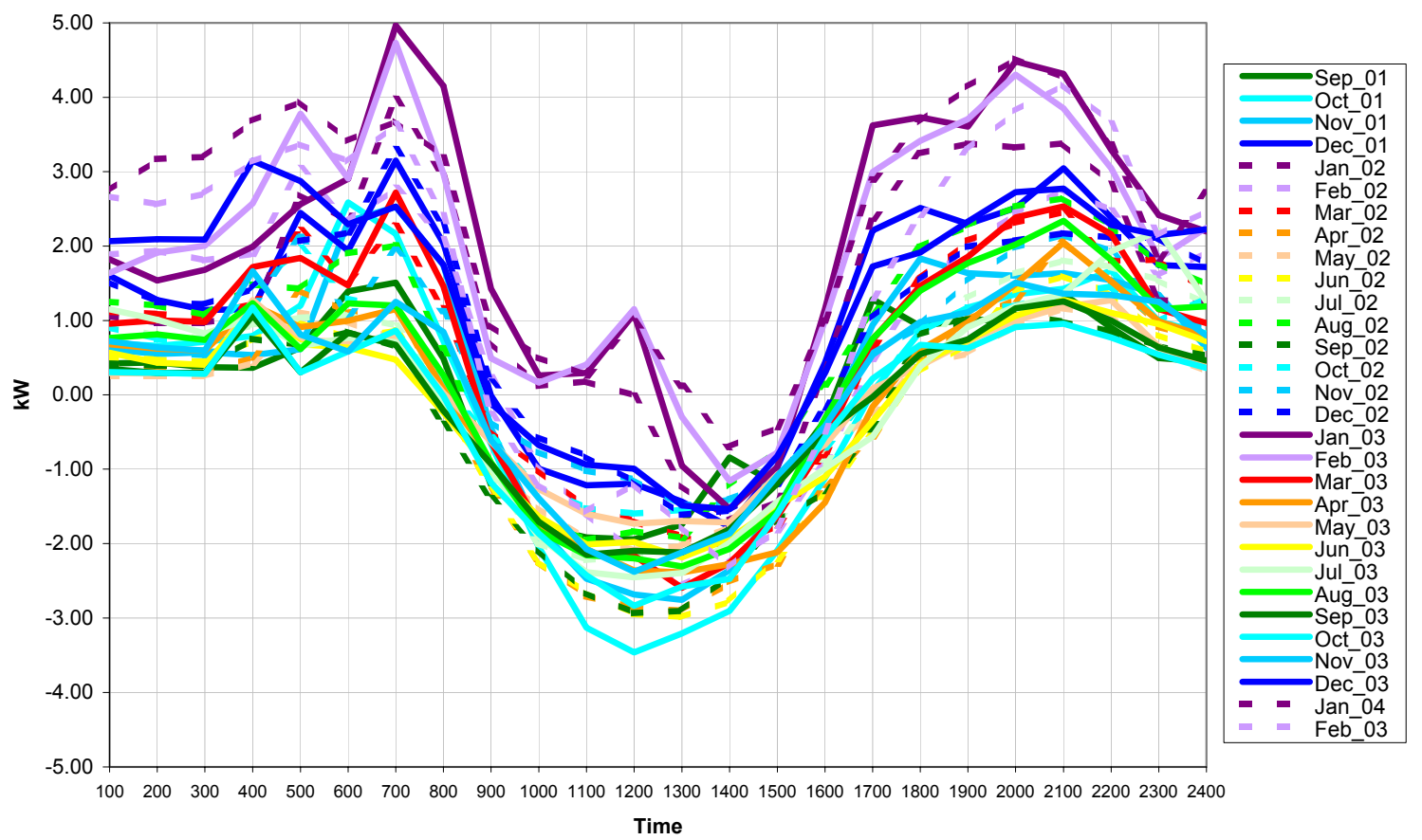

Figure 25. Net power bought from the grid average hourly profile 

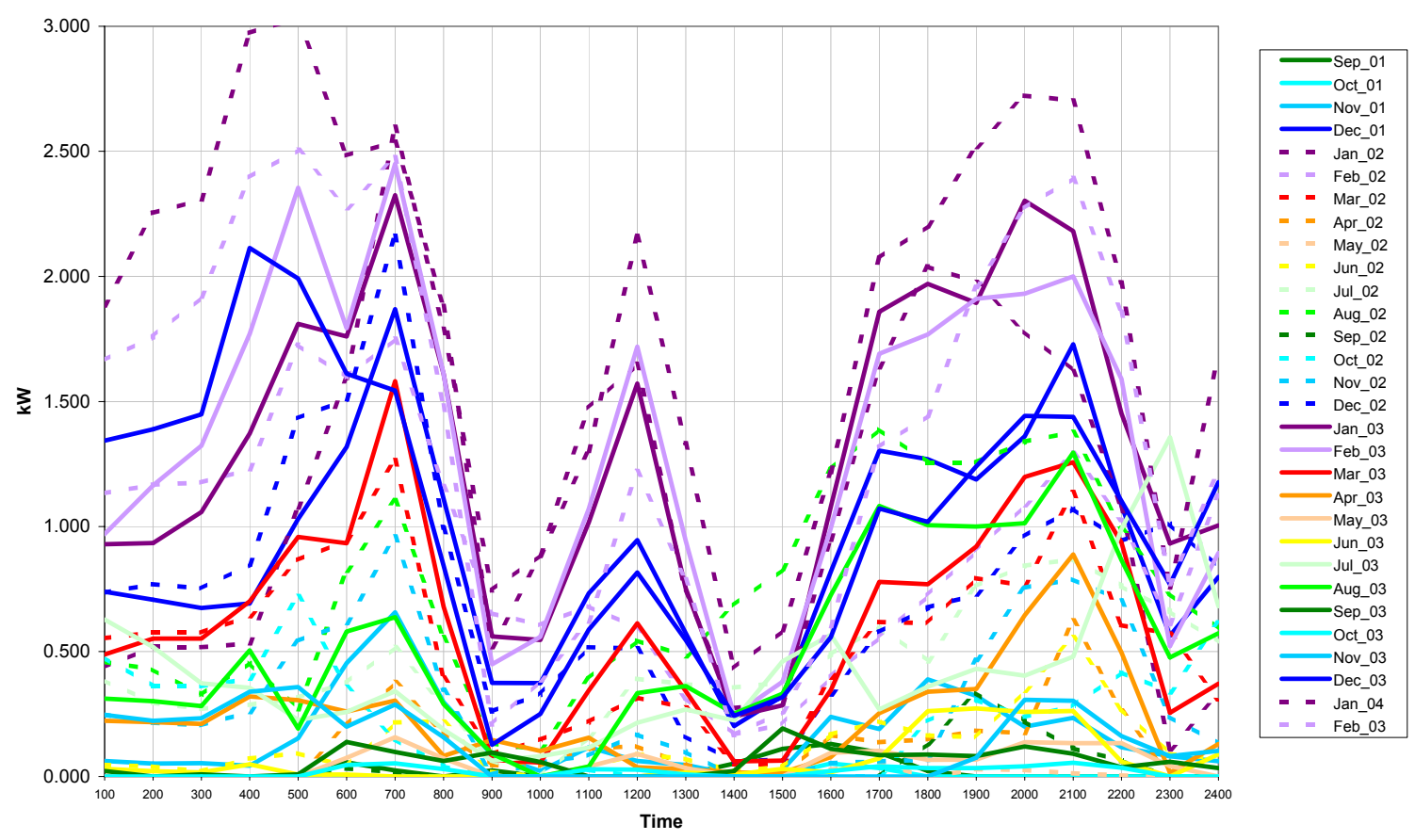

Figure 26. Power used for space conditioning average hourly profile

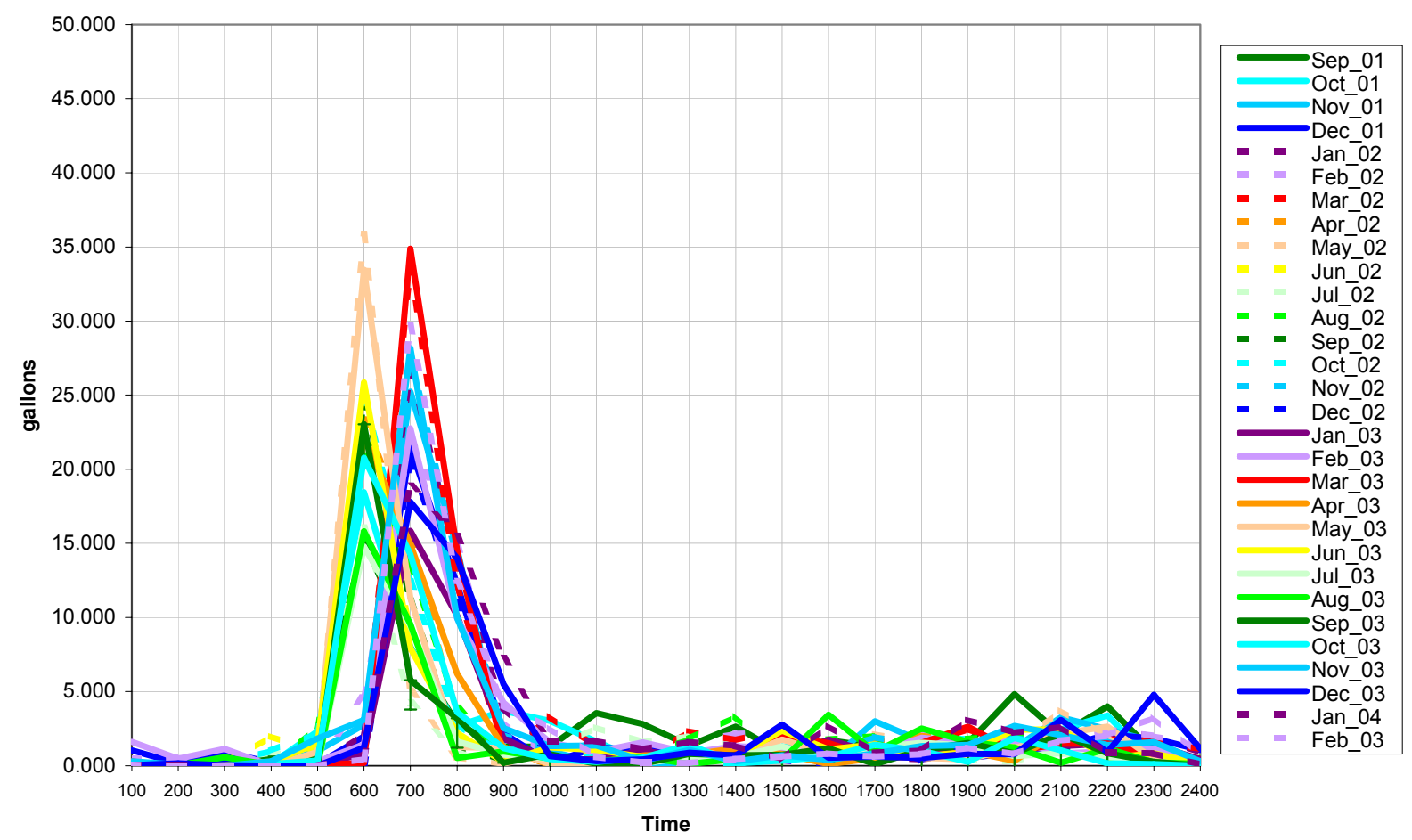

Figure 27. Heat-pump power used for water-heating average hourly profile 


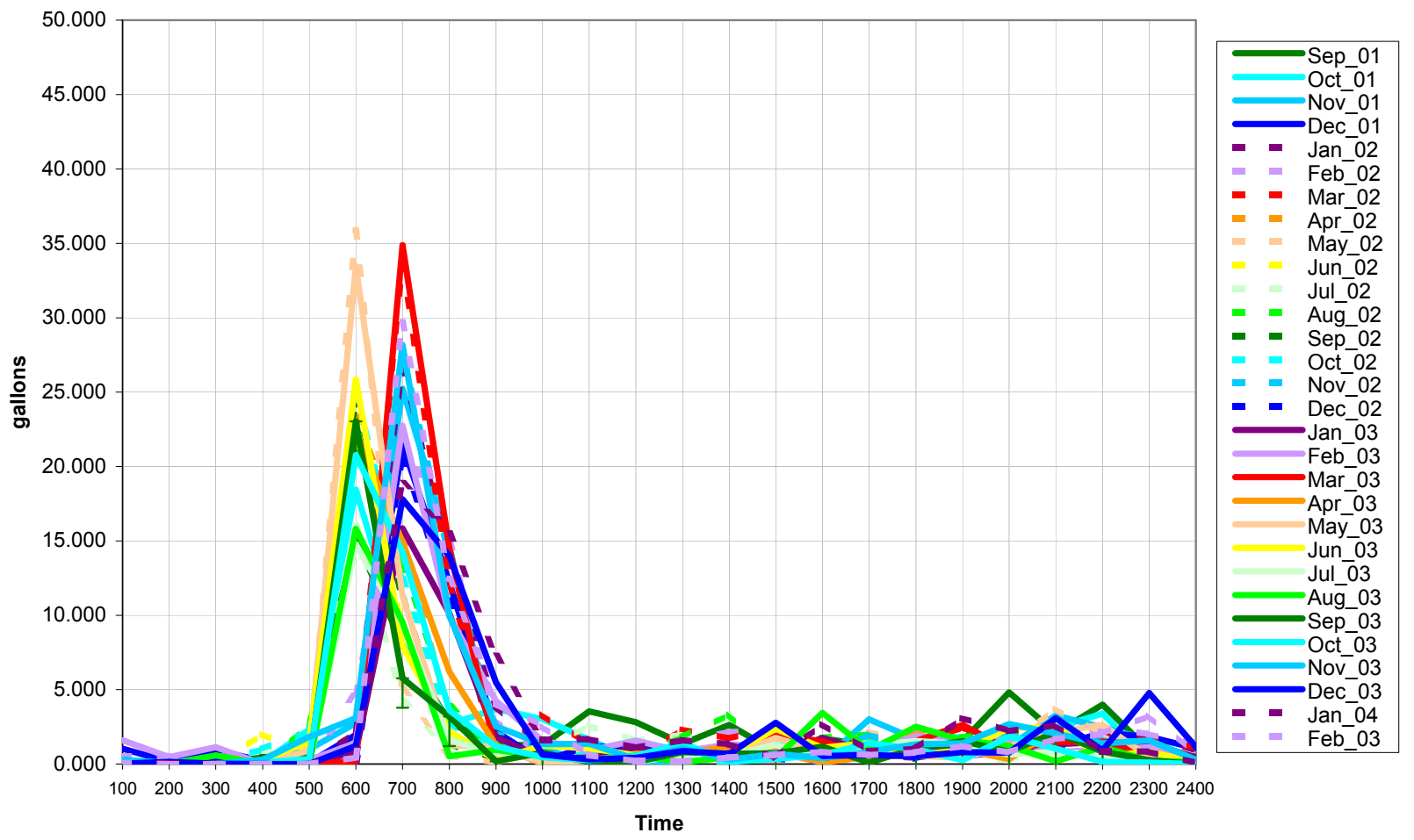

Figure 28. Hot-water draw average hourly profile

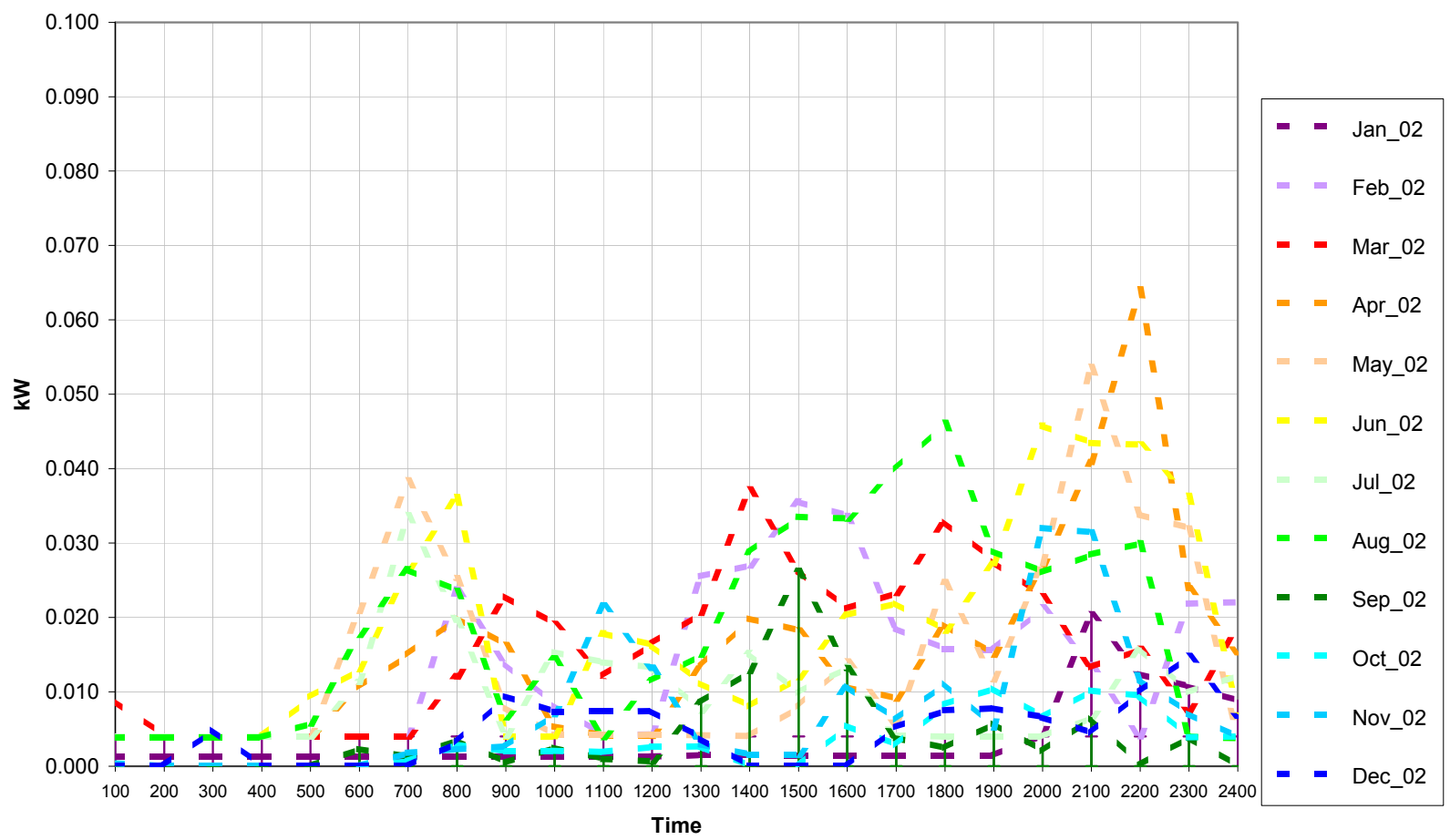

Figure 29. Clothes washer power use average hourly profile 

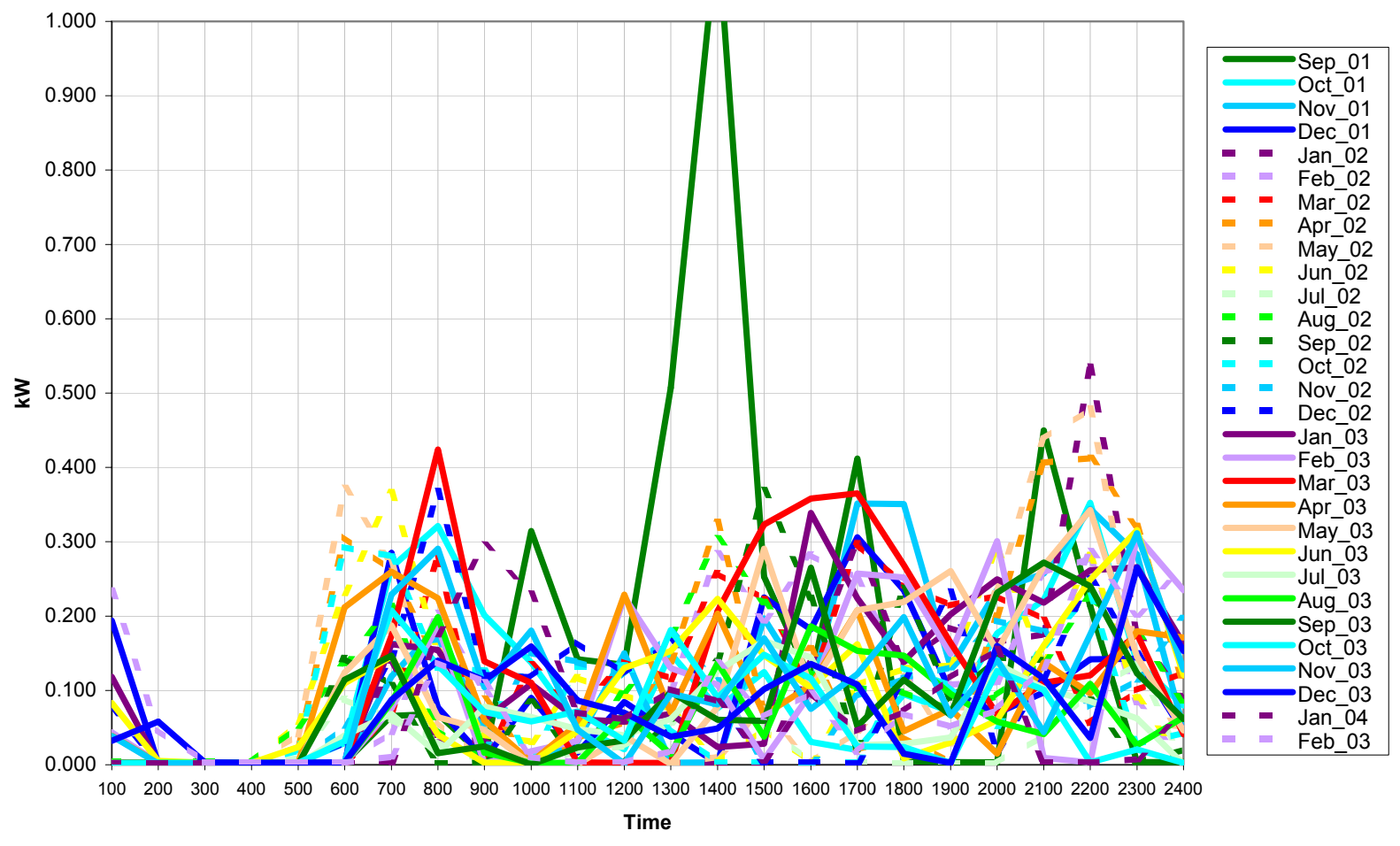

Figure 30. Clothes dryer power use average hourly profile

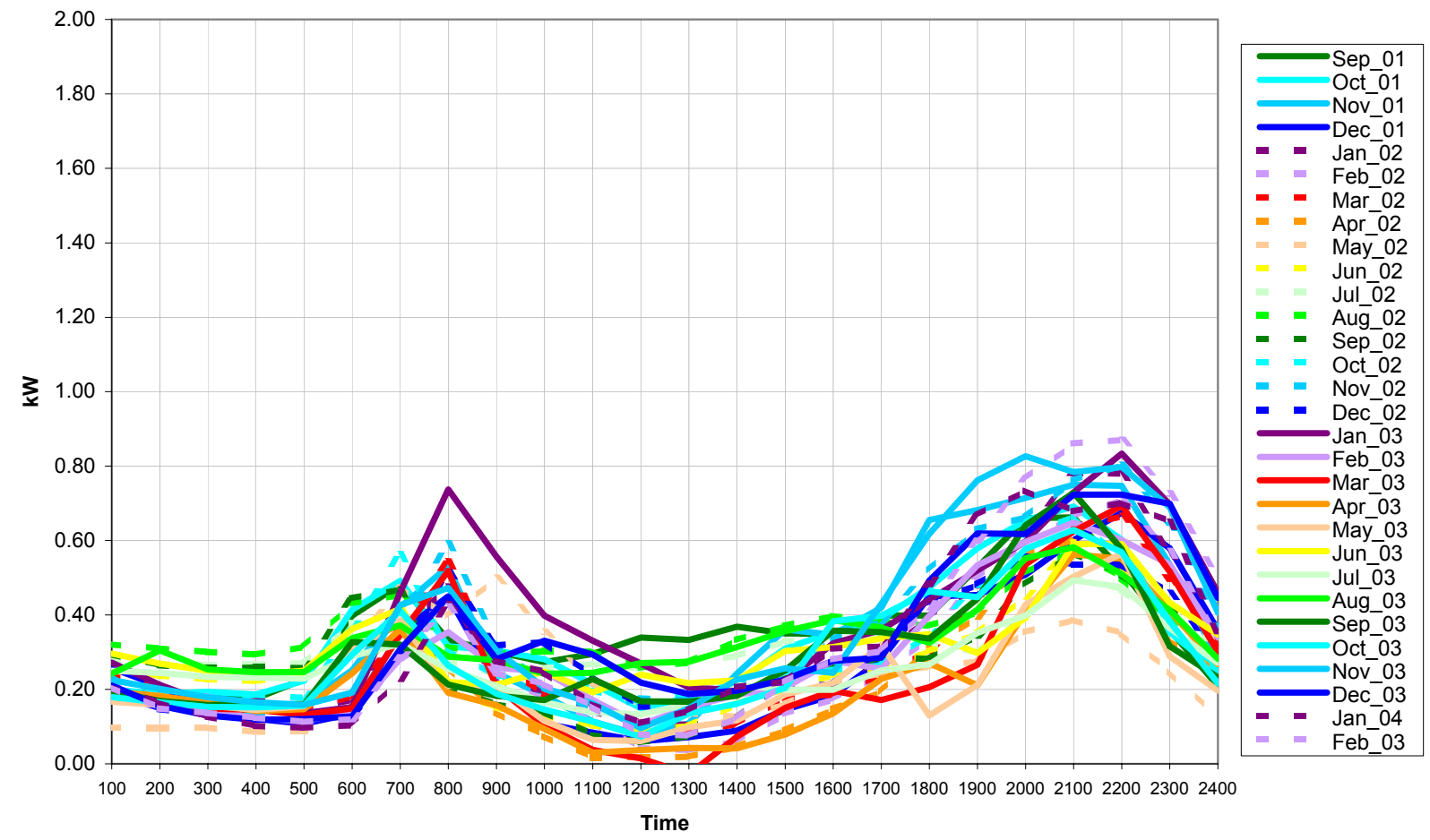

Figure 31. "Other" power use average hourly profile 
Some interesting observations from the hourly profile data are listed below:

- The net power bought from the grid (Figure 25) showed a marked dip in the middle of the day. This was a result of the contribution from the PV system, which peaked midday (Figure 23). Many homes of this type could reduce the overall peak requirements on the energy grid, which would be a real benefit for the electrical utility.

- The power use in the "other" category (Figure 31) almost never went to zero. At 4:00 am, the home was still consuming and average of between 100 and 300 watts.

- The average indoor temperature (Figure 21 ) varied seasonally from a high of nearly $80^{\circ} \mathrm{F}$ in July and August to a low of around $62^{\circ} \mathrm{F}$ in January and February. These January and February temperatures were well below those typically found in homes.

- Most hot water (Figure 28) was used in the early morning hours.

\section{Simulated Energy Performance}

We modeled the Hathaway house energy performance using DOE2 simulation software. ${ }^{14}$ DOE2 is a widely used and accepted building energy-analysis program that was developed by the U.S. Department of Energy's Lawrence Berkeley National Laboratory. DOE2 has been subjected to the BESTEST software validation procedure. ${ }^{15}{ }^{16}$ The program uses a virtual model of the home based on the actual materials, size, shape, orientation, shading, mechanical systems, etc., of the test home. It subjects this virtual model to hourly weather data for the location of the home to calculate the hourly energy consumption of the home. This hourly data is summed to give the annual energy consumption of the home. The energy consumption is then compared to a other virtual models, called the "base cases," that closely resembles the test home, but do not have all the energy-saving features of the test home. The different base cases used for comparison to the Hathaway house are discussed in section 6.3. Details on the modeling approach used by NREL in the Building America program can be found in reference. ${ }^{1}$ Images of the DOE2 model are shown in Figure 32.
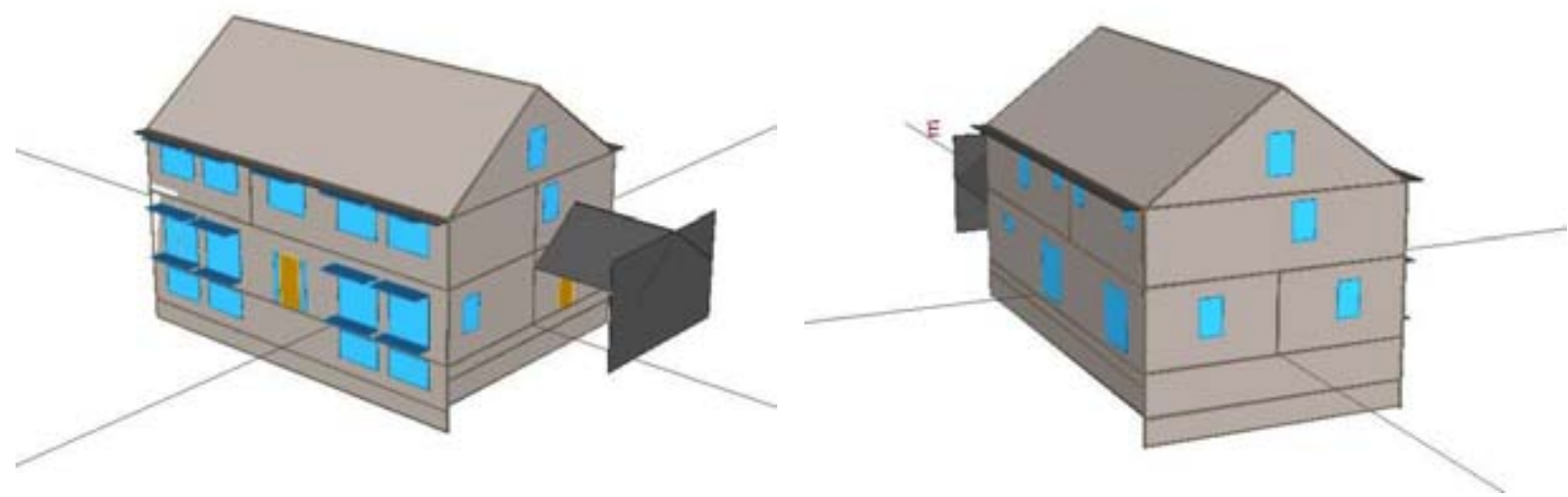

Figure 32. DOE2 model of the Hathaway House, the dark area simulates the shading of the home by the garage and breezeway roof 


\subsection{Improving Accuracy: Modeling Specific Systems}

The residential system models available in DOE2 do not include a direct-expansion, groundcoupled heat pump, solar water heating system, or PV system as is found in the Hathaway house. The long-term monitored data, therefore, was essential in characterizing the performance of these systems.

The measured COPs of the heat pump in heating and cooling modes discussed in section 3.2 were used to characterize the performance of the heat pump in the DOE2 model. While this performance level of the heat pump is a function of the weather experienced during the monitored period, the overall average measured system performance was used in place of a component-based simulation within the model. Although this approach was a simplification, it allowed us to use the measured COP in the simulation.

For water heating, a simplified approach based on the overall average COP of the solar/heat pump system (calculated in section 3.2) was implemented in the DOE2 model. The actual measured energy contribution of the PV system for calendar year 2002 was incorporated into the whole-house energy analysis independently of the DOE2 analysis. Note that the DOE2 analysis was driven using TMY2 weather data, but the PV performance is based on the actual 2002 weather.

\subsection{Building Confidence: Comparing Monitored Data and Simulation Results}

The Building America prototype simulation model is based on the description of the house "asbuilt" along with standardized behavior and controls as defined in the Building America Performance Analysis Procedures. ${ }^{17}$ The model of the physical building attempts to be as true as possible to what was actually built and installed in the prototype house. The use of the building, however, and the energy consumption associated with it, must rely on established assumptions regarding average occupant behavior and typical hourly weather data.

Monitored Data and the Building America Prototype. There is no reason to expect that the occupants of any particular house will behave according to the Building America benchmark operating conditions. While the mean behavior of the occupants (in the better sense of the adjective) is expected to be close to the behavior assumed for Building America, behavior may vary to a large degree. Comparing the monitored data (largely influenced by actual behavior) and simulation results (largely driven by assumed behavior) was, therefore, mainly a comparison of the actual occupants to the "assumed" occupants.

Figure 33 below shows a monthly comparison of total electricity used at the Hathaway house in the year 2002 (not accounting for PV generation) and the total electric use of the Hathaway prototype simulation model based on TMY2 weather and standard occupant behavior. The model predicts that the house would use $62 \%$ more electricity than it actually used for the annual period. 


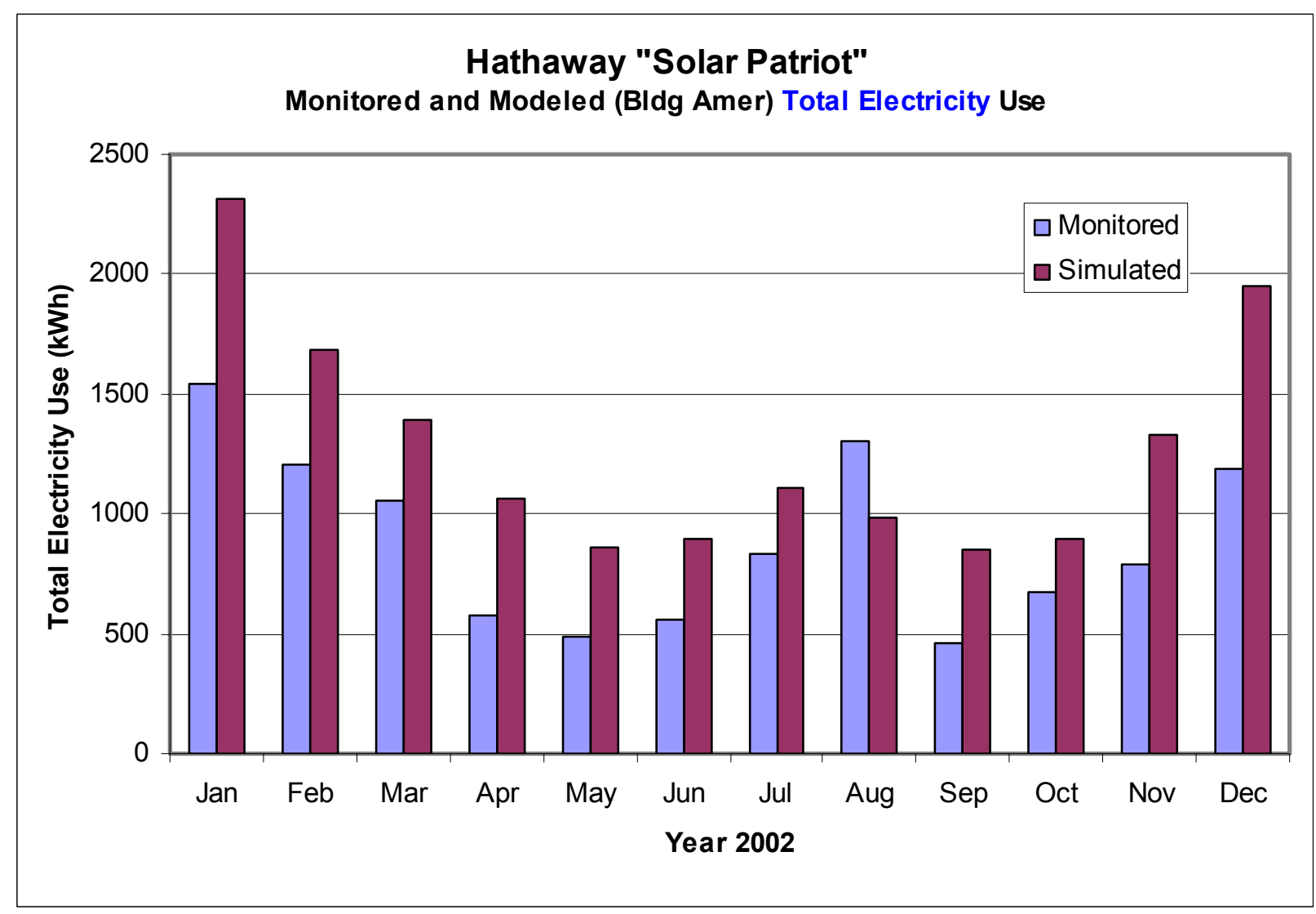

Figure 33. Monitored data vs. simulation results for total energy use using Building America assumptions and TMY2 data

The model predicts that the HVAC system would use approximately $23 \%$ more energy than was realized for the year and predicts that non-HVAC electricity use (lights, appliances, plug loads) would be nearly $65 \%$ more than was observed. Overall, the simulation predicted $44 \%$ higher whole-house annual energy consumption than was measured in the home in 2002.

Some investigation was warranted to discover if differences in the standard assumptions and the actual operating conditions could explain this large discrepancy.

Monitored data and the "Adjusted" Building America Prototype. Weather data used for the Hathaway site (TMY2 weather data for Sterling, Virginia) was significantly different than actual weather during February and October of the monitored period.

Based on the monitored data, the "behavior" of the occupants and the operation of the house were adjusted in simulation in the following ways:

- Internal Gains: plug loads were reduced by about $40 \%$ to match the monitored data 
- HVAC Control: thermostat schedules were adjusted monthly to match observed actual setpoints (which were significantly lower in the heating season than assumed). Also, the thermostat schedule accounts for two week-long vacation periods.

- DHW Load: a slight adjustment was made so that the simulated hot-water volume used matched the observed volume.

- Infiltration: The average infiltration was adjusted based on measured data.

When the actual behavior of the Hathaway house occupants and the measured 2002 weather was used to drive the simulation model, the predicted and observed energy use was much closer. The annual total energy use was less than $5 \%$ different between the model results and the monitored data.

The simulation continued to overpredict the energy consumption in some months - especially the winter months. Some of this difference in energy use was explained by the occupants' use of wood to heat the house in the winter months.

Overall, it appears the simulation of the Hathaway prototype building was quite accurate. Differences in the monitored data and the Building America prototype simulation results shown in Figure 33 were mostly a result of differing assumptions regarding occupant behavior and weather rather than inaccuracies in the model of the home.

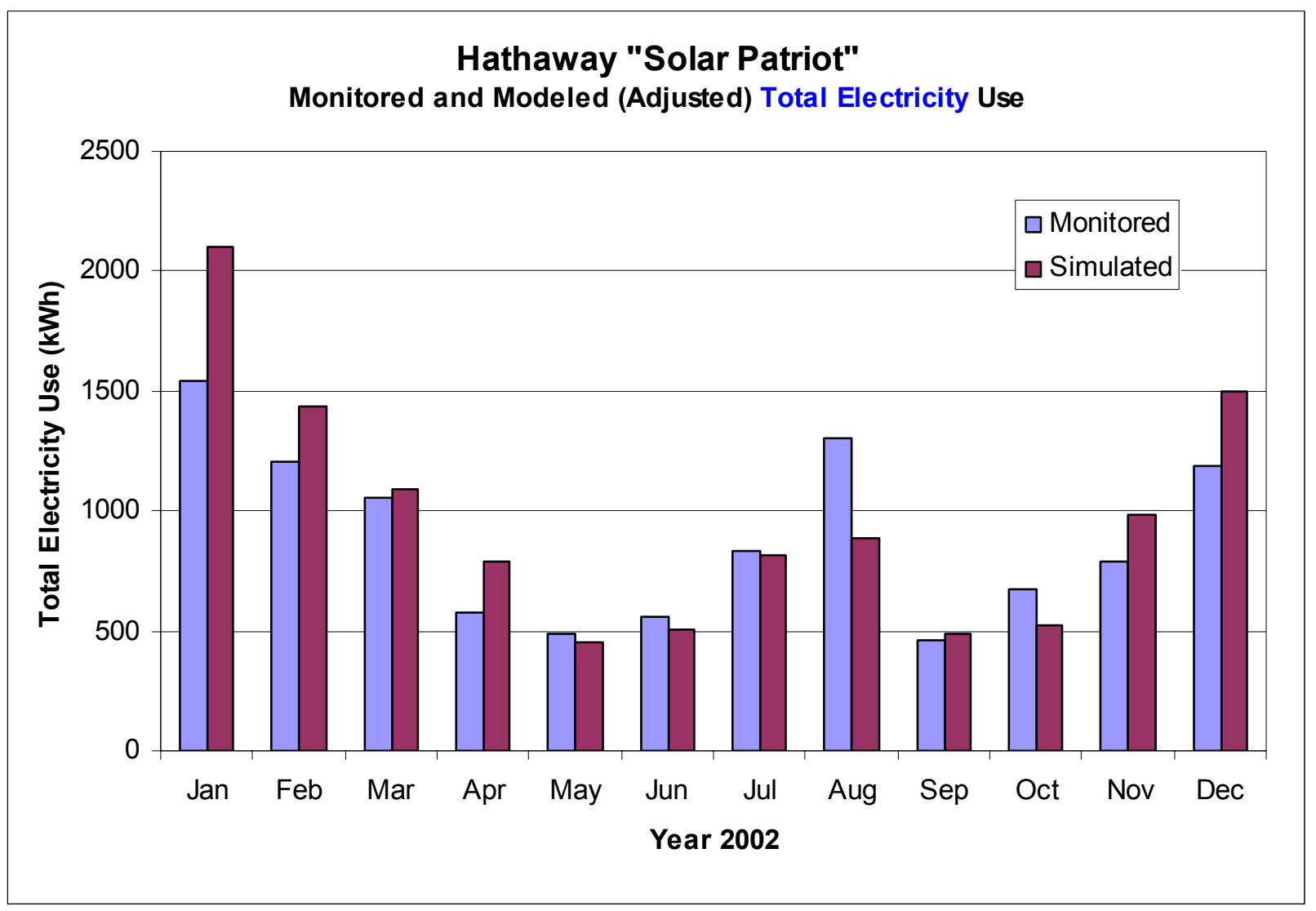

Figure 34. Monitored data vs. the adjusted model results, whole-building energy use 


\subsection{Putting Performance in Context: Simulation Results}

The modeled energy performance of the Hathaway house was compared to two theoretical houses with the same basic architectural features and floor plans. One base case for comparison, called the Regional Standard Practice home, is constructed as a standard new home in the same area as the Hathaway home according to the knowledge and judgment of the authors. The other base case was the Building America Benchmark version 3.1. This Benchmark was designed to represent 1990s typical construction and to be in compliance with the 1995 Model Energy Code (MEC). The basic characteristics of these base case homes are given below:

Regional Standard Practice:

(assumes natural gas is not available on site)

$\begin{array}{ll}\text { Building Shell: } & 2 \times 4 \text { frame walls - R11 fiberglass insulation and wood sheathing } \\ & \text { R30 ceiling insulation } \\ & \text { R7 basement wall insulation } \\ \text { double-pane clear windows with aluminum frames } & \\ & \text { Standard air-infiltration (0.51 ACH average) } \\ & \\ \text { HVAC: } & 6.8 \text { SEER 5-ton air-conditioner } \\ & \text { Electric DHW, } 40 \text { gallons, EF }=0.88\end{array}$

Building America Benchmark 3.1:

(assumes natural gas is not available on site)

\begin{tabular}{|c|c|}
\hline Building Shell: & $\begin{array}{l}2 \times 4 \text { frame walls }- \text { overall } \mathrm{R} \text { factor }=12.2 \\
\mathrm{R} 33.3 \text { ceiling insulation } \\
\mathrm{R} 17 \text { basement wall insulation } \\
\text { double-pane Low } \mathrm{E} \text { windows with } \mathrm{U}=0.40 \\
\text { Standard air-infiltration }(0.51 \mathrm{ACH} \text { average })\end{array}$ \\
\hline HVAC: & $\begin{array}{l}\text { 10 SEER 5-ton air-conditioner } \\
6.8 \mathrm{HSPF} \text { heat pump with electric backup }\end{array}$ \\
\hline DHW: & Electric DHW, 40 gallons, $\mathrm{EF}=0.88$ \\
\hline
\end{tabular}

The Building America program has created a standard set of three output tables that are used with any building modeling effort. The standard output tables for the Hathaway house modeling are given in Tables 8 through 10 . 
Table 8. Summary of End-Use Site Energy

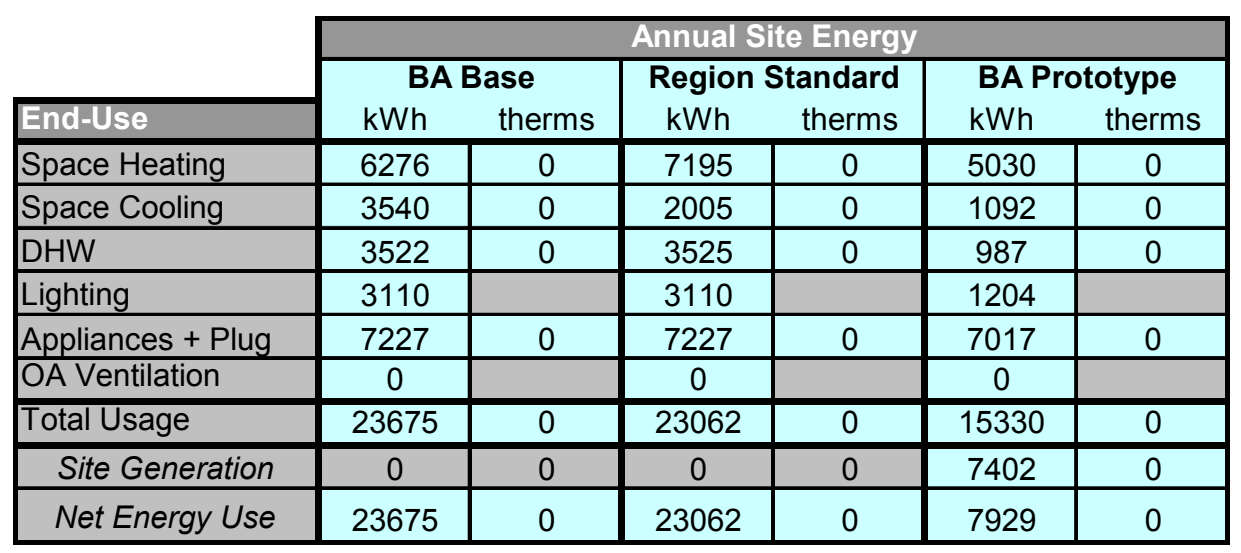

Table 9. Summary of End-Use Source Energy and Savings

\begin{tabular}{|c|c|c|c|c|c|c|c|}
\hline & & & & \multicolumn{4}{|c|}{ Source Energy Savings } \\
\hline & \multicolumn{3}{|c|}{ Annual Source Energy } & \multicolumn{2}{|c|}{ Percent of End-Use } & \multicolumn{2}{|c|}{ Percent of Total } \\
\hline & Base & Region & Proto & BA & Reg & BA & $\operatorname{Reg}$ \\
\hline End-Use & MBTU/yr & MBTU/yr & MBTU/yr & Base & Base & Base & Base \\
\hline Space Heating & 64 & 74 & 52 & $20 \%$ & $30 \%$ & $5 \%$ & $9 \%$ \\
\hline Space Cooling & 36 & 21 & 11 & $69 \%$ & $46 \%$ & $10 \%$ & $4 \%$ \\
\hline DHW & 36 & 36 & 10 & $72 \%$ & $72 \%$ & $11 \%$ & $11 \%$ \\
\hline Lighting & 32 & 32 & 12 & $61 \%$ & $61 \%$ & $8 \%$ & $8 \%$ \\
\hline Appliances + Plug & 74 & 74 & 72 & $3 \%$ & $3 \%$ & $1 \%$ & $1 \%$ \\
\hline OA Ventilation & 0 & 0 & 0 & $0 \%$ & $0 \%$ & $0 \%$ & $0 \%$ \\
\hline Total Usage & 243 & 236 & 157 & $35 \%$ & $34 \%$ & $35 \%$ & $34 \%$ \\
\hline Site Generation & 0 & 0 & -76 & & & $31 \%$ & $32 \%$ \\
\hline Net Energy Use & 243 & 236 & 81 & $67 \%$ & $66 \%$ & $67 \%$ & $66 \%$ \\
\hline
\end{tabular}

Table 10. Energy Savings of Energy Efficiency Measures

\begin{tabular}{|c|c|c|c|c|c|c|c|c|c|c|c|c|c|c|}
\hline \multirow{3}{*}{ Increment } & & & & & \multirow{2}{*}{\multicolumn{3}{|c|}{$\begin{array}{c}\text { National Average } \\
\text { Energy Cost }\end{array}$}} & \multicolumn{7}{|c|}{ Regional Standard (Local Costs) } \\
\hline & \multicolumn{2}{|c|}{ Site Energy } & \multicolumn{2}{|c|}{ Source Energy } & & & & \multicolumn{3}{|c|}{ Energy Cost } & \multirow{2}{*}{\multicolumn{2}{|c|}{$\frac{\text { Measure }}{\text { value }(\$ / y r)}$}} & \multirow{2}{*}{\multicolumn{2}{|c|}{$\begin{array}{l}\text { Package } \\
\text { savings } \$ / y r\end{array}$}} \\
\hline & $\mathrm{kWh}$ & therms & MBTU & Savings $\%$ & & $\$ / y r$ & Savings \% & & $\$ / y r$ & Savings $\%$ & & & & \\
\hline $\begin{array}{l}\text { Base } \\
\text { (Bldg America) }\end{array}$ & 23675 & 0 & 242.6 & & $\$$ & 2,368 & & & 2,332 & & & & & \\
\hline $\begin{array}{l}\text { Base } \\
\text { (Regional Std Practice) }\end{array}$ & 23062 & 0 & 236.3 & $3 \%$ & $\$$ & 2,306 & $3 \%$ & $\$$ & 3,053 & & & & & \\
\hline $\begin{array}{l}\text { Base } \\
\text { (Builder Std Practice) }\end{array}$ & 27851 & 0 & 285.4 & $-18 \%$ & $\$$ & 2,785 & $-18 \%$ & & 2,743 & & & & & \\
\hline $\begin{array}{l}\text { Base }+ \\
\text { improved walls } \\
\end{array}$ & 25642 & 0 & 262.7 & $-8 \%$ & $\$$ & 2,564 & $-8 \%$ & $\$$ & 2,526 & $8 \%$ & $\$$ & 217.6 & $\$$ & 218 \\
\hline $\begin{array}{l}\text { Base ++ } \\
\text { Low-E Windows }\end{array}$ & 23140 & 0 & 237.1 & $2 \%$ & $\$$ & 2,314 & $2 \%$ & $\$$ & 2,279 & $17 \%$ & $\$$ & 246.4 & $\$$ & 464 \\
\hline $\begin{array}{l}\text { Base ++ } \\
\text { Smaller A/C (5 }>4 \text { tons) }\end{array}$ & 22806 & 0 & 233.7 & $4 \%$ & $\$$ & 2,281 & $4 \%$ & & 2,246 & $18 \%$ & $\$$ & 32.9 & $\$$ & 497 \\
\hline $\begin{array}{l}\text { Base ++ } \\
\text { Inc. Bsmt Wall Insulation }\end{array}$ & 22499 & 0 & 230.5 & $5 \%$ & $\$$ & 2,250 & $5 \%$ & $\$$ & 2,216 & $19 \%$ & $\$$ & 30.2 & $\$$ & 527 \\
\hline $\begin{array}{l}\text { Base ++ } \\
\text { Ground Source HP (+DHW) }\end{array}$ & 18380 & 0 & 188.3 & $22 \%$ & $\$$ & 1,838 & $22 \%$ & $\$$ & 1,810 & $34 \%$ & $\$$ & 405.7 & $\$$ & 933 \\
\hline $\begin{array}{l}\text { Base ++ } \\
\text { Solar DHW }\end{array}$ & 17202 & 0 & 176.3 & $27 \%$ & $\$$ & 1,720 & $27 \%$ & $\$$ & 1,694 & $38 \%$ & $\$$ & 116.0 & $\$$ & 1,049 \\
\hline $\begin{array}{l}\text { Base ++ } \\
\text { Lighting, Appl. \& Plug }\end{array}$ & 15330 & 0 & 157.1 & $35 \%$ & $\$$ & 1,533 & $35 \%$ & $\$$ & 1,510 & $45 \%$ & $\$$ & 184.4 & $\$$ & 1,233 \\
\hline Site Generation & & & & & & & & & & & & & & \\
\hline $\begin{array}{l}\text { Base ++ } \\
\text { PV }\end{array}$ & 7928 & 0 & 81.2 & $67 \%$ & $\$$ & 793 & & $\$$ & 781 & $72 \%$ & $\$$ & 729.0 & $\$$ & 1,962 \\
\hline
\end{tabular}




\subsection{What if ... Investigating Possible Improvements}

The Hathaway house reduced total energy use by $35 \%$ as compared to the Building America Benchmark (not including the contribution of the PV system). The energy-use reduction by enduse is given in the second column of Table 11. While impressive in its application of individual technologies, the overall result leaves two-thirds of the energy use untouched.

Lighting and DHW energy use was reduced by a large fraction and was close to the limits of practical energy-saving technologies. The space-conditioning energy use could be reduced further by eliminating some of the heating and cooling loads with more efficient shell technology, as well as by applying even more efficient space-conditioning equipment. The appliance and plug load category was nearly untouched by the energy-reduction measures.

Table 11. Energy Reduction by End-Use Compared to the Building America Benchmark ${ }^{1}$

\begin{tabular}{|l|c|c|}
\hline Category & $\begin{array}{l}\text { Hathaway } \\
\text { Prototype }\end{array}$ & “Super Building” \\
\hline Indoor Lighting & $61 \%$ & $61 \%$ \\
\hline $\begin{array}{l}\text { Appliances and Plug } \\
\text { Loads }\end{array}$ & $3 \%$ & $3 \%$ \\
\hline $\begin{array}{l}\text { Space-Heating } \\
\text { Equipment }\end{array}$ & $20 \%$ & $96 \%$ \\
\hline $\begin{array}{l}\text { Space-Cooling } \\
\text { Equipment }\end{array}$ & $69 \%$ & $89 \%$ \\
\hline DHW Equipment & $72 \%$ & $72 \%$ \\
\hline Exterior Lighting & $71 \%$ & $71 \%$ \\
\hline Total & $\mathbf{3 5 \%}$ & $\mathbf{5 8 \%}$ \\
\hline
\end{tabular}




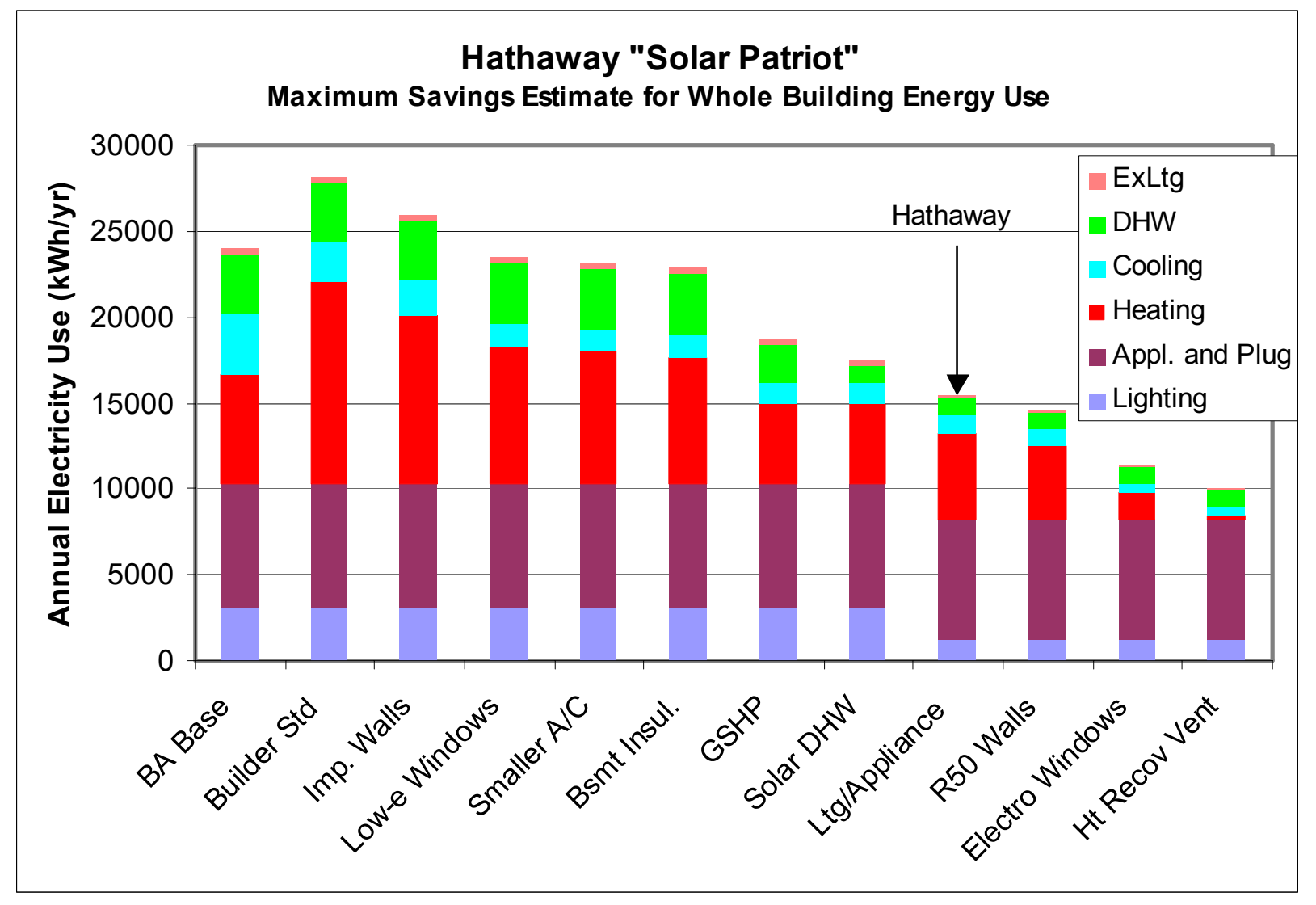

Figure 35. Energy use by end-use category, beyond the Hathaway prototype

Figure 35 shows the change in energy use with each added technology. The column labeled "Ltg/Appliance" is the Hathaway prototype model. The last four columns apply additional technologies in an attempt to reduce the heating and cooling loads as much as practical (and beyond). In the end, the heating, cooling and DHW energy use was reduced to less than 1700 $\mathrm{kWh}$ per year, an $88 \%$ reduction.

The last column in Table 11 shows the energy savings for the "Super House" that includes all the technologies in Figure 35. The application of building shell and other measures currently not cost effective, including super-insulated walls, electrochromic glazing, and highly effective heat recovery ventilation, can eliminate much of the remaining space-conditioning load. However, the appliance and plug loads come to dominate energy consumption and account for nearly $70 \%$ of the total energy use.

This analysis points out that even with highly effective energy-savings technologies (pushed beyond levels currently practical), whole-house energy-use reduction for efficiency measures is only about $60 \%$ without reducing the energy use of appliances and plug loads largely considered outside the designer's jurisdiction. 


\section{Discussion}

The 2020 research goal for the Building America program is to develop cost-effective production-ready homes that achieve zero net energy. The Hathaway house is an early example of a home on the path to zero net energy. A zero net energy home is one that produces on-site as much energy as it consumes on an annual basis. The goal of this home was to achieve zero energy. Through energy efficiency and solar energy the home achieved remarkable performance - reducing its whole house energy needs $35 \%$ and meeting nearly $70 \%$ of the remaining electricity needs with solar electricity.

\subsection{On the Path to Zero Net Energy}

The Hathaway case study provides many insights into the path to commercially viable zero energy homes. It also raises more questions than it answers.

It is clear that modeling tools will be required to sift through the many options for approaching zero energy and choose the options that achieve the goal as cost effectively as possible for the climate zone and builder preferences. The target is most certainly not a singularity but a spectrum of options. For example, many different shell designs such as wood frame, structural insulated panels, insulated concrete forms, and others may be parallel paths to the zero energy goal. The most appropriate path may depend on costs, local codes, local material availability, builder preferences, and market preferences. Similar parallels exist in equipment strategies.

The zero energy home design approach will likely employ typical occupant behavior assumptions and typical annual weather data. A home designed to consume zero net energy under these assumptions may be a net consumer or a net producer with any real occupants in any specific year. In fact it could easily be a net producer one year and a net consumer the next. The task of the designer is to evaluate the range of possible home construction details near the economically optimum design and choose one most appropriate for the circumstances. Hence the design will be a combination of science and art.

A tool, call the Building Energy Optimization (BEopt) program is currently under development at NREL. This tool will allow researchers to choose possible shell and equipment options and automatically run hundreds or thousands of hourly building energy simulations to identify the lowest cost combinations to achieve a given energy savings goal for a specific home geometry in a specific location. The program is being designed to allow the user to investigate not only the optimal design, but also designs that are near the optimal.

The Hathaway house did not have the advantage of energy modeling during the design phase and yet achieved impressive energy efficiency. Subsequent analyses indicate that a more efficient shell to reduce space-conditioning loads would have brought the home closer to its zero energy goals. However, even with efficient lighting and appliances, the lights and appliance and plug loads were a significant energy consumer. About $4 \mathrm{~kW}$ of PV were required to meet the needs of these loads alone. To achieve the zero energy goal with no further efficiency increases, the Hathaway house would need about $2.6 \mathrm{~kW}$ of PV in addition to the $6.0 \mathrm{~kW}$ it had during this study. 


\subsection{Systems Operations and Interactions}

The Hathaway house included several advanced systems including PVs, solar water heating, and a ground-coupled heat pump. The PV system worked well during the monitoring period consistently delivering the expected performance with no maintenance issues. In May 2002 the power output of one of the PV inverters was interrupted when the homeowner inadvertently threw a fuse during a tour. We noticed the drop in power in the data, informed the homeowner, and the power was quickly restored. This in an advantage of monitoring home performance, but it also raises the question of how long it would take an average homeowner to notice if their PV system was not operating properly.

The ground-coupled heat pump also performed well throughout the monitoring period with an average heating COP of 3.6 and cooling COP of 3.2. System performance data from the manufacturer list a COP of about 4.1 for heating for a horizontal tube field and a ground temperature of $55^{\circ} \mathrm{F}$. The average water-heating COP of the system was about 1.55, which is similar to dedicated air-source heat-pump water heaters. Early in the project, the water-heating energy for the household was much higher than expected. In talking with the Hathaways, we learned that they switched the heat pump to heat the water in the storage tank until well after their morning hot water draws. Because the tank was now hot at the beginning of the day, the solar water-heating system operated at a very low efficiency. The situation was corrected by adding a timer to the water heating mode of the heat pump. The time was set to top off the tank temperature before the morning hot water draws. The morning use of hot water then left the tank filled with cooler water and the solar water heater operated much more effectively. The overall energy use for water heating dropped dramatically when this strategy was implemented in November 2001 (Figure 14).

Although the heat pump worked well, the overall energy performance of the space-conditioning system was reduced because of high air-handler fan energy consumption. The air handler consumed more than $25 \%$ as much energy as the heat pump. This was a result of two factors: the occupants sometimes ran the air-handler fan when the heat pump was not operating to mix the air in the home, and the air handler did not use an efficient ECM motor.

\subsection{Modeling and Monitoring Approach}

We use a combination of computer modeling, testing, and monitoring to understand the performance of prototype houses. As a Building America project, the performance of a home is required to be measured against the Building America Benchmark home. The benchmark home is based on construction practices of the mid-1990s. To make the comparison, the prototype home and the matching benchmark home must be modeled to compare their energy performance. Therefore, modeling is an essential tool to track the progress of homes toward the Building America program goals for energy savings.

Computer models provide other useful information that cannot be gained by testing or monitoring. The model provides generalized energy performance of a home; performance that is based on average occupancy behavior and typical weather patterns. In contrast, monitoring provides information on the performance of the home with specific occupants and actual weather conditions. The model can also be used to generate "what-if" scenarios (as discussed in section 5.3) to see how the home would perform if it incorporated different building techniques and 
energy technologies. These attributes make the model a powerful tool for understanding the performance of the home. So why not just create a computer model and skip testing and monitoring?

Testing and monitoring data increase confidence in the computer model. There are some areas, such as shell leakage or performance of newly developed equipment, that are difficult to know in advance and, therefore, difficult to accurately model. In these cases, the measurements become input to the model and improve its accuracy. Measurements also provide a reality check for the computer simulation. If the simulation can accurately predict the behavior of the home given the measured inputs, it again increases our confidence in the model. Finally, testing and modeling provide information on home performance that modeling cannot provide. Testing and monitoring provides quick feedback on the performance of new technologies. It provides insights into equipment installation issues, interaction between occupants and technology, and occupant behavior. It can also provides the means to interpret higher level results such as energy bill comparison.

Modeling, testing, and monitoring nicely complement each other and provide different insights into the performance of the home. We have found that a combination of them tailored to the objectives of the project is the best approach to understanding advanced homes. 


\section{References}

${ }^{1}$ Hendron, B., et. al., 2004, Building America Research Benchmark Definition, Version 3.1, NREL/TP-550-36429, Golden, CO: National Renewable Energy Laboratory

${ }^{2}$ World Population Prospects: The 2002 Revision, February 2003, ESA/P/WP.180, United Nations Population Division.

${ }^{3}$ United States Energy Information Administration, see http://www.eia.gov/.

${ }^{4}$ Rastelli, Linda, Jan/Feb 2002, "Energy Independence-With all the Comforts," Solar Today, Boulder, CO: American Solar Energy Society, Vol. 16, No. 1.

${ }^{5}$ Sklar, Scott, Sept/Oct 2001, "Solar House Goes to Washington," Home Energy Magazine, Berkeley, CA.

${ }^{6}$ Home Buyer Publications, Inc., Mar/Apr 2001, "Solar Patriot on Parade on the National Mall," Building Systems Magazine, Lakewood, CO.

7 “Solar Home add to Earth Day landscape," April 18, 2001, Environmental News Network, www.enn.com.

${ }^{8}$ For more information on the Building Energy Program of the Department of Energy see www.eere.energy.gov/buildings

${ }^{9}$ For more information on the Center for Buildings and Thermal Systems at the National Renewable Energy Laboratory see www.nrel.gov/buildings thermal

${ }^{10}$ This program no longer exists as a separate entity. It is part of the Building America program. For more information on the current research pertaining to zero energy homes see www.buildingamerica.gov.

${ }^{11}$ For more information on the Building America Program see www.buildingamerica.gov

12 Klein, S., et al., 1996, TRNSYS: A Transient System Simulation Program - Reference Manual, Solar Energy Laboratory, University of Wisconsin.

${ }^{13}$ American Society of Heating, Refrigeration and Air Conditioning Engineers, 2004, Ventilation and Acceptable Indoor Air Quality in Low-Rise Residential Buildings, Fourth Public Review, ASHRAE Standard 62.2, Atlanta, GA: American Society of Heating, Refrigeration and Air Conditioning Engineers.

${ }^{14}$ Lawrence Berkeley National Laboratory, DOE2.2 Building Simulation Software, Berkeley, CA: Lawrence Berkeley National Laboratory. available at http://www.osti.gov/estsc/ or http://www.doe2.com

15 Judkoff, R., and Neymark, J., 1995, International Energy Agency Building Energy Simulation Test (BESTEST) and Diagnostic Method, NREL/TP-472-6231, Golden, CO: National Renewable Energy Laboratory.

${ }^{16}$ Judkoff, R., and Neymark, J. Home Energy Rating System Building Energy Simulation Test (HERS BESTEST) Volumes 1 and 2, Nov 1995, NREL/TP-472-7332. 


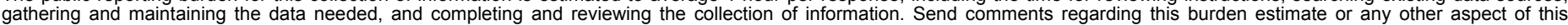

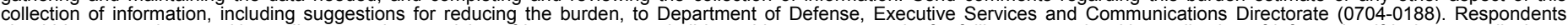

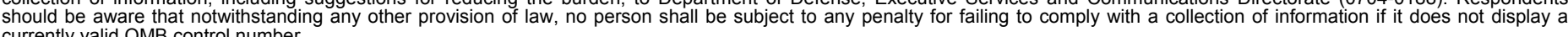

PLEASE DO NOT RETURN YOUR FORM TO THE ABOVE ORGANIZATION.
1. REPORT DATE (DD-MM-YYYY) May 2005

\section{REPORT TYPE \\ Technical Report}
4. TITLE AND SUBTITLE
The Hathaway "Solar Patriot" House: A Case Study in Efficiency and Renewable Energy

3. DATES COVERED (From - To)

5a. CONTRACT NUMBER

DE-AC36-99-GO10337

5b. GRANT NUMBER

5c. PROGRAM ELEMENT NUMBER

5d. PROJECT NUMBER

NREL/TP-550-37731

5e. TASK NUMBER

BET5.8004

5f. WORK UNIT NUMBER
7. PERFORMING ORGANIZATION NAME(S) AND ADDRESS(ES)

National Renewable Energy Laboratory

1617 Cole Blvd.

Golden, CO 80401-3393
8. PERFORMING ORGANIZATION REPORT NUMBER

NREL/TP-550-37731

9. SPONSORING/MONITORING AGENCY NAME(S) AND ADDRESS(ES)

10. SPONSOR/MONITOR'S ACRONYM(S) NREL

11. SPONSORING/MONITORING AGENCY REPORT NUMBER

12. DISTRIBUTION AVAILABILITY STATEMENT

National Technical Information Service

U.S. Department of Commerce

5285 Port Royal Road

Springfield, VA 22161

\section{SUPPLEMENTARY NOTES}

\section{ABSTRACT (Maximum 200 Words)}

This report details the monitored and modeled performance of a solar home outside of Washington, D.C. We modeled the home energy performance using DOE2.2, performed numerous short-terms tests on the home and monitored its occupied performance for 29 months. The home uses modular construction, solar water heating, a ground-coupled heat pump, efficient appliances and compact fluorescent lighting to reduce its energy consumption by $35 \%$ compared to the Building America research benchmark home. The addition of $6 \mathrm{~kW}$ of photovoltaics increases the savings to $67 \%$ compared to the Building America research benchmark. A more efficient shell to reduce space conditioning loads would have brought the home closer to its zero energy goals. However, even with efficient lighting and appliances, the lights, appliance and plug loads are a significant energy consumer. About $4 \mathrm{~kW}$ of PV are required to meet the needs of these loads alone. To achieve the zero energy goal with no further efficiency increases, the Hathaway house would need about $2.6 \mathrm{~kW}$ of PV in addition to the $6.0 \mathrm{~kW}$ it now has.

\section{SUBJECT TERMS}

Building America; DOE2.2; solar home; solar patriot; hathaway house; energy performance; case study; PV; photovoltaics

\begin{tabular}{|c|c|c|c|c|}
\hline \multicolumn{3}{|c|}{ 16. SECURITY CLASSIFICATION OF: } & \multirow{2}{*}{$\begin{array}{l}\text { 17. LIMITATION } \\
\text { OF ABSTRACT } \\
\text { UL }\end{array}$} & \multirow{2}{*}{$\begin{array}{l}\text { 18. NUMBER } \\
\text { OF PAGES }\end{array}$} \\
\hline $\begin{array}{l}\text { a. REPORT } \\
\text { Unclassified }\end{array}$ & $\begin{array}{l}\text { b. ABSTRACT } \\
\text { Unclassified }\end{array}$ & $\begin{array}{l}\text { c. THIS PAGE } \\
\text { Unclassified }\end{array}$ & & \\
\hline
\end{tabular}

19a. NAME OF RESPONSIBLE PERSON

19b. TELEPHONE NUMBER (Include area code) 


\section{A Strong Energy Portfolio for a Strong America}

Energy efficiency and clean, renewable energy will mean a stronger economy, a cleaner environment, and greater energy independence for America. Working with a wide array of state, community, industry, and university partners, the U.S. Department of Energy's Office of Energy Efficiency and Renewable Energy invests in a diverse portfolio of energy technologies.

\section{Research and Development of Buildings}

Our nation's buildings consume more energy than any other sector of the U.S. economy, including transportation and industry. Fortunately, the opportunities to reduce building energy useand the associated environmental impacts-are significant.

DOE's Building Technologies Program works to improve the energy efficiency of our nation's buildings through innovative new technologies and better building practices. The program focuses on two key areas:

\section{- Emerging Technologies} Research and development of the next generation of energy-efficient components, materials, and equipment

- Technology Integration Integration of new technologies with innovative building methods to optimize building performance and savings

For more information contact: EERE Information Center 1-877-EERE-INF (1-877-337-3463) www.eere.energy.gov

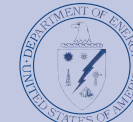

U.S. Department of Energy Energy Efficiency and Renewable Energy

An electronic copy of this publication is available on the Building America Web site at www.buildingamerica.gov

\section{Visit our Web sites at:}

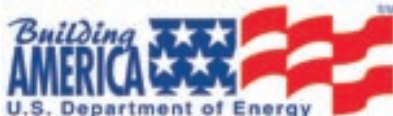

Building America Program

George S. James• New Construction • 202-586-9472・ fax: 202-586-8134・e-mail: George.James@ee.doe.gov

Terry Logee • Existing Homes • 202-586-1689 • fax: 202-586-4617• e-mail: terry.logee@ee.doe.gov Lew Pratsch • Integrated Onsite Power • 202-586-1512 • fax: 202-586-8185 • e-mail: Lew.Pratsch@hq.doe.gov Building America Program • Office of Building Technologies, EE-2J • U.S. Department of Energy $\bullet 1000$ Independence Avenue, S.W. $\bullet$ Washington, D.C. 20585-0121・ www.buildingamerica.gov

Building Industry Research Alliance (BIRA)

Robert Hammon • ConSol • 7407 Tam 0'Shanter Drive \#200 • Stockton, CA 95210-3370 • 209-473-5000 • fax: 209-474-0817• e-mail: Rob@consol.ws•www.bira.ws

Building Science Consortium (BSC)

Betsy Pettit • Building Science Consortium (BSC) • 70 Main Street • Westford, MA 01886 • 978-589-5100 • fax: 978-589-5103• e-mail: Betsy@buildingscience.com • www.buildingscience.com

Consortium for Advanced Residential Buildings (CARB)

Steven Winter • Steven Winter Associates, Inc. 50 Washington Street • Norwalk, CT 06854 • 203-857-0200 • fax: 203-852-0741 • e-mail: swinter@swinter.com•www.carb-swa.com

\section{Davis Energy Group}

David Springer • Davis Energy Group • 123 C Street • Davis, CA 95616 • 530-753-1100 • fax: 530-753-4125 • e-mail: springer@davisenergy.com • deg@davisenergy.com・ www.davisenergy.com/index.html

\section{IBACOS Consortium}

Brad Oberg •IBACOS Consortium • 2214 Liberty Avenue • Pittsburgh, PA $15222 \bullet 412-765-3664 \bullet$ fax: 412-765-3738 • e-mail: boberg@ibacos.com • www.ibacos.com

Industrialized Housing Partnership (IHP)

Subrato Chandra • Florida Solar Energy Center • 1679 Clearlake Road • Cocoa, FL 32922 • 321-638-1412 • fax: 321-638-1439 • e-mail: subrato@fsec.ucf.edu • www.baihp.org

National Association of Home Builders (NAHB) Research Center

Tom Kenney • National Association of Home Builders (NAHB) Research Center $\bullet 400$ Prince George's Boulevard • Upper Marlboro, MD 20774 • 301-430-6246 • fax: 301-430-6180 • toll-free: 800-638-8556 • www.nahbrc.org/

\section{National Renewable Energy Laboratory}

Ren Anderson • 1617 Cole Boulevard, MS-2722 • Golden, C0 80401 • 303-384-7433 • fax: 303-384-7540 •

e-mail: ren_anderson@nrel.gov • www.nrel.gov

Tim Merrigan • 1617 Cole Boulevard, MS-2722 • Golden, C0 80401 • 303-384-7349 • fax: 303-384-7540 • e-mail: tim_merrigan@nrel.gov • www.nrel.gov

\section{Oak Ridge National Laboratory}

Pat M. Love • P.0. Box $2008 \bullet$ One Bethel Valley Road • Oak Ridge, TN 37831 • 865-574-4346• fax: 865-574-9331 • e-mail: lovepm@ornl.gov・www.ornl.gov

Produced for the U.S. Department of Energy (DOE) by the National Renewable Energy Laboratory, a DOE national laboratory. May $2005 \bullet$ NREL/TP-550-37731

Printed with a renewable-source ink on paper containing at least 50\% wastepaper, including $20 \%$ postconsumer waste. 